\title{
Subsurface and Petroleum Geology of the Southwestern Santa Clara Valley ("Silicon Valley"), California
}

Professional Paper 1663

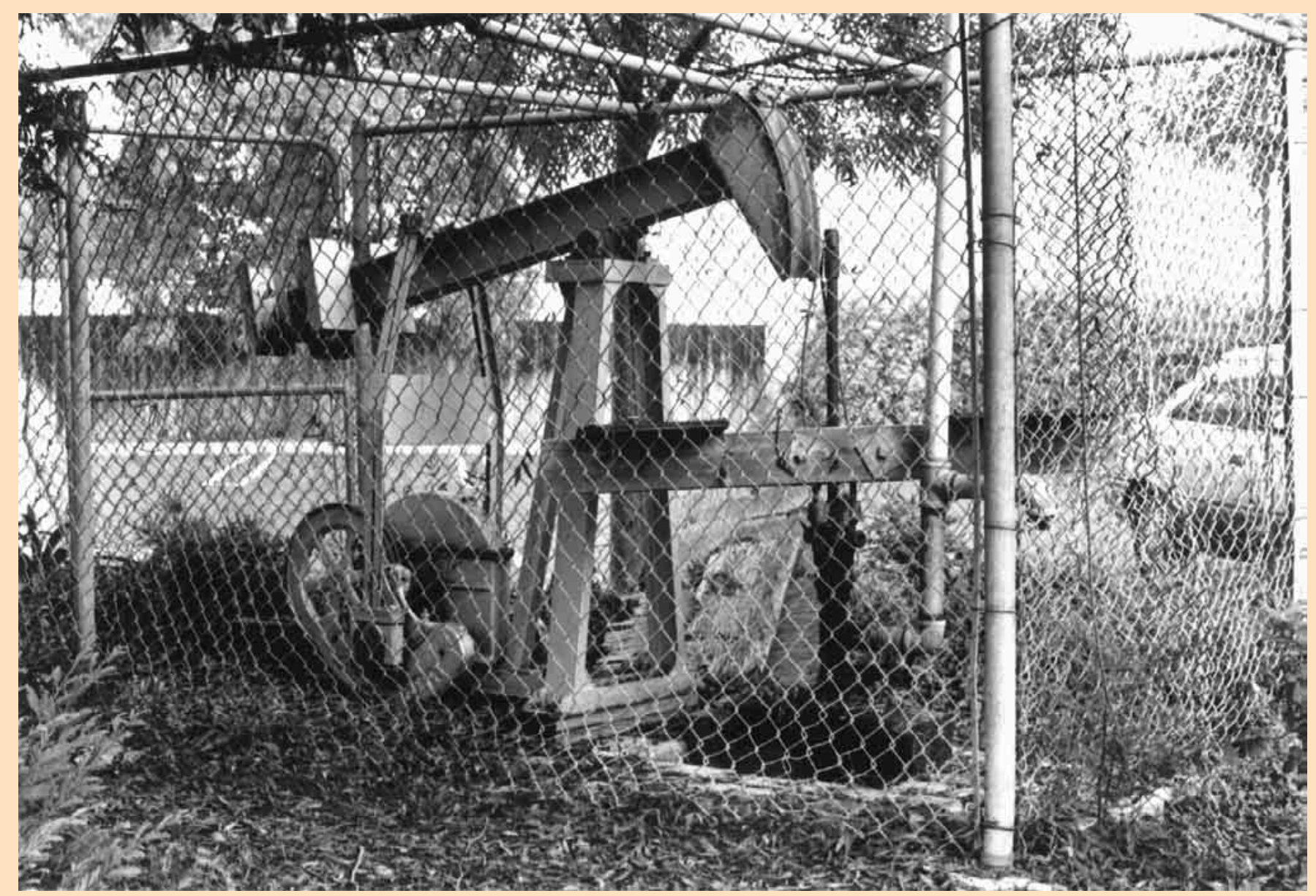

U.S. Department of the Interior

U.S. Geological Survey 


\section{Subsurface and Petroleum Geology of the Southwestern Santa Clara Valley ("Silicon Valley"), California}

By Richard G. Stanley, Robert C. Jachens, Paul G. Lillis, Robert J. McLaughlin, Keith A. Kvenvolden, Frances D. Hostettler, Kristin A. McDougall, and Leslie B. Magoon

Professional Paper 1663 


\title{
U.S. Department of the Interior \\ Gale A. Norton, Secretary
}

\author{
U.S. Geological Survey \\ Charles G. Groat, Director
}

Any use of trade, product, or firm names in this publication is for descriptive purposes only and does not imply endorsement by the U.S. Government.

United States Government Printing Office: 2002

For additional copies please contact:

USGS Information Services

Box 25286

Denver, CO 80225

This report and any updates to it are available online at http://geopubs.wr.usgs.gov/prof-paper/pp1663/

Additional USGS publications can be found online at http://geology.usgs.gov/products.html

For more information about the USGS and its products:

Telephone: 1-888-ASK-USGS

World Wide Web: http://www.usgs.gov/

Text edited by George A. Havach

Layout and design by Stephen L. Scott

Manuscript approved for publication, February 25, 2002

Cataloging-in-Publication data is on file with the Library of Congress

FRONT COVER

Photograph of pump unit atop an oil well in Los Gatos, Calif. The pump unit and well are in a fenced enclosure in the parking lot of a commercial office building on Los Gatos Boulevard near Garden Lane. According to the current owner, the well has not produced oil for many years, but unconfirmed reports suggest that the well yielded about 8 barrels of oil per day in 1953. Geologic and organic-geochemical information from this and other historical oil wells in the Los Gatos area provide important insights into the subsurface geology and geologic history of the southwestern Santa Clara Valley ("Silicon Valley"); see text for further discussion. 


\section{CONTENTS}

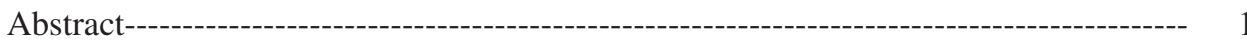

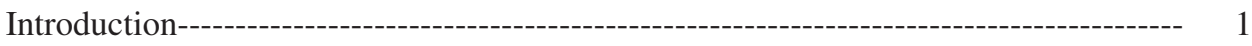

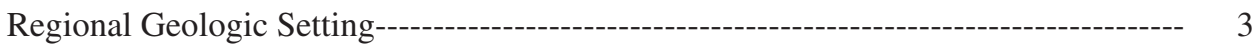

Stratigraphy-------------- 5

Franciscan Complex, Coast Range Ophiolite, Lower Part of the Great Valley

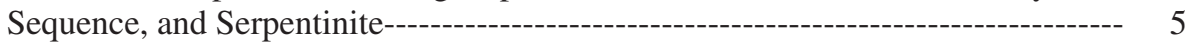

Upper Cretaceous to Eocene Strata---------------------------------------------- 6

Miocene Strata------_-

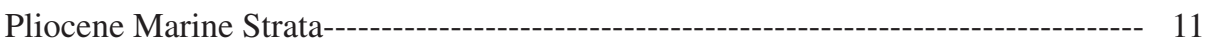

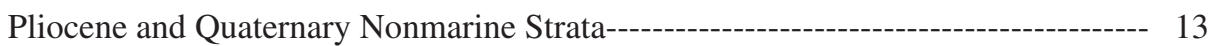

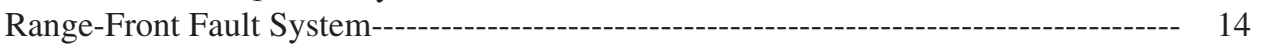

Gravity Evidence for a Concealed Sedimentary Basin Beneath the Southwestern

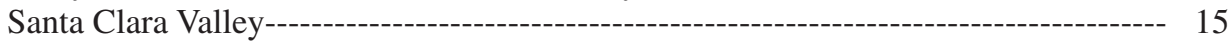

Oil Exploration in the Los Gatos Area------------------------------------------- 15

Forstner's Map--------------------------------------------------------------- 16

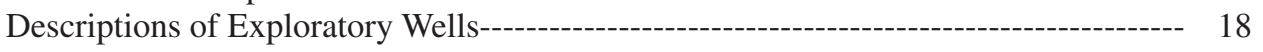

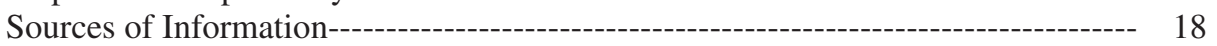

Wells Drilled on the H.H. Main Property------

Orchard Crude Oil Co. Well No. 4--

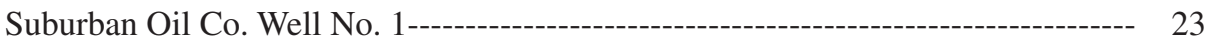

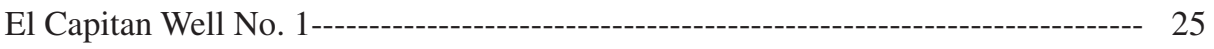

Roanoke Oil Co. Well No. 1---_- 25

T.A.P. Oil Co. Well No. 1----_---_-- 25

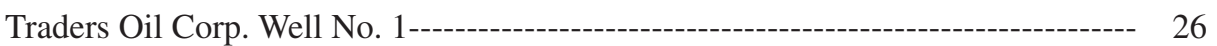

Traders Oil Corp. Well No. 2----------------------------------------------------- 26

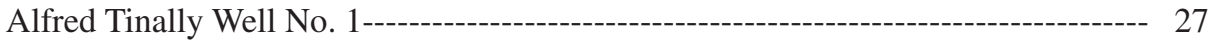

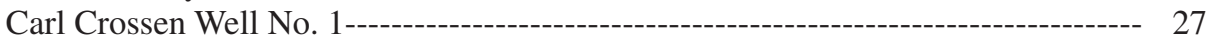

Louise S. and Harold J. Bowen Well No. 1-------------------------------------- 27

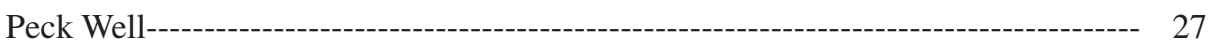

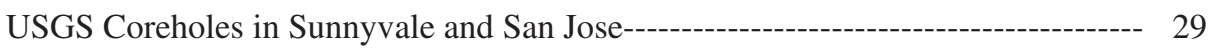

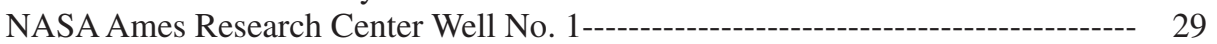

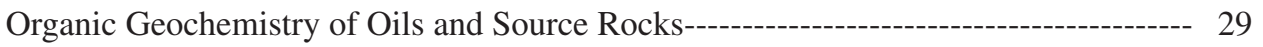

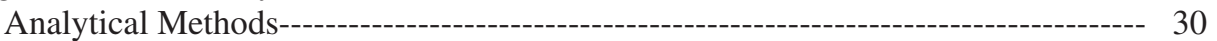

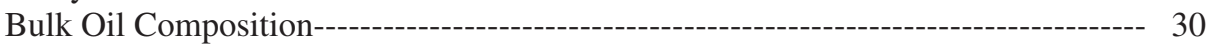

Biomarkers---------------------------------------------------------------------------- 30

Stable-C-Isotopic Composition---------------------------------------------------- 31

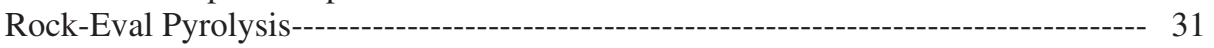

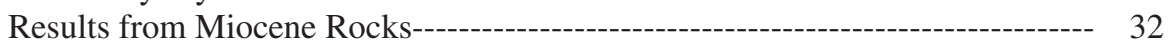

Possible Sources of Oil in the New Almaden Area---------------------------- 34

Depth to the Top of the Oil-Generative Window in the Southwestern Santa Clara Valley------------------------------------------------------- 35

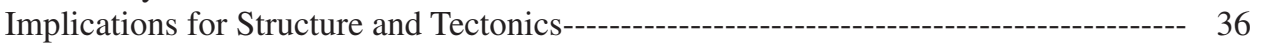

Faulted-Syncline Interpretation------_--- 37

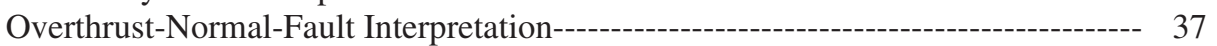

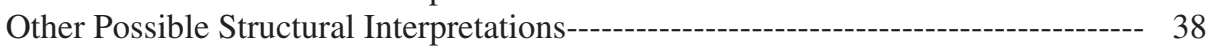

Implications for Petroleum Resources-------------------- 38

Evidence for a Petroleum-Bearing Sedimentary Basin Beneath the Southwestern

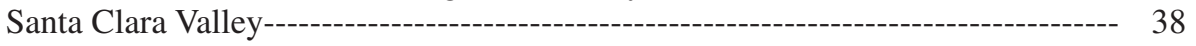

Estimate of the Volume of Oil Generated Beneath the Southwestern Santa Clara

Valley-------- 39

Undiscovered Oil Resources Beneath the Southwestern Santa Clara Valley--------- 40

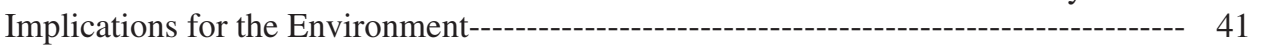

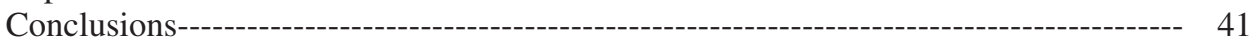

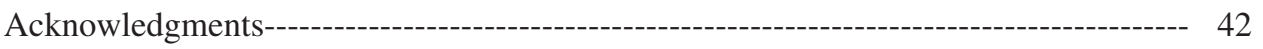

References Cited--------------------------------------------------------------- 42

Appendix: Descriptions of Sample Localities in Miocene Sedimentary Rocks,

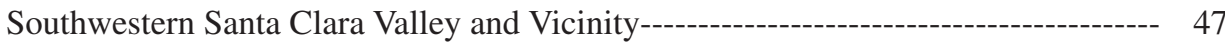




\section{FIGURES}

1. Map of the San Francisco Bay region, California--------

2. Generalized geologic map of the southwestern Santa Clara Valley and vicinity, California---- 3

3. Stratigraphic chart correlating Mesozoic and Cenozoic rock units in the southwestern Santa Clara Valley, and vicinity, California---

4. Sketch map of part of the southwestern Santa Clara Valley and vicinity, California---------- 6

5. Generalized geologic map of the Los Gatos area, southwestern Santa Clara Valley and vicinity, California---------- 10

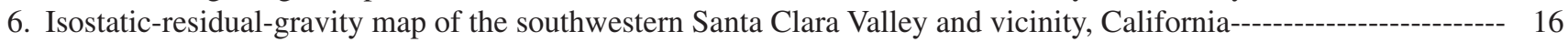

7. Thickness map of low-density Cenozoic deposits in the southwestern Santa Clara Valley and vicinity, California--- 17

8. Part of an unpublished map of the Los Gatos area by W. Forstner-- 19

9. Generalized stratigraphic columns of T.A.P. Oil Co. Well No. 1, Main Estate Well No. 1, Suburban Oil Co. Well No. 1, and Traders Oil Corp. Wells No. 1 and 2---

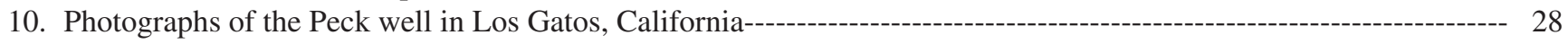

11. Mass chromatograms of oil from the Peck well and from the New Almaden area---- 32

12. Plot of aromatic- versus saturated-hydrocarbon stable-C-isotopic compositions of oil and bitumen samples from the southwestern Santa Clara Valley, California---

13. Modified van Krevelen diagram showing idealized kerogen types and results for samples of Miocene marine shale and mudstone from the southwestern Santa Clara Valley, California--------------------------------- 35

14. Schematic diagrams showing two possible structural interpretations of the Los Gatos area----------------------- 37

\section{TABLES}

1. Exploratory oil wells in the southwestern Santa Clara Valley, Calif., listed in approximate order of drilling-------- 7

2. Age-diagnostic taxa, ages, and paleobathymetry of benthic foraminifers from outcrop samples of Miocene marine sedimentary strata in the southwestern Santa Clara Valley and vicinity, California--------------------- 12

3. Lithologic logs of oil wells in the Los Gatos area, southwestern Santa Clara Valley, California------------------ 52

4. Rock-Eval pyrolysis data on outcrop samples of Miocene marine shale and mudstone from the southwestern Santa Clara Valley and vicinity, California-

5. Rock-Eval pyrolysis data on outcrop samples of the Cretaceous Calera Limestone of the Permanente terrane of

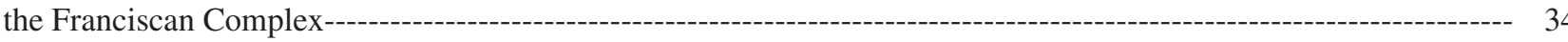

6. Rock-Eval parameters describing petroleum-generative potential---o---o--- 35

7. Rock-Eval parameters describing types of hydrocarbon generated---

8. Organic-geochemical parameters describing level of thermal maturation------------------------------------- 36

9. Estimated subsurface temperatures in the Los Gatos area, southwestern Santa Clara Valley, California------------- 36 


\title{
Subsurface and Petroleum Geology of the Southwestern Santa Clara Valley ("Silicon Valley"), California
}

\author{
By Richard G. Stanley, Robert C. Jachens, Paul G. Lillis, Robert J. McLaughlin, \\ Keith A. Kvenvolden, Frances D. Hostettler, Kristin A. McDougall, \\ and Leslie B. Magoon
}

\section{Abstract}

Gravity anomalies, historical records of exploratory oil wells and oil seeps, new organic-geochemical results, and new stratigraphic and structural data indicate the presence of a concealed, oil-bearing sedimentary basin beneath a highly urbanized part of the Santa Clara Valley, Calif. A conspicuous isostatic-gravity low that extends about $35 \mathrm{~km}$ from Palo Alto southeastward to near Los Gatos reflects an asymmetric, northwest-trending sedimentary basin comprising low-density strata, principally of Miocene age, that rest on higher-density rocks of Mesozoic and Paleogene(?) age. Both gravity and well data show that the low-density rocks thin gradually to the northeast over a distance of about 10 $\mathrm{km}$. The thickest (approx $4 \mathrm{~km}$ thick) accumulation of lowdensity material occurs along the basin's steep southwestern margin, which may be controlled by buried, northeast-dipping normal faults that were active during the Miocene. Movement along these hypothetical normal faults may been contemporaneous (approx 17-14 Ma) with sedimentation and local dacitic and basaltic volcanism, possibly in response to crustal extension related to passage of the northwestwardmigrating Mendocino triple junction. During the Pliocene and Quaternary, the normal faults and Miocene strata were overridden by Mesozoic rocks, including the Franciscan Complex, along northeastward-vergent reverse and thrust faults of the Berrocal, Shannon, and Monte Vista Fault zones. Movement along these fault zones was accompanied by folding and tilting of strata as young as Quaternary and by uplift of the modern Santa Cruz Mountains; the fault zones remain seismically active. We attribute the Pliocene and Quaternary reverse and thrust faulting, folding, and uplift to compression caused by local San Andreas Fault tectonics and regional transpression along the Pacific-North American Plate boundary.

Near the southwestern margin of the Santa Clara Valley, as many as 20 exploratory oil wells were drilled between 1891 and 1929 to total depths as great as $840 \mathrm{~m}$. At least one pump unit is still standing. Although no lithologic or paleontologic samples are available from the wells, driller's $\log$ indicate the presence of thick intervals of brown shale and sandstone resembling nearby outcrops of the Miocene Monterey Formation. Small amounts of oil and gas were observed in several wells, but commercial production was never established. Oil from the Peck well in Los Gatos is highly biodegraded, contains biomarkers commonly found in oils derived from the Monterey Formation, and has a stableC-isotopic $\left(\delta^{13} \mathrm{C}\right)$ composition of -23.32 permil, indicating derivation from a Miocene Monterey Formation source rock. Preliminary calculations suggest that about 1 billion barrels of oil may have been generated from source rocks within the Monterey Formation in the deepest part of the subsurface sedimentary basin between Los Gatos and Cupertino. Most of this oil was probably lost to biodegradation, oxidation, and leakage to the surface, but some oil may have accumulated in as-yet-undiscovered structural and stratigraphic traps along the complex structural boundary between the Santa Clara Valley and the Santa Cruz Mountains. Although some of these undiscovered accumulations of oil may be of commercial size, future petroleum exploration is unlikely because most of the area is currently devoted to residential, recreational, commercial, and industrial uses.

\section{Introduction}

The Santa Clara Valley is a densely populated, highly industrialized area within the southern San Francisco Bay region of California (figs. 1, 2). This area, which is home to more than 1.5 million people, is known throughout the world as Silicon Valley for its leadership in the design and production of computers, electronics, and other high technology.

Much less celebrated is the fact that, about 100 years ago, the southwestern Santa Clara Valley was the location of a minor oil-drilling boom. Between 1891 and 1929, about 20 wells were drilled in the search for petroleum, mostly in Los Gatos. Although only small amounts of oil and gas were detected, long-forgotten logs and other information from the wells provide important clues to the deep subsurface geology of the Santa Clara Valley, which until now has been poorly understood.

This report summarizes our investigation of the subsurface and petroleum geology of the southwestern Santa Clara Valley, using (1) available data from historical exploratory oil wells and oil seeps, (2) new interpretations of isostatic-gravity anomalies and aeromagnetic surveys, (3) new organicgeochemical analyses of oil and potential petroleum-source rocks, and (4) new stratigraphic and structural information 
from outcrops along the valley margin. The results demonstrate that the southwestern Santa Clara Valley is underlain by a concealed, oil-bearing sedimentary basin consisting largely of Miocene marine sedimentary rocks (including the Monterey Formation) that, in places, are more than $3 \mathrm{~km}$ thick. The new data are consistent with the hypothesis that Miocene strata in the southwestern Santa Clara Valley were deposited during an early to middle Miocene episode of normal faulting, volcanism, and crustal extension and subsequently deformed by the Pliocene and Quaternary compression, folding, and thrust faulting which accompanied uplift of the modern Santa Cruz Mountains. Furthermore, these new data imply that about 1 billion barrels of oil may have been generated from Miocene source rocks in the basin and that small accumulations of oil may be present in anticlinal and fault traps along the southwestern margin of the Santa Clara Valley.

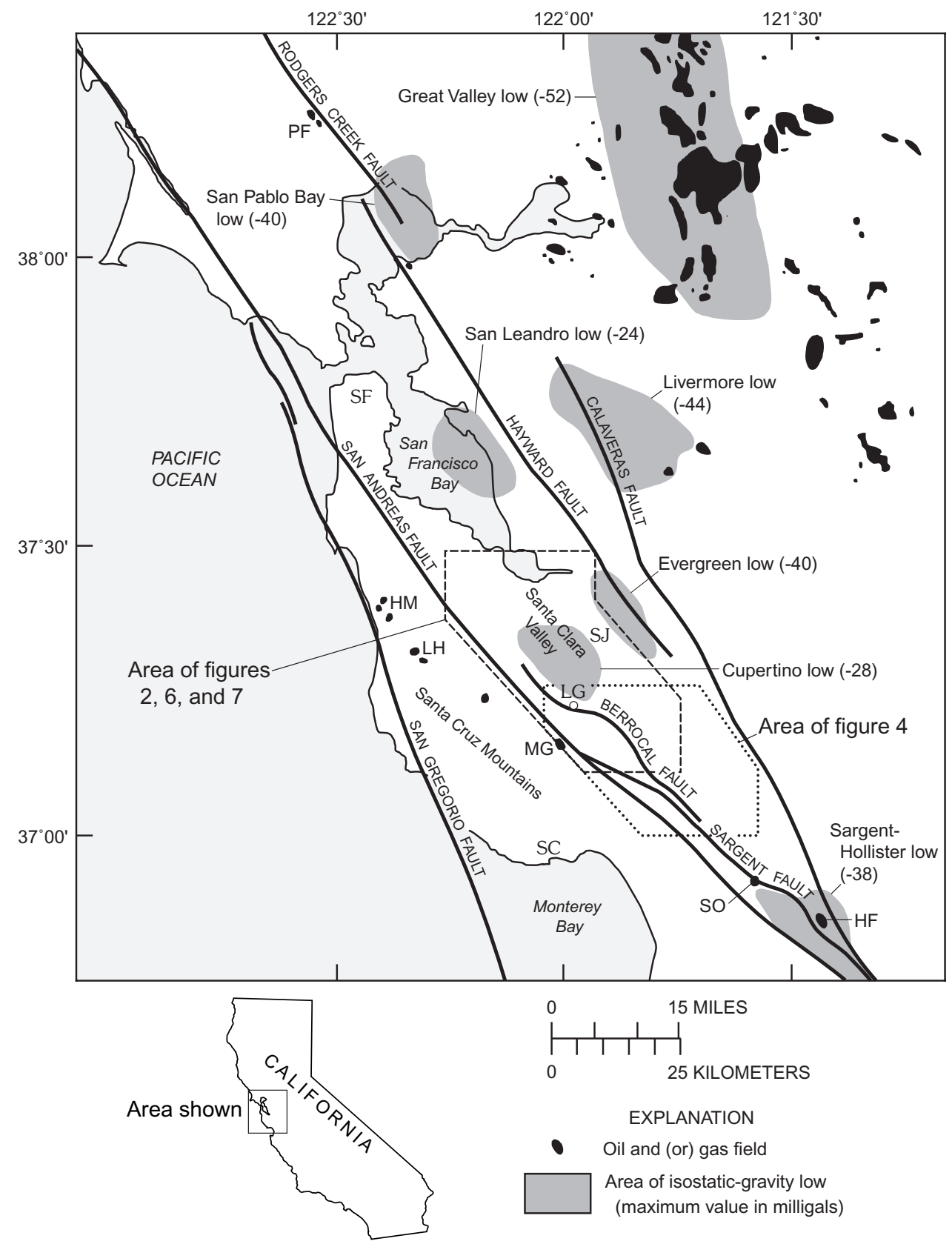

Figure 1.-San Francisco Bay region, showing locations of oil and gas fields (California Division of Oil and Gas, 1982a), isostatic-gravity lows with maximum values in milligals (Roberts and Jachens, 1993), selected major faults, and localities mentioned in text. HF, Hollister oil field; HM, Half Moon Bay oil field; LG, Los Gatos; LH, La Honda oil field; MG, Moody Gulch oil field; PF, Petaluma oil field; SC, Santa Cruz; SF, San Francisco; SJ, San Jose; SO, Sargent oil field. 


\section{Regional Geologic Setting}

The Santa Clara Valley is a broad, mostly flat alluvial plain that extends southward from San Francisco Bay (figs. 1, 2). Major right-lateral strike-slip faults occur on either side of the valley, including the San Andreas Fault on the west and the Hayward and Calaveras Faults on the east (fig. 1). Significant amounts of right-lateral movement, measurable in tens to hundreds of kilometers, have occurred along these faults. Detailed studies of offset deep-sea fans, volcanic fields, and other paleogeographic features show that about 300 to 330 $\mathrm{km}$ of right-lateral displacement has occurred along the San Andreas Fault since about 23 Ma (Hill and Dibblee, 1953; Addicott, 1968; Clarke and Nilsen, 1973; Matthews, 1976; Stanley, 1987b; Graham and others, 1989). Along the segment of the San Andreas Fault immediately west of the Santa Clara
Valley, right-lateral displacement of about 28 to $30 \mathrm{~km}$ has occurred since about 5-3 Ma (Dibblee, 1966a, b; Cummings, 1968; McLaughlin and others, 1996a). Right-lateral offset along the Hayward, Calaveras, and related faults of about 160 to $170 \mathrm{~km}$ has occurred since about $12 \mathrm{Ma}$, possibly since 8 Ma (McLaughlin and others, 1996a). Additionally, an important zone of reverse and dextral(?) faults, collectively termed the "range-front fault system" (Langenheim and others, 1997; McLaughlin and others, 1999), includes the Monte Vista, Berrocal, Shannon, and Sargent Faults (figs. 1, 2) and forms the southwest boundary of the Santa Clara Valley. This range-front fault system, which has played a major role in the geologic evolution of the valley and adjacent Santa Cruz Mountains, is discussed in more detail below.

The San Andreas and Hayward Faults have caused damaging local earthquakes in the past and are likely to do

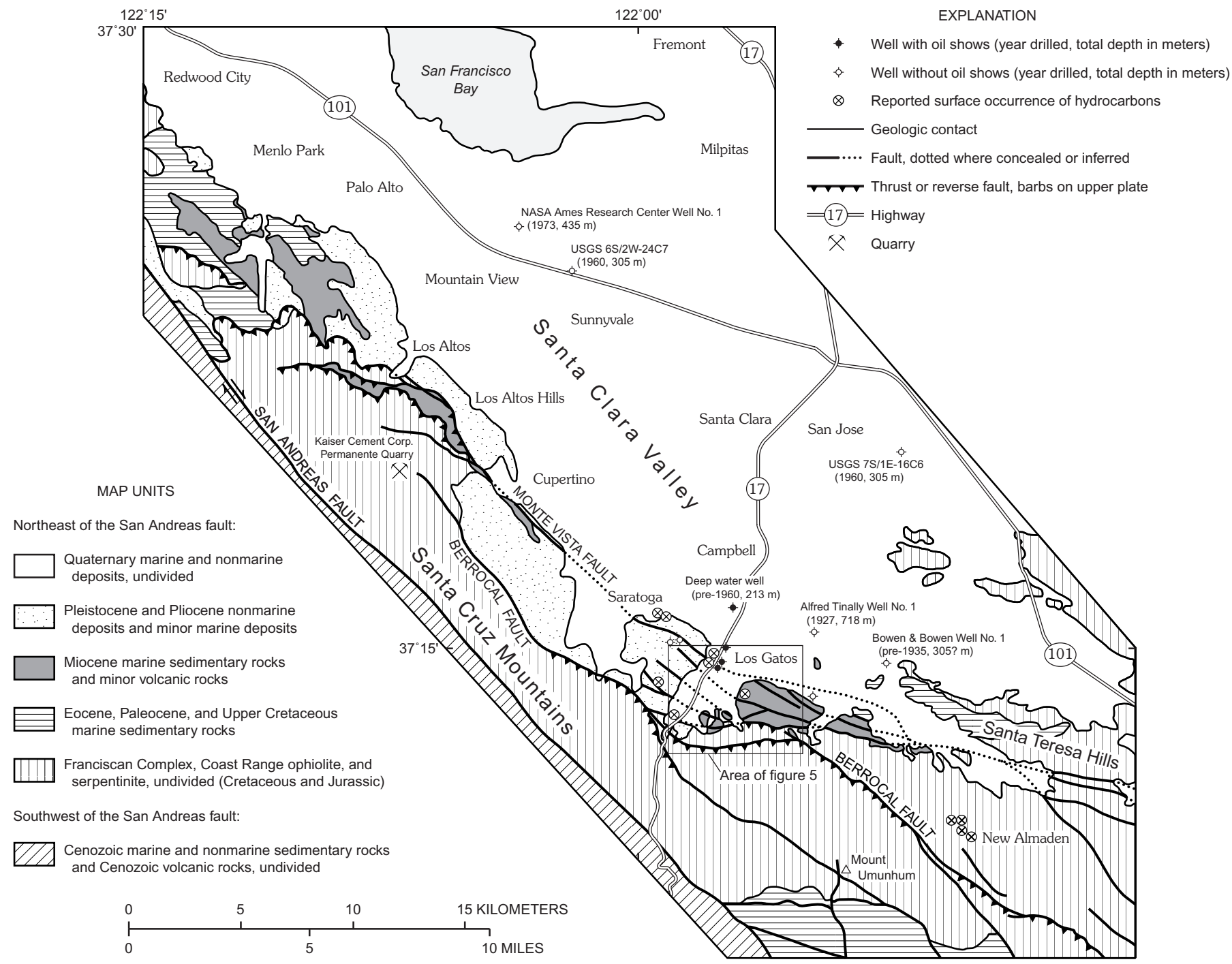

Figure 2.-Generalized geologic map of the southwestern Santa Clara Valley and vicinity, Calif. (fig. 1), showing locations of natural surface occurrences of hydrocarbons and selected wells. Compiled and modified from Wagner and others (1990), Brabb (1993), and McLaughlin and others (2001). 


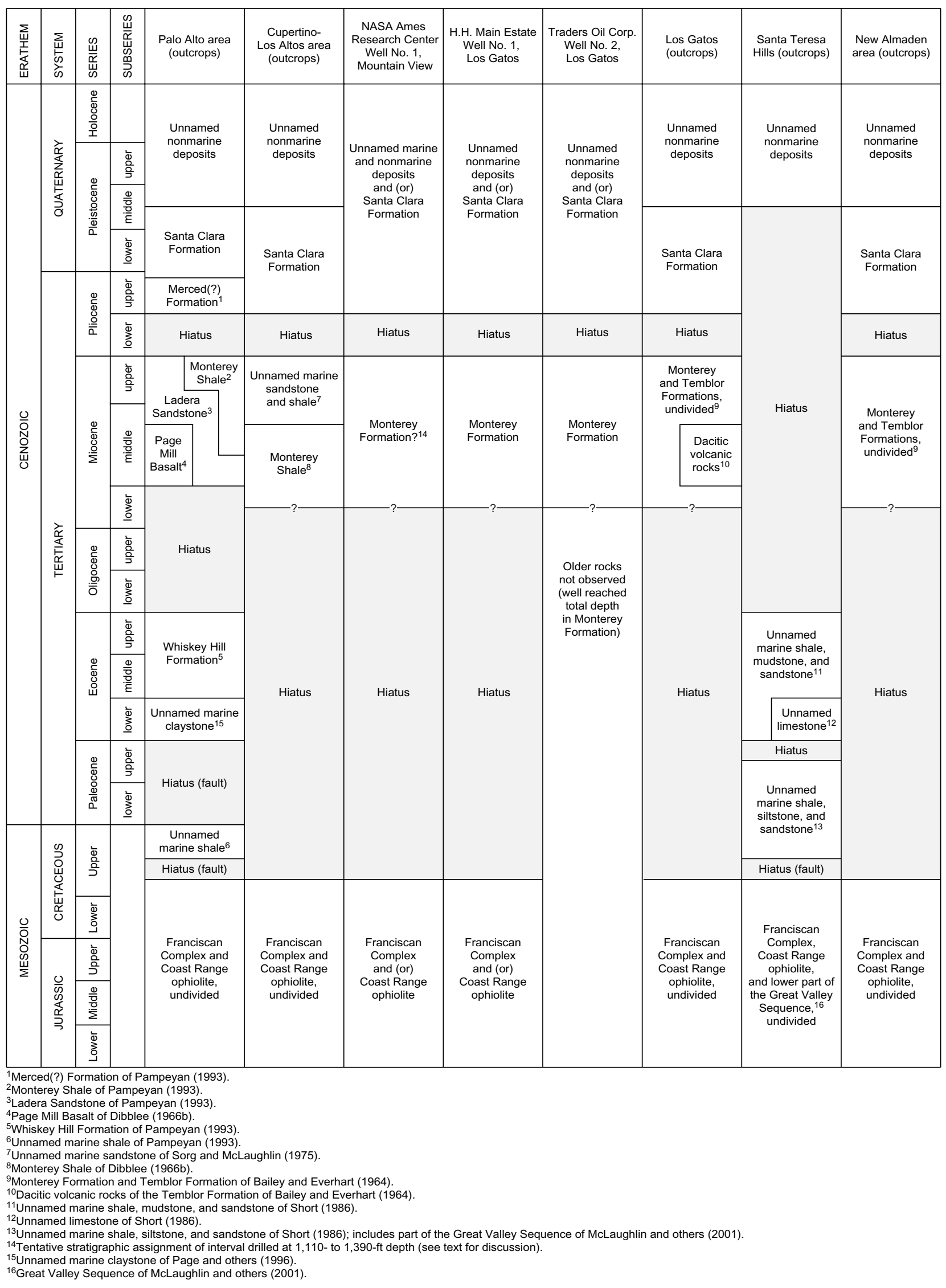

Figure 3.-Stratigraphic chart correlating Mesozoic and Cenozoic rock units in the southwestern Santa Clara Valley and vicinity, Calif. (fig. 1). 
so again (Working Group on California Earthquake Probabilities, 1990). Large, destructive earthquakes occurred along the San Andreas Fault in 1838 and 1906 and along the Hayward Fault in 1836 and, possibly, 1868 (McNutt and Toppozada, 1990, p. 13). During the 1989 Loma Prieta, Calif., earthquake, significant damage occurred in parts of the southwestern Santa Clara Valley, most notably in the Los Gatos area and on the Stanford University campus in Palo Alto (Plafker and Galloway, 1989, p. 16-17; Montgomery, 1990; McNutt, 1990). Some of the 1989 earthquake damage in the Los Gatos area may have been caused by slip at depth along the Monte Vista, Shannon, and Sargent Faults (Haugerud and Ellen, 1990; Bürgmann and others, 1994; Schmidt and others, 1996; Langenheim and others, 1997). Additional faults, some of which may be capable of generating earthquakes, may be hidden beneath the alluvial floor of the Santa Clara Valley (Hitchcock and others, 1994; Langenheim and others, 1997; McLaughlin and others, 1999), but the locations, geometries, and slip histories of these faults are uncertain.

In the Santa Cruz Mountains northeast of the San Andreas Fault, Jurassic and Cretaceous rocks of the Franciscan Complex are overlain by fragments of the Jurassic Coast Range ophiolite and by stratified rocks of Jurassic to Holocene age (figs. 2, 3). Similar rocks are believed to be present in the subsurface beneath the southwestern Santa Clara Valley, as discussed in greater detail below. On the opposite, southwest side of the San Andreas Fault, Cretaceous and older plutonic and metamorphic rocks of the Salinia terrane are overlain by Tertiary sedimentary and volcanic strata with a composite thickness of nearly $15 \mathrm{~km}$ (Cummings and others, 1962; Stanley, 1990). Several small oil fields in the Santa Cruz Mountains southwest of the San Andreas Fault (fig. 1) have produced a total of about 1.7 million barrels of oil and 300 million $\mathrm{ft}^{3}$ of gas, mostly from reservoirs in Eocene turbidite sandstone and Miocene limestone (Stanley, 1990, 1995a, d; California Division of Oil, Gas, and Geothermal Resources, 2000).

\section{Stratigraphy}

\section{Franciscan Complex, Coast Range Ophiolite, Lower Part of the Great Valley Sequence, and Serpentinite}

The oldest rock units in the vicinity of the southwestern Santa Clara Valley include the Jurassic and Cretaceous Franciscan Complex, the Jurassic Coast Range ophiolite, and the lower part of the Great Valley Sequence (figs. 2, 3). The Franciscan Complex in this area consists mainly of rocks assigned to the Permanente, Marin Headlands, and Central terranes (Blake and others, 1984; McLaughlin and others, 2001) of the Central belt of the Franciscan Complex (Irwin, 1960; McLaughlin and others, 1991b). The Permanente terrane consists largely of Cretaceous basaltic volcanic rocks and Cretaceous limestone, with lesser amounts of radiolarian chert, siliceous tuff, melange, sandstone, and argillite (Bailey and Everhart, 1964; Dibblee, 1966b; Sorg and McLaughlin, 1975; Blake and others, 1984; McLaughlin and others, 1991a, b, 2001; Brabb, 1993). The Marin Headlands terrane in this area consists mainly of Cretaceous graywacke sandstone, Jurassic to Cretaceous radiolarian chert, and Lower Jurassic basaltic volcanic rocks (McLaughlin and others, 2001). The Central terrane is a tectonic melange composed mainly of penetratively sheared metasandstone and argillite, with blocks of greenstone, chert, and glaucophane-bearing metamorphic rocks (Short, 1986; McLaughlin and others, 2001). The melange occurs as large, areally extensive bodies that enclose other terranes of the Franciscan Complex, as well as smaller bodies that are interleaved with fragments of other Franciscan terranes (McLaughlin and others, 2001).

In the subsurface, rocks of the Franciscan Complex are inferred to occur at depth beneath the entire southwestern Santa Clara Valley (Jachens and others, 1995; Stanley and others, 1996, 1998). Rocks that may represent the Franciscan Complex were penetrated by H.H. Main Estate Well No. 1 in Los Gatos and by NASA Ames Research Center Well No. 1 in Mountain View (fig. 2; table 1), as described below.

Fragments of the Coast Range ophiolite are represented by a large slab, about 1,600 to $1,700 \mathrm{~m}$ thick, of mafic to ultramafic igneous rocks in the Loma Prieta and Mount Umunhum areas (figs. 2, 4), by serpentinite exposed in and near the Santa Teresa Hills (fig. 2), and by discontinuous, fault-bounded bodies of ultramafic to mafic rocks along the Berrocal Fault zone (McLaughlin and others, 1991a, b, 2001). Evidence from regional magnetic studies and surface geologic mapping suggests that fragments of the Coast Range ophiolite occur in the subsurface beneath the southwestern Santa Clara Valley (Brabb and Hanna, 1981; Jachens and Roberts, 1993; Langenheim and others, 1997). Greenstone at the bottom of NASA Ames Research Center Well No. 1 and serpentinite in Main Estate Well No. 1 may represent either the Franciscan Complex or fragments of the Coast Range ophiolite.

Locally, in the southeastern Santa Cruz Mountains and the Santa Teresa Hills, the Franciscan Complex and Coast Range ophiolite are structurally overlain, along low-angle faults, by marine strata of Late Jurassic (Tithonian) to Early Cretaceous (Valanginian) age. These strata, which were assigned by McLaughlin and others (2001) to the lower part of the Great Valley Sequence, consist mainly of dark-green to black shale and minor lithic sandstone. Upper Jurassic to Lower Cretaceous strata may be present in the subsurface beneath the Santa Clara Valley but were not identified in the wells studied for this report.

Masses of partially to completely serpentinized peridotite occur as fault-bounded bodies within the Franciscan Complex (Bailey and Everhart, 1964; Dibblee, 1966b; Sorg and McLaughlin, 1975; McLaughlin and others, 1991a; Brabb, 1993). In places, the serpentinite has been hydrothermally altered to silica-carbonate rock, which is the principal host for mercury ore in the now-inactive New Almaden mining district (Bailey and Everhart, 1964). Emplacement of the mercury ores is thought to have begun during the Miocene (McLaughlin and others, 2001) and may have continued into 
the Pliocene (Bailey and Everhart, 1964). The mercury mineralization apparently occurred at depths ranging from the surface to about $800 \mathrm{~m}$ and at temperatures of about $50-150^{\circ} \mathrm{C}$ (Bailey and Everhart, 1964). At several localities in the New Almaden area, the silica-carbonate rocks contain sparse hydrocarbons that occur as droplets and films of tar and oil (Bailey and Everhart, 1964; Peabody, 1993). We collected and analyzed hydrocarbons from one such occurrence near New Almaden, as discussed below in the section entitled "Organic Geochemistry of Oils and Source Rocks."

\section{Upper Cretaceous to Eocene Strata}

Northeast of the Berrocal Fault zone, in the Santa Teresa Hills and nearby areas (figs. 2, 3), the Franciscan Complex and Coast Range ophiolite are structurally overlain, along low-angle faults (McLaughlin and others, 2001), by unnamed marine sedimentary rocks of Late Cretaceous to Eocene age (Bailey and Everhart, 1964; Short, 1986). These strata consist mainly of shale, mudstone, siltstone, and sandstone that apparently represent deep-sea-fan and abyssal-plain deposits. Locally, the strata include lenses of fossiliferous lower Eocene limestone (Bailey and Everhart, 1964; Blondeau and Brabb, 1983; Short, 1986). The thickness of the Upper Cretaceous to Eocene sequence in the Santa Teresa Hills is uncertain, owing to poor exposure, complex structure, and at least one internal unconformity, but the sequence appears to be about 1,000 m thick (Short, 1986, p. 14).
Upper Cretaceous to Eocene rocks also occur in the Palo Alto area (figs. 2, 3; see Dibblee, 1966b; Page and Tabor, 1967; Pampeyan, 1993), but stratigraphic correlations between the Palo Alto area and the Santa Teresa Hills are uncertain. Unnamed Upper Cretaceous marine shale is known from a single outcrop near Palo Alto, where the shale has a maximum stratigraphic thickness of about $30 \mathrm{~m}$ and is in fault contact with Eocene strata and the Pliocene and Pleistocene Santa Clara Formation (Pampeyan, 1993). Unnamed lower Eocene marine claystone occurs in scattered exposures, including the diapiric core of an anticline on the Stanford University campus (Page and others, 1996). The Eocene Whiskey Hill Formation (Pampeyan, 1993) of the Palo Alto area (fig. 3) rests unconformably on the Franciscan Complex, is about 900 to 1,200 $\mathrm{m}$ thick, contains foraminifers of middle and late Eocene age (Page and others, 1996), and consists mainly of sandstone, siltstone, and claystone that were deposited by turbidity currents and submarine slumps in bathyal marine environments (Beaulieu, 1970; Page and others, 1996).

Although Late Cretaceous to Eocene rocks may occur in the subsurface beneath the southwestern Santa Clara Valley, available data indicate that correlative rocks were not penetrated by the exploratory oil wells studied for this report.

\section{Miocene Strata}

In the Los Gatos and New Almaden areas (figs. 2, 3), Miocene strata rest unconformably on the Franciscan Com-

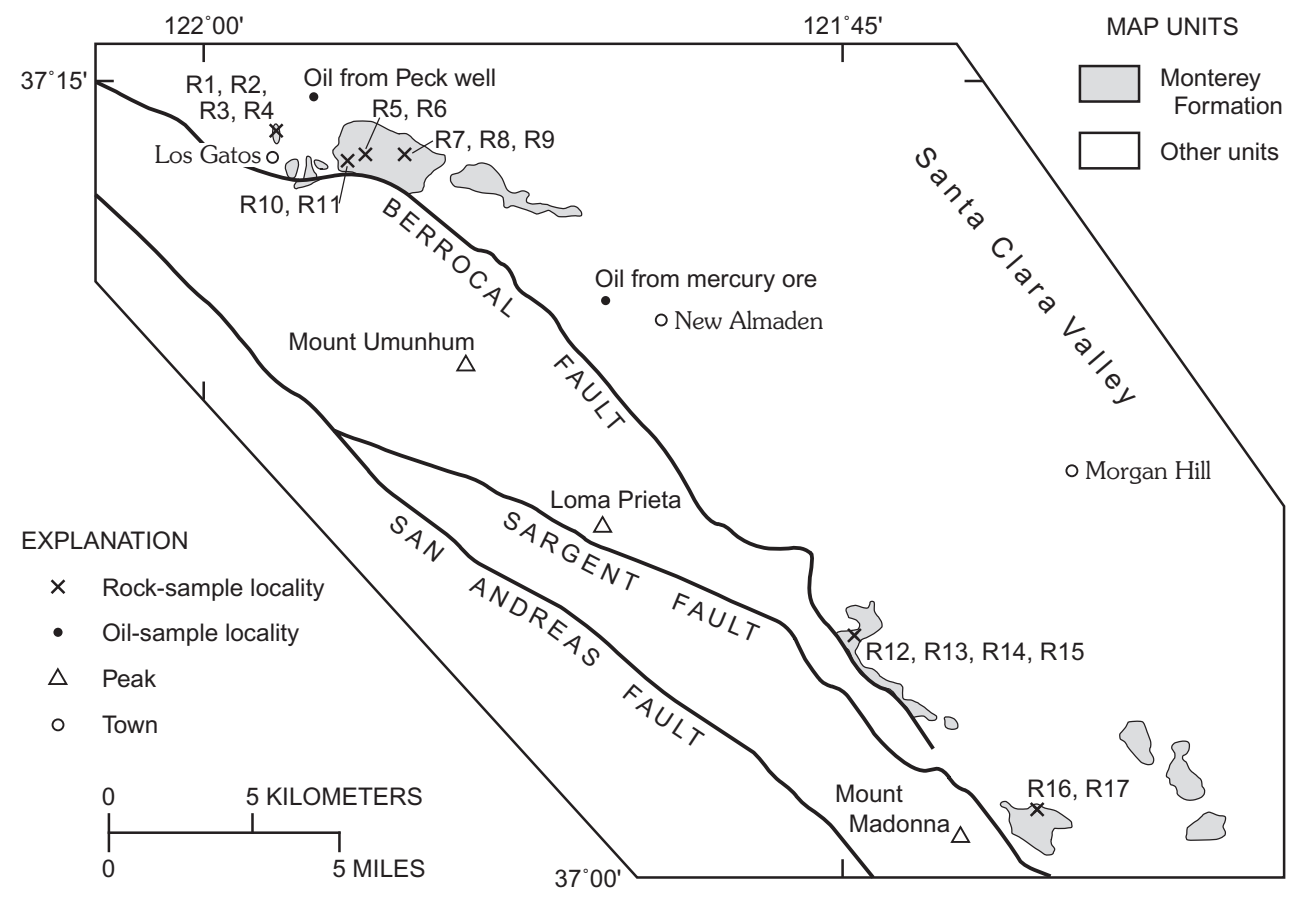

Figure 4.- Part of southwestern Santa Clara Valley and vicinity, Calif. (fig. 1), showing localities from which samples of oil and Miocene marine shale and mudstone were collected for biostratigraphic and organic-geochemical analysis. See appendix for additional locality information. 
Table 1.-Exploratory oil wells in the southwestern Santa Clara Valley, Calif., listed in approximate order of drilling.

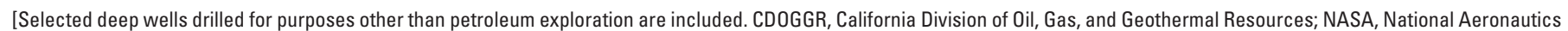
and Space Administration; USGS, U.S. Geological Survey. Do., ditto]

\begin{tabular}{|c|c|c|c|c|c|}
\hline $\begin{array}{l}\text { Section, } \\
\text { township, } \\
\text { range }\end{array}$ & $\begin{array}{l}\text { 7.5-minute } \\
\text { quadrangle }\end{array}$ & Well name (if known) & $\begin{array}{l}\text { Year(s) } \\
\text { drilled }\end{array}$ & $\begin{array}{c}\text { Total } \\
\text { depth } \\
\text { (ft) }\end{array}$ & Remarks \\
\hline
\end{tabular}

Sec. 10 or 15 ,

(projected)

Sec. 10 or 15 ,

T. 8 S., R. 1 W.

(projected)

Sec. 10 or 15 ,

T. 8 S., R. 1 W. (projected)
T. 8 S., R. 1 W.

\section{Los Gatos}

Main Estate Well No. 1

1891

754

do

- Main Estate Well No. 2

1894

200

do--------- Main Estate Well No. 3

1896-97

$574+$

Uncertain

Orchard Crude Oil Co. Well No. 4 ---

1902

$\geq 700$

Uncertain;

probably

sec. 10 or 15 ,

T. 8 S., R. 1 W.

(projected)

Uncertain; possibly

sec. 10 or 15 ,

T. 8 S., R. 1 W

(projected)

Uncertain; possibly

sec. 10 or 15 ,

T. 8 S., R. 1 W.

Sec. 5 ,

T. 8 S., R. 1 W. (projected)

Sec. 9,

T. 8 S., R. 1 W. (projected)

Sec. 8 ,

T. 8 S., R. 1 W. (projected)

Sec. 13, T. 8 S., R. 1 W.
Los Gatos Well on ranch of R.C. McPherson---- pre-1914

Los Gatos? Suburban Oil Co. Well No. 1

1911

do-Unnamed well "near the reservoir of
the San Jose Water Company,
on the San Jose road two miles
northeast of Los Gatos...on the northeast of Los Gatos...on the south side of San Jose road."

San Jose West Unnamed well on the south side of pre-1918 Pollard Road.

do--------- Well of S.G. Kearney

pre-1918

do--------- Well of Marion

pre-1918

Los Gatos

"Old oil well"

pre-1918
85

$\geq 2,750$ (1914, p. 470), who stated that the well "pierced three oil strata," but gave no additional information. No well history or logs.

$30+$

Known only from Forstner's map (fig. 8) with the notation "tar sand at $30 \mathrm{ft}$ as claimed by Piper." No well history or logs.

Uncertain Known only from Forstner's map (fig. 8). No well history or logs.

Uncertain Known only from Forstner's map (fig. 8). No well history or logs.

Uncertain Known only from Forstner's map (fig. 8). No well history or logs. This may or may not be the same hole as El Capitan Well No. 1. 
Table 1.-Exploratory oil wells in the southwestern Santa Clara Valley, Calif., listed in approximate order of drilling—Continued.

\begin{tabular}{|c|c|c|c|c|c|}
\hline $\begin{array}{l}\text { Section, } \\
\text { township, } \\
\text { range }\end{array}$ & $\begin{array}{l}\text { 7.5-minute } \\
\text { quadrangle }\end{array}$ & Well name (if known) & $\begin{array}{l}\text { Year(s) } \\
\text { drilled }\end{array}$ & $\begin{array}{c}\text { Total } \\
\text { depth } \\
\text { (ft) }\end{array}$ & Remarks \\
\hline
\end{tabular}

Sec. 10, Los Gatos $\quad$ Piper oil well --------------------- pre-1918 1,650

T. 8 S., R. 1 W.

Uncertain $\quad$ Uncertain $\quad$ El Capitan Well No. 1 ----------------- pre-1918

Do

do-

pre-1918

$\geq 1,017$

Do

do-------- T.A.P. Oil Co. Well No. 1

2,035

Uncertain; probably

sec. 14 ,

T. 8 S., R. 1 W.

Sec. 10 , Los Gatos

Traders Oil Corp. Well No. 2

1919-20

2,675 (Rasmussen).

T. 8 S., R. 1 W.

Sec. 7,

T. 8 S., R. 1 E.

Uncertain; probably

sec. 10 or 15 ,

T. 8 S., R. 1 W.,

but possibly

sec. 9 ,

T. 8 S., R. 1 W. (projected)

Sec. 16(?),

T. 8 S., R. 1 E.

Sec. 10,

T. 8 S., R. 1 W.

(projected)

Los Gatos or

Carl Crossen Well No. 1

2,006

$\geq 800$
San Jose West Alfred Tinally Well No.

San Jose West

Unpublished, handwritten driller's log available from CDOGGR, but no information on location. Shows of oil and gas. This well may or may not be the same as the "old oil well" on Forstner's map (fig. 8).

Unpublished, handwritten driller's log available from CDOGGR, but no information on location. Shows of oil and gas.

Unpublished, handwritten driller's log available from CDOGGR, which gives the location as "Los Gatos, Calif." with no additional details. Shows of oil and gas. This well may or may not be the same as the Piper oil well shown on Forstner's map (fig. 8).

Unpublished driller's log available from CDOGGR. Location uncertain (see text for discussion). Hole was begun in 1915 by T.A. Piper, then taken over and deepened in 1918 by Traders Oil Corp. Shows of oil and gas. Completed as a water well.

Unpublished driller's log available from CDOGGR. Location near present-day intersection of Lark Avenue and California Highway 17. Shows of oil and gas. Completed as a water well.

2,356 No well history or logs.

615 Unpublished driller's log available from CDOGGR. Location uncertain (see text for discussion). Shows of oil. Completed as a water well.

pre-1935 $\pm 1,000$

No shows of oil or gas. No well history or logs.

125+ Located in parking lot at 15405 Los Gatos Boulevard, Los Gatos. Pump unit installed in 1947 to obtain oil from 125$\mathrm{ft}$ depth. No well history or logs. 
Table 1.-Exploratory oil wells in the southwestern Santa Clara Valley, Calif., listed in approximate order of drilling—Continued.

\begin{tabular}{|c|c|c|c|c|c|}
\hline $\begin{array}{l}\text { Section, } \\
\text { township, } \\
\text { range }\end{array}$ & $\begin{array}{l}\text { 7.5-minute } \\
\text { quadrangle }\end{array}$ & Well name (if known) & $\begin{array}{l}\text { Year(s) } \\
\text { drilled }\end{array}$ & $\begin{array}{l}\text { Total } \\
\text { depth } \\
\text { (ft) }\end{array}$ & Remarks \\
\hline $\begin{array}{l}\text { Sec. 24, } \\
\text { T. } 6 \text { S., R. 2 W. } \\
\text { (projected) }\end{array}$ & Mountain View & v USGS Corehole 6S/2W-24C------- & 1960 & 1,004 & $\begin{array}{l}\text { Located in Sunnyvale near intersection of } \\
\text { U.S. Highway } 101 \text { and California State } \\
\text { Highway } 237 \text {. Drilled for hydrologic } \\
\text { and engineering information. No } \\
\text { reported shows of oil or gas. Electrical } \\
\text { and lithologic logs reported by Johnson } \\
\text { and others (1968). }\end{array}$ \\
\hline $\begin{array}{l}\text { Sec. 16, } \\
\text { T. } 7 \text { S., R. 1 E. } \\
\text { (projected) }\end{array}$ & San Jose East & USGS Corehole 7S/1E-16C6 --------- & 1960 & 1,002 & $\begin{array}{l}\text { Located in San Jose along California } \\
\text { Interstate Highway } 280 \text { near Coyote } \\
\text { Creek. Drilled for hydrologic and } \\
\text { engineering information. No reported } \\
\text { shows of oil or gas. Electrical and } \\
\text { lithologic logs reported by Johnson and } \\
\text { others (1968). }\end{array}$ \\
\hline
\end{tabular}

plex (Bailey and Everhart, 1964; McLaughlin and others, 1991a, 1999) and consist mainly of conglomerate, sandstone, siliceous shale, and dacitic volcanic rocks. The stratigraphic thickness of these Miocene rocks is uncertain because of complex structure and because the top of the Miocene is everywhere eroded. Published estimates of the total thickness of Miocene strata represented by outcrops in the Los Gatos and New Almaden areas range from about $640 \mathrm{~m}$ (McLaughlin and others, 1991a, p. 12) to about 1,160 m (Bailey and Everhart, 1964, p. 71). However, in the subsurface beneath parts of the southwestern Santa Clara Valley, the Miocene strata may be as thick as 3,000 m, as suggested below.

Bailey and Everhart (1964) divided the Miocene rocks of the Los Gatos and New Almaden areas into two units: (1) an older, conglomerate- and sandstone-rich unit, the Temblor Formation; and (2) a younger, shale-rich unit, the Monterey Formation. Available biostratigraphic evidence and isotopic ages from interstratified volcanic rocks, discussed below, suggest considerable overlap in the ages of the Temblor and Monterey Formations as mapped by Bailey and Everhart (1964). Recent reconnaissance field studies by R.G. Stanley and R.J. McLaughlin (unpub. data, 1994-96) found new roadcuts and other outcrops revealing that formerly covered intervals mapped as Temblor Formation by Bailey and Everhart (1964) consist entirely of fine-grained rocks typical of the Monterey Formation. In some places, we discovered sedimentary structures indicating that the Monterey Formation has been locally overturned by post-Miocene folding and faulting and that the Monterey is stratigraphically overlain by sandy and conglomeratic strata previously mapped as Temblor Formation by Bailey and Everhart (1964). Locally, sand- stone beds of the Temblor Formation contain shallow-marine mollusks of Miocene age, as well as microfossils of Eocene age that likely were derived from older strata and redeposited (Blondeau and Brabb, 1983; McLaughlin and others, 1999). These revelations indicate that the stratigraphy and structure of Miocene rocks in the Los Gatos area are more complex than previously thought and that further geologic field mapping and biostratigraphic studies are needed.

In the Los Gatos and New Almaden areas, the Temblor Formation as mapped by Bailey and Everhart (1964) consists mainly of conglomerate and sandstone, with lesser amounts of siliceous shale. The conglomerate includes clasts derived from the Franciscan Complex and from other Jurassic to lower Tertiary strata in the Santa Cruz Mountains and Santa Teresa Hills (McLaughlin and others, 1991a). The sandstone is generally medium to fine grained and quartzofeldspathic to lithic in composition. In some places near New Almaden, the sandstone contains abundant fossils and fragments of clams, oysters, bryozoans, and barnacles that suggest deposition in shallow-marine environments (McLaughlin and others, 1991a). However, in reconnaissance examinations of several outcrops mapped as Temblor Formation by Bailey and Everhart (1964) in eastern Los Gatos (locs. R5, R6, R10, R11, fig. 5), we observed interbedded sequences of sandstone and shale in which the sandstone exhibited normal grading, partial Bouma sequences, and other sedimentary structures indicative of deposition by turbidity currents in relatively quiet, deep water. Benthicforaminiferal assemblages in these strata indicate deposition at upper-bathyal depths (approx 150-500 m), with some material transported and redeposited from shallower depths 
(table 2). In outcrops mapped as Temblor Formation by Bailey and Everhart (1964) along Kennedy Road, about 4 to $5 \mathrm{~km}$ east of the Los Gatos Post Office (fig. 5), we collected specimens of Pacipecten cf. P. andersoni (Arnold), representative of the early and middle Miocene "Temblor" provincial molluscan stage (fossil identification and age by J.G. Vedder, oral commun., 1995).

About 7 to $9 \mathrm{~km}$ east of the Los Gatos Post Office (fig. 5), a laterally persistent horizon of dacitic tuff breccia, as much as about $12 \mathrm{~m}$ thick, occurs within the upper part of

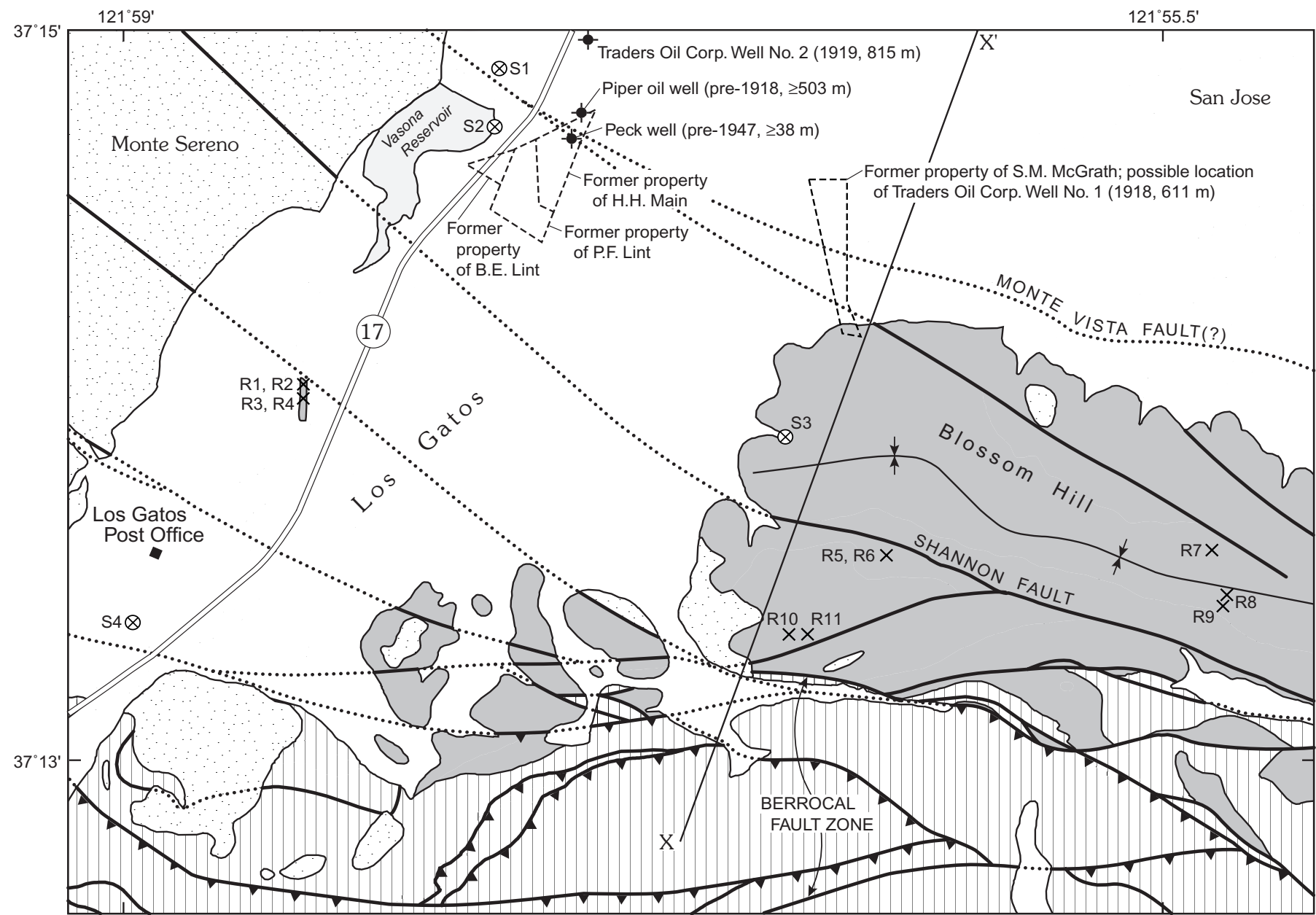

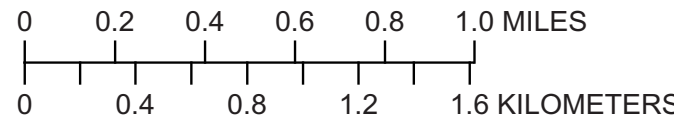

MAP UNITS

Quaternary marine and nonmarine deposits, undivided

Santa Clara Formation (Pleistocene and Pliocene nonmarine deposits)

Miocene marine sedimentary rocks and minor volcanic rocks (including the Temblor and Monterey Formations of Bailey and Everhart, 1964)

Franciscan Complex, Coast Range ophiolite, and serpentinite, undivided (Cretaceous and Jurassic)

\section{EXPLANATION}

$-\quad$ Well with oil shows (year drilled, total depth in meters)

S4 $\otimes \quad$ Reported surface occurrence of hydrocarbons

R4 X Rock-sample locality (see appendix)

Geologic contact

Fault, dotted where concealed or inferred

Thrust or reverse fault, barbs on upper plate

$\downarrow$ Axis of syncline

$\mathrm{X}-\mathrm{X}^{\prime} \quad$ Line of cross section (fig. 14)

Boundary of property discussed in text

$=17=$ Highway

Figure 5.-Generalized geologic map of the Los Gatos area, southwestern Santa Clara Valley, Calif. (fig. 1), showing locations of selected wells, localities mentioned in text, and line of cross section in figure 14. Modified from Bailey and Everhart (1964). 
the Temblor Formation as mapped by Bailey and Everhart (1964). Plagioclase from this tuff breccia yielded a K-Ar

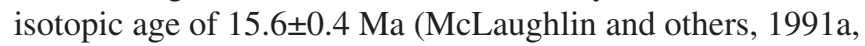
p. 13; Nakata and others, 1993, p. 28), or middle Miocene (Berggren and others, 1995, p. 142-143). Other, nearby occurrences of presumably correlative volcanic rocks include (1) a conspicuous mass of dacite, more than $60 \mathrm{~m}$ thick, on Lone Hill, about $7 \mathrm{~km}$ northeast of the Los Gatos Post Office; and (2) smaller bodies of dacite that appear to intrude lower Eocene strata in a small area west of the Santa Teresa Hills and about $8 \mathrm{~km}$ east of the Los Gatos Post Office (Bailey and Everhart, 1964; McLaughlin and others, 1991a).

In the Los Gatos area, the Monterey Formation as mapped by Bailey and Everhart (1964) consists mainly of well-bedded siliceous mudstone, shale, and porcelanite, with minor interbeds of sandstone, conglomerate, and bentonite. Orange-weathering dolomitic beds and concretions are present at some localities. The mudstone, shale, and porcelanite are white weathering in outcrop but brown on fresh surfaces and contain abundant fossil foraminifers and fish fragments. Rock samples from the Monterey Formation in the Los Gatos area (locs. R1-R11, fig. 5; table 2) yielded benthic-foraminiferal assemblages representative of the late Relizian to Luisian stages of Kleinpell (1938, 1980), indicating that the Monterey in this area is partly or entirely middle Miocene in age.

In the Cupertino-Los Altos area (fig. 3), Miocene rocks include the Monterey Shale of Dibblee (1966b), the Monterey Shale of Sorg and McLaughlin (1975), and an overlying, unnamed unit consisting of marine sandstone and shale of middle and late Miocene age (Sorg and McLaughlin, 1975). The thickness of the Monterey Shale of Dibblee (1966b) is uncertain, owing to poor outcrop and complex structure, but the unit may be more than $600 \mathrm{~m}$ thick (Dibblee, 1966b). The Monterey Shale of Dibblee (1966b), which consists mainly of siliceous shale and siltstone south of Los Altos and consists mainly of clay shale and siltstone near Los Altos (Dibblee, 1966b), may grade laterally northwestward into fine-grained sandstone (Ladera Sandstone of Pampeyan, 1993) in the Palo Alto area. The age of the Monterey Shale of Dibblee (1966b) in the Cupertino-Los Altos area is poorly known, but foraminifers of early to middle Miocene age (Relizian stage of Kleinpell, 1938, 1980) were found in "siliceous shale exposed about half a mile southwest of Los Altos Country Club" (Cummings and others, 1962, p. 195; Dibblee, 1966b). At a construction-site excavation near Foothill College in the Los Altos Hills, the Monterey Shale of Dibblee (1966b) yielded nannofossils of the early and middle Miocene CN3 and (or) middle Miocene CN4 zone, as well as benthic foraminifers indicative of the middle Miocene Luisian stage of Kleinpell $(1938,1980)$ and suggestive of deposition at water depths of about 500 to 1,500 m (David Bukry and K.A. McDougall, in McLaughlin and others, 1991a, p. 12; McLaughlin and others, 1991b, p. 49). In the Cupertino area, the middle Miocene Monterey Shale of Sorg and McLaughlin (1975) is conformably overlain by an unnamed unit consisting of fossiliferous, bioturbated, locally crosslaminated sandstone with interbeds of shale (Sorg and
McLaughlin, 1975). This unnamed sandstone and shale unit contains abundant shallow-marine molluscan fossils of middle and late Miocene age (Sorg and McLaughlin, 1975). The thickness of the unnamed unit is uncertain because its upper contact is everywhere eroded, but cross sections drawn by Sorg and McLaughlin (1975) suggest that the unit is at least $250 \mathrm{~m}$ thick.

In the Palo Alto area (figs. 2, 3), Miocene rocks include the middle Miocene Page Mill Basalt (Dibblee, 1966b), the middle and upper Miocene Ladera Sandstone (Pampeyan, 1993), and the middle and upper Miocene Monterey Shale of Pampeyan (1993). The Page Mill Basalt rests on the Eocene Whiskey Hill Formation, is overlain by and laterally equivalent to the Ladera Sandstone, and consists mainly of olivine basalt flows and breccia. The Page Mill Basalt is about 180 $\mathrm{m}$ thick in quarries along Old Page Mill Road near Junipero Serra Boulevard in Palo Alto and thins to 0 away from there, suggesting that the basalt was erupted from a vent in that area (Pampeyan, 1993). Mark Mason (oral commun., 1989) obtained a K-Ar age on the Page Mill Basalt of 14.0 \pm 0.5 Ma, whereas Turner (1970, p. 106) reported a K-Ar age of 14.8 $\pm 2.4 \mathrm{Ma}$ (corrected for changes in decay constants by using the method of Dalrymple, 1979).

The Ladera Sandstone is about 300 to $460 \mathrm{~m}$ thick and consists mainly of bioturbated, crosslaminated, and fossiliferous feldspathic sandstone that was deposited in shallow-marine environments. The Ladera Sandstone rests unconformably on the Eocene Whiskey Hill Formation where the Page Mill Basalt is absent; however, in some places, the contact between the Ladera Sandstone and the Whiskey Hill Formation is sheared and may be a decollement (Page and Tabor, 1967). The Ladera Sandstone grades upward and interfingers southward into siliceous siltstone and shale of the Monterey Shale of Pampeyan (1993). In the Palo Alto area, the Monterey Shale of Pampeyan (1993) is about 370 to 600 $\mathrm{m}$ thick and contains benthic foraminifers of Delmontian age, diatoms that indicate a late Luisian or early Mohnian age, and fish scales and molds of foraminifers of early or middle Miocene age (Pampeyan, 1993).

Miocene strata have been identified in several wells in the Los Gatos area, as described below. Miocene rocks are thought to be the principal hydrocarbon-source and hydrocarbon-reservoir rocks beneath the southwestern Santa Clara Valley.

\section{Pliocene Marine Strata}

In the southwestern Santa Clara Valley east of the San Andreas and Pilarcitos Faults, marine strata of Pliocene age are known only from outcrops near Palo Alto, where poor exposures of friable, fossiliferous, fine-grained sandstone were mapped by Dibblee (1966b) and Pampeyan (1993) as the Merced(?) Formation (fig. 3). In this area, the Merced(?) Formation rests unconformably on the Monterey Shale of Pampeyan (1993), is about $30 \mathrm{~m}$ thick, and contains abundant molluscan fossils that indicate a late Pliocene age and shallowmarine depositional environment (Addicott, 1969; Pampeyan, 
Table 2.-Age-diagnostic taxa, ages, and paleobathymetry of benthic foraminifers from outcrop samples of Miocene marine sedimentary strata in the southwestern Santa Clara Valley and vicinity, Calif.

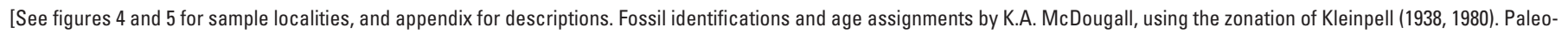
bathymetry based on depth-related biofacies of Ingle (1980). Do., ditto]

\begin{tabular}{|c|c|c|c|c|c|}
\hline Sample & Formation & $\begin{array}{l}\text { Age-diagnostic and } \\
\text { associated taxa }\end{array}$ & Age & Paleobathymetry & Remarks \\
\hline R1 & Monterey & $\begin{array}{l}\text { Anomalina salinasensis Kleinpell, } \\
\text { Dentalina pseudoobliqua Finger } \\
\text { and Lipps, Gyroidina relizana } \\
\text { Kleinpell, Lenticulina miocenica } \\
\text { (Chapman), Pullenia miocenica } \\
\text { Kleinpell, Uvigerinella californica } \\
\text { (Bagg), Valvulineria californica } \\
\text { Cushman, Valvulineria californi- } \\
\text { ca Cushman, V. miocenica Cushman. }\end{array}$ & $\begin{array}{l}\text { Middle Miocene, } \\
\text { early Luisian } \\
\text { Stage. }\end{array}$ & $\begin{array}{l}\text { Upper middle bathyal } \\
(500-1,500 \mathrm{~m}) .\end{array}$ & $\begin{array}{l}\text { Assemblage also includes Denta- } \\
\text { lina quadrulata (Cushman and } \\
\text { Parker), Planulina baggi Klein- } \\
\text { pell, and Plectofrondicularia } \\
\text { californica (Cushman and } \\
\text { Stewart), which suggest an } \\
\text { older Luisian or possibly latest } \\
\text { Relizian age. }\end{array}$ \\
\hline $\mathrm{R} 2$ & Monterey & $\begin{array}{l}\text { Anomalina salinasensis Kleinpell, } \\
\text { Dentalina pseudoobliqua Finger } \\
\text { and Lipps, Gyroidina relizana } \\
\text { Kleinpell, Lenticulina miocenica } \\
\text { (Chapman), Siphogenerina bran- } \\
\text { neri (Bagg), Valvulineria califor- } \\
\text { nica Cushman. }\end{array}$ & $\begin{array}{l}\text { Middle Miocene, } \\
\text { early Luisian } \\
\text { Stage. }\end{array}$ & $\begin{array}{l}\text { Upper middle bathyal } \\
(500-1,500 \mathrm{~m}) .\end{array}$ & --- \\
\hline R5 & $\begin{array}{l}\text { Probable } \\
\text { Monterey }^{1}\end{array}$ & $\begin{array}{l}\text { Dentalina pseudoobliqua Finger and } \\
\text { Lipps, Pullenia miocenica Klein- } \\
\text { pell, Uvigerinella californica } \\
\text { Cushman, Valvulineria californi- } \\
\text { ca Cushman, V. miocenica Cush- } \\
\text { man. }\end{array}$ & $\begin{array}{l}\text { Middle Miocene, } \\
\text { Luisian Stage. }\end{array}$ & $\begin{array}{l}\text { Upper bathyal (150- } \\
500 \text { m), with some } \\
\text { material transported } \\
\text { from outer shelf and } \\
<4 \text { percent of material } \\
\text { representative of } \\
\text { upper-middle-bathyal } \\
\text { depths. }\end{array}$ & $\begin{array}{l}\text { Sample collected from overturned } \\
\text { beds. }\end{array}$ \\
\hline R6 & $\begin{array}{l}\text { Probable } \\
\text { Monterey }^{1}\end{array}$ & $\begin{array}{l}\text { Dentalina pseudoobliqua Finger and } \\
\text { Lipps, Lenticulina miocenica } \\
\text { (Chapman), L. smileyi (Kleinpell), } \\
\text { Marginulina beali (Cushman), } \\
\text { Pullenia miocenica Kleinpell, } \\
\text { Uvigerinella californica Cush- } \\
\text { man, Valvulineria californica } \\
\text { Cushman, V. miocenica Cushman. }\end{array}$ & $\begin{array}{l}\text { Middle Miocene, } \\
\text { Luisian Stage. }\end{array}$ & $\begin{array}{l}\text { Upper bathyal (150- } \\
500 \mathrm{~m}) \text {, with some } \\
\text { material transported } \\
\text { from both inner and } \\
\text { outer shelf, and }<3 \\
\text { percent of material } \\
\text { representative of } \\
\text { upper-middle-bathyal } \\
\text { depths. }\end{array}$ & $\begin{array}{l}\text { Sample collected from overturned } \\
\text { beds. }\end{array}$ \\
\hline $\mathrm{R} 8$ & Monterey & $\begin{array}{l}\text { Dentalina pseudoobliqua Finger and } \\
\text { Lipps, Gyroidina relizana Klein- } \\
\text { pell, Hanzawaia basiloba, Pulle- } \\
\text { nia miocenica Kleinpell, Siphoge- } \\
\text { nerina branneri (Bagg), Uvigeri- } \\
\text { nella californica Cushman, Val- } \\
\text { vulineria californica Cushman. }\end{array}$ & $\begin{array}{l}\text { Middle Miocene, } \\
\text { early Luisian } \\
\text { Stage. }\end{array}$ & $\begin{array}{l}\text { Upper middle bathyal } \\
(500-1,500 \mathrm{~m}), \text { with } \\
\text { considerable transport } \\
\text { from upper-bathyal } \\
\text { depths. }\end{array}$ & --- \\
\hline R9 & Monterey & $\begin{array}{l}\text { Dentalina pseudoobliqua Finger and } \\
\text { Lipps, Gyroidina relizana Klein- } \\
\text { pell, Pullenia miocenica Klein- } \\
\text { pell, Siphogenerina branneri } \\
\text { (Bagg), Valvulineria californica } \\
\text { Cushman. }\end{array}$ & $\begin{array}{l}\text { Middle Miocene, } \\
\text { early Luisian } \\
\text { Stage. }\end{array}$ & $\begin{array}{l}\text { Upper middle bathyal } \\
(500-1,500 \mathrm{~m}) .\end{array}$ & $\begin{array}{l}\text { Assemblage also includes Denta- } \\
\text { lina quadrulata (Cushman and } \\
\text { Parker), Planulina baggi Klein- } \\
\text { pell, and Plectofrondicularia } \\
\text { californica (Cushman and } \\
\text { Stewart); these taxa are more } \\
\text { common in, but not restricted } \\
\text { to, the early Miocene, suggest- } \\
\text { ing that the assemblage in this } \\
\text { sample may be older than the } \\
\text { assemblages in samples } 7 \text { and } 8 .\end{array}$ \\
\hline
\end{tabular}


Table 2.-Age-diagnostic taxa, ages, and paleobathymetry of benthic foraminifers from outcrop samples of Miocene marine sedimentary strata in the southwestern Santa Clara Valley and vicinity, Calif-Continued.

\begin{tabular}{|c|c|c|c|c|c|}
\hline $\mathrm{R} 10$ & Monterey & $\begin{array}{l}\text { Globobulimina pseudotorta (Cush- } \\
\text { man), Pullenia miocenica Klein- } \\
\text { pell, Valvulineria miocenica } \\
\text { Cushman. }\end{array}$ & $\begin{array}{l}\text { Middle Miocene, } \\
\text { Luisian Stage. }\end{array}$ & $\begin{array}{l}\text { Upper bathyal (150- } \\
500 \mathrm{~m}) \text {, with trans- } \\
\text { port from inner shelf. }\end{array}$ & $\begin{array}{l}\text { Sample collected from probable } \\
\text { overturned beds. }\end{array}$ \\
\hline R13 & Monterey & Barren of benthic foraminifers ------- & ------------------ & & . \\
\hline R16 & $\begin{array}{l}\text { Probable } \\
\text { Monterey }^{2}\end{array}$ & do -------------------- & & & \\
\hline
\end{tabular}

${ }^{1}$ Mapped as Temblor Formation by Bailey and Everhart (1964).

${ }^{2}$ Mapped as unit Tsh by McLaughlin (1971).

1993). The marine Merced(?) Formation is overlain by, and may interfinger with, the nonmarine Santa Clara Formation (Addicott, 1969; Pampeyan, 1993). Marine strata correlative with the Merced(?) Formation may occur in the subsurface beneath San Francisco Bay and the southwestern Santa Clara Valley but were not recognized in the wells studied for this report. The Merced(?) Formation near Palo Alto is thought to have been deposited in marine waters that were connected to the Pacific Ocean by way of an embayment which included the type Merced Formation near Mussel Rock (Addicott, 1969).

\section{Pliocene and Quaternary Nonmarine Strata}

Pliocene and younger nonmarine strata, which are widespread in surface outcrops and in the subsurface of the southwestern Santa Clara Valley, include the Pliocene and Pleistocene Santa Clara Formation and overlying, unnamed Quaternary deposits (figs. 2, 3).

The Santa Clara Formation, which rests in angular unconformity on Miocene and older strata, consists of poorly to moderately lithified conglomerate, sandstone, siltstone, and clayey mudstone that were deposited in various nonmarine environments in response to late Cenozoic tectonism and uplift of the nearby Coast Ranges (Dibblee, 1966a,b; Cummings, 1968; McLaughlin and others, 1999). In the Saratoga area (fig. 2), for example, parts of the Santa Clara Formation were deposited on the proximal parts of alluvial fans and consist mainly of Franciscan Complex detritus derived from contemporaneous uplift and erosion of a nearby part of the Santa Cruz Mountains, whereas other parts of the Santa Clara Formation were deposited by northwestward-flowing braided streams carrying clasts of siliceous shale, "exotic" siliceous volcanic rocks, and other non-Franciscan debris (Vanderhurst and others, 1982). The Santa Clara Formation also includes intervals of fossiliferous mudrock and fine-grained sandstone that were deposited in lakes and ponds (Dibblee, 1966b; Sorg and McLaughlin, 1975; Vanderhurst and others, 1982; Adam and others, 1983; McLaughlin and others, 1991a, 1992). Most of these lacustrine intervals are less than $10 \mathrm{~m}$ thick, but some are more than $100 \mathrm{~m}$ thick (Vanderhurst and others, 1982, p. 27).

The Santa Clara Formation is late Pliocene to middle Pleistocene in age, on the basis of fossil vertebrates, freshwater mollusks, pollen, and land plants (Sorg and McLaughlin, 1975; Adam and others, 1983), whole-rock K-Ar ages on intercalated basaltic volcanic rocks (Nakata and others, 1993; McLaughlin and others, 1999), and an interbed of tuff that has been correlated with the Rockland tephra, variously dated at about 0.40 to $0.45 \mathrm{Ma}$ (Sarna-Wojcicki and others, 1985, 1991, 2000; Meyer and others, 1991; McLaughlin and others, 1999) and about 0.61 to 0.62 Ma (Lanphere and others, 1999). In its type area near Saratoga, the Santa Clara Formation is about 700 m thick (Dibblee, 1966b; Cummings, 1968; Sorg and McLaughlin, 1975; Vanderhurst and others, 1982).

The Santa Clara Formation has been penetrated by numerous boreholes beneath the flat floor of the southwestern 
Santa Clara Valley, including many water wells (Clark, 1924; California State Water Resources Board, 1955; California Department of Water Resources, 1967, 1975; Iwamura, 1995) and several old oil wells described below. In comparison with outcrop sections in the foothills, the Santa Clara Formation in the subsurface is generally better sorted and stratified, and it is so similar to the overlying Quaternary alluvial deposits that the contact between the Santa Clara Formation and the younger alluvial fill is indistinguishable (California Department of Water Resources, 1967, 1975; Iwamura, 1995). In the upland areas along the margins of the Santa Clara Valley, the Santa Clara Formation may be distinguishable from younger, lithologically similar Quaternary deposits in that the Santa Clara Formation is deformed by folding and faulting and is unconformably overlain by younger, less deformed deposits.

In the foothills along the southwestern margin of the Santa Clara Valley, the Quaternary deposits that overlie the Santa Clara Formation are generally undeformed and consist mainly of gravel and sand deposited by streams on the upper parts of alluvial fans. These coarse-grained sedimentary deposits grade downfan, toward San Francisco Bay, into finer grained, better sorted, more stratified gravel, sand, and mud that were deposited in stream channels, levees, and flood plains on the more distal parts of alluvial fans. These deposits, in turn, grade into and are interstratified with bay mud that was deposited in saltwater marshes and ponds, on tidal flats, and below the shallow waters of the bay (Helley and others, 1979). The unconsolidated alluvial fill (including the Santa Clara Formation) is more than $400 \mathrm{~m}$ thick beneath the central Santa Clara Valley (Fio and Leighton, 1995, p. 13).

The unconsolidated Quaternary deposits and the unconsolidated to weakly consolidated parts of the Santa Clara Formation, which have been penetrated by hundreds of water wells and other boreholes, are the most important groundwater-bearing units beneath the Santa Clara Valley (Clark, 1924; California State Water Resources Board, 1955; California Department of Water Resources, 1967, 1975; Iwamura, 1995). Permeable layers of coarse-grained sedimentary deposits - mainly sand and gravel associated with old stream channels - form the principal aquifers, whereas less permeable to impermeable beds of silt and clay are aquitards (Iwamura, 1995).

\section{Range-Front Fault System}

The boundary between the Santa Cruz Mountains and the southwestern margin of the Santa Clara Valley generally coincides with a complex zone of northwest-trending, northeastward-vergent thrust and reverse faults, collectively called the range-front fault system (Langenheim and others, 1997; McLaughlin and others, 1999). Individual faults within the range-front fault system include the Monte Vista, Shannon, Berrocal, and Sargent Faults, as well as several shorter, unnamed faults (figs. 1, 2). At the surface, most of these faults dip southwest (Dibblee, 1966b; McLaughlin, 1974, 1990; Sorg and McLaughlin, 1975; McLaughlin and others, 1991a, b, 1999; Kovach and Page, 1995; Angell and Crampton, 1996;
Langenheim and others, 1997; McLaughlin and others, 1999); however, the deeper structure of the range-front fault system is uncertain. At about 8-km depth or deeper, faults of the rangefront fault system may steepen and merge or become parallel with the San Andreas Fault (Angell and Crampton, 1996; McLaughlin and others, 1997b, 1999).

Uplift of the Santa Cruz Mountains was related to movement along the range-front fault system during the Pliocene and Pleistocene, coincident with deposition of at least part of the Santa Clara Formation (Vanderhurst and others, 1982; Adam and others, 1983) and with right-lateral offset along the nearby San Andreas Fault (Cummings, 1968; McLaughlin and others, 1996a). Movement along faults of the range-front fault system resulted in significant folding and faulting of strata as young as the Santa Clara Formation, which in places dips steeply, is locally overturned, and is overthrust by the Franciscan Complex and overlying Miocene strata (Dibblee, 1966b; Cummings, 1968; Sorg and McLaughlin, 1975; Hay and others, 1980; McLaughlin and others, 1999).

Alluvial fans and other geologically young deposits that overlie the Santa Clara Formation are undeformed or are much less deformed than the Santa Clara Formation, suggesting that the intensity of tectonic deformation along the range-front fault system may have decreased during the late Pleistocene and Holocene (Cummings, 1968; McLaughlin and others, 1997a, 1999). Nevertheless, some faults of the range-front fault system may have been active during late Pleistocene and Holocene time, as indicated by offsets, tilting, and warping of very young fluvial terraces and paleosols (Sorg and McLaughlin, 1975; Hay and others, 1980; Bürgmann and others, 1994; Hitchcock and others, 1994; McLaughlin and others, 1997a, b, 1999). Faults of the range-front fault system are considered to be potentially significant earthquake hazards, on the basis of geologic, geomorphic, and geodetic evidence for late Quaternary displacement, as well as historical seismicity (McLaughlin, 1974; Sorg and McLaughlin, 1975; Wesson and others, 1975; Hay and others, 1980; Bürgmann and others, 1994; Hitchcock and others, 1994; Schwartz and others, 1994; Campbell and others, 1995; Angell and Crampton, 1996; McLaughlin and others, 1996b, 1999; Langenheim and others, 1997). Surface deformation and damage to cultural features occurred along the Berrocal, Shannon, and Monte Vista Faults during the 1989 Loma Prieta, Calif., earthquake, suggesting that these faults may have slipped at depth (Haugerud and Ellen, 1990; Schmidt and others, 1996; Langenheim and others, 1997).

Contraction across the range-front fault system since about 3 Ma has caused about $3 \mathrm{~km}$ of cumulative shortening and about $3 \mathrm{~km}$ of cumulative uplift (Bürgmann and others, 1994; McLaughlin and others, 1996b, 1999). The shortening has been accommodated by movement along thrust and reverse faults and by folding. Apatite fission-track ages indicate that the uplift has occurred at an average rate of about $0.8 \mathrm{~mm} / \mathrm{yr}$ since about 4.6 Ma (Bürgmann and others, 1994; McLaughlin and others, 1997a). Steep drainage slopes and high topographic relief provide additional evidence for geologically recent uplift (Bürgmann and others, 1994). 
The amount of right-lateral slip along faults of the rangefront fault system is unknown but may be large (McLaughlin and others, 1996b, 1999). Some of these faults approximately parallel the right-lateral San Andreas Fault and are affected by the same tectonic stress regime, and so they may have components of right-lateral displacement (Hay and others, 1980; Angell and Crampton, 1996; McLaughlin and others, 1999). Consistent with this hypothesis, geodetic measurements indicate that a section of the Sargent Fault is currently slipping right laterally at a rate of about $3 \mathrm{~mm} / \mathrm{yr}$ (Prescott and Burford, 1976). Furthermore, in some localities, the faults exhibit slickensides and other kinematic indicators showing both right-lateral and reverse slip (McLaughlin and others, 1999). However, the total amount of right-lateral offset along the range-front fault system remains unascertained because no piercing points (Crowell, 1959) — such as offset submarine fans, volcanic centers, or shorelines-have been identified.

Movement along the range-front fault system and concurrent uplift of the Santa Cruz Mountains are attributable to both local and regional causes, including (1) local horizontal compression at a nearby left (restraining) bend along the San Andreas Fault (Bürgmann and others, 1994; Schwartz and others, 1994) and (2) regional transpression (oblique convergence) along the Pacific-North American Plate boundary since about 3.5 Ma (Page and Engebretson, 1984; Harbert and Cox, 1989; Sébrier and others, 1992).

\section{Gravity Evidence for a Concealed Sedimentary Basin Beneath the Southwestern Santa Clara Valley}

Northwest of the range-front fault system, gravity data indicate the presence of a concealed sedimentary basin beneath the southwestern Santa Clara Valley (Robbins, 1971; Roberts and Jachens, 1993; Jachens and others, 1995). A conspicuous isostatic-gravity low with a maximum value of about $28 \mathrm{mGal}$ extends about $35 \mathrm{~km}$ from Palo Alto to near Los Gatos (fig. 6). This low, called the Cupertino low by Robbins (1971, p. B130), is interpreted as a sedimentary basin containing low-density Cenozoic strata that rest on higher-density rocks of the Franciscan Complex (Robbins, 1971; Roberts and Jachens, 1993; Jachens and others, 1995; Stanley and others, 1996).

A thickness map based on the gravity-modeling technique of Jachens and Moring (1990) indicates that the subsurface sedimentary basin trends northwest, is asymmetric, and is more than $3 \mathrm{~km}$ thick (fig. 7). The basin fill is thickest in the southwestern part of the basin and thins gradually northeastward over a distance of about $10 \mathrm{~km}$. The steep southwestern basin margin is probably fault controlled; below, we present some alternative interpretations of the faulted basin boundary.

The stratigraphy of the subsurface sedimentary basin represented by the Cupertino low is poorly known because no wells have penetrated its entire maximum thickness of about $3 \mathrm{~km}$. However, lithologic logs from exploratory oil wells around the margins of the basin, as discussed in detail below, demonstrate that at least the uppermost $800 \mathrm{~m}$ of the low-density basin fill consists of Miocene and younger strata.

\section{Oil Exploration in the Los Gatos Area}

About 1861, only 2 years after E.L. Drake drilled the world's first oil well in Pennsylvania (Levorsen, 1967), small amounts of oil were discovered in streams, springs, and water wells in the Santa Cruz Mountains in the vicinity of Moody Gulch, about $6.5 \mathrm{~km}$ south of the Los Gatos Post Office (fig. 5; Bruntz, 1971, p. 20-21). An intense search for oil ensued, resulting in the drilling of many wells and establishment of the Moody Gulch oil field (fig. 1). By 1890, 10 producing wells had been drilled at Moody Gulch, from which about 10 barrels of oil per day were pumped (Watts, 1890, p. 606). The Moody Gulch oil field, however, never met expectations, and it was abandoned about 1938 (Krueger, 1943; Bruntz, 1971, p. 22) after producing a total of about 98,000 barrels of oil and 44 million $\mathrm{ft}^{3}$ of gas (California Division of Oil, Gas, and Geothermal Resources, 1996).

In 1891, one of the Moody Gulch drillers, R.C. McPherson, found oil in a well along San Jose Road (now Los Gatos Boulevard) in the Santa Clara Valley flatlands, about 3 km northeast of the Los Gatos Post Office (fig. 5; Bruntz, 1971, p. 21). The record is unclear as to whether the initial discovery was made on property belonging to McPherson, as implied by McLaughlin and Waring (1914, p. 470), or on the H.H. Main property, as reported by Bruntz (1971, p. 21). Between 1891 and 1929, about 20 wells were drilled for oil and gas in and near Los Gatos (table 1; see detailed descriptions below). Several of these wells recorded shows of oil and (or) gas, mainly in shale and sandstone of the Miocene Monterey Formation. Although commercial production was never established (Huguenin and Castello, 1921, p. 206), small amounts of oil were produced for use as fuel, lubricant, and road tar by local residents (Crawford, 1896, p. 585; McLaughlin and Waring, 1914, p. 470; D.A. Peck, oral commun., 1994). Contemporary geologic reports (McLaughlin and Waring, 1914, p. 470; Vander Leck, 1921, p. 64) mentioned the Monterey Formation by name and stated that the principal drilling objectives were oil-bearing rocks within that formation.

Most exploratory oil wells in the Los Gatos area were drilled with cable tools rather than rotary rigs as used in modern drilling. Cable-tool drilling involves repeated dropping of a sharpened cutting tool to pound a hole into the earth (Rintoul, 1978, p. 21-29). In California during the late 19th and early 20th centuries, a cable-tool drill string consisted of a heavy bit suspended by a cable from a wooden derrick. Power to lift the drill string was furnished by a steam engine. The bit was repeatedly raised and dropped; as the bit hammered its way into the earth, it pulverized the soil and rocks. From time to time, the drill string was pulled out, water was dumped into the hole, and the resulting slurry of drill cuttings was removed by bailing. The bailer was a long piece of pipe lowered into the hole on another, smaller cable. On the bottom of the bailer 
was a one-way door that opened as the bailer was dropped into the hole; the cuttings entered the bailer through this door, which closed when the bailer was reeled back up. The driller examined the pieces of rock in the bailer and made notes that constitute the driller's log. Several of the driller's logs from wells in the Los Gatos area are handwritten originals that vary in legibility. Some driller's logs are quite detailed, whereas others are generalized, and a few have additional problems, such as illegible penmanship, factual inconsistencies, and obvious arithmetic errors. Some driller's logs are difficult to interpret because they use such archaic jargon as "shell" (an interval of hard drilling; see Watts, 1890, p. 607) and "sticky blue" (probably a clay-rich interval). No geophysical logs (electrical, acoustic, dipmeter, and so on) are known from wells in the Los Gatos area, nor is any paleontologic information available. We do not know whether any lithologic samples from wells in the Los Gatos area have survived to the present.

\section{Forstner's Map}

An undated, apparently unpublished map entitled "Geological Sketch Map of Oil Field near Los Gatos, Santa Clara County, Calif., to Accompany Report by W. Forstner," is here reproduced as figure 8 . This map is important because it depicts oil wells and surface occurrences of petroleum that can

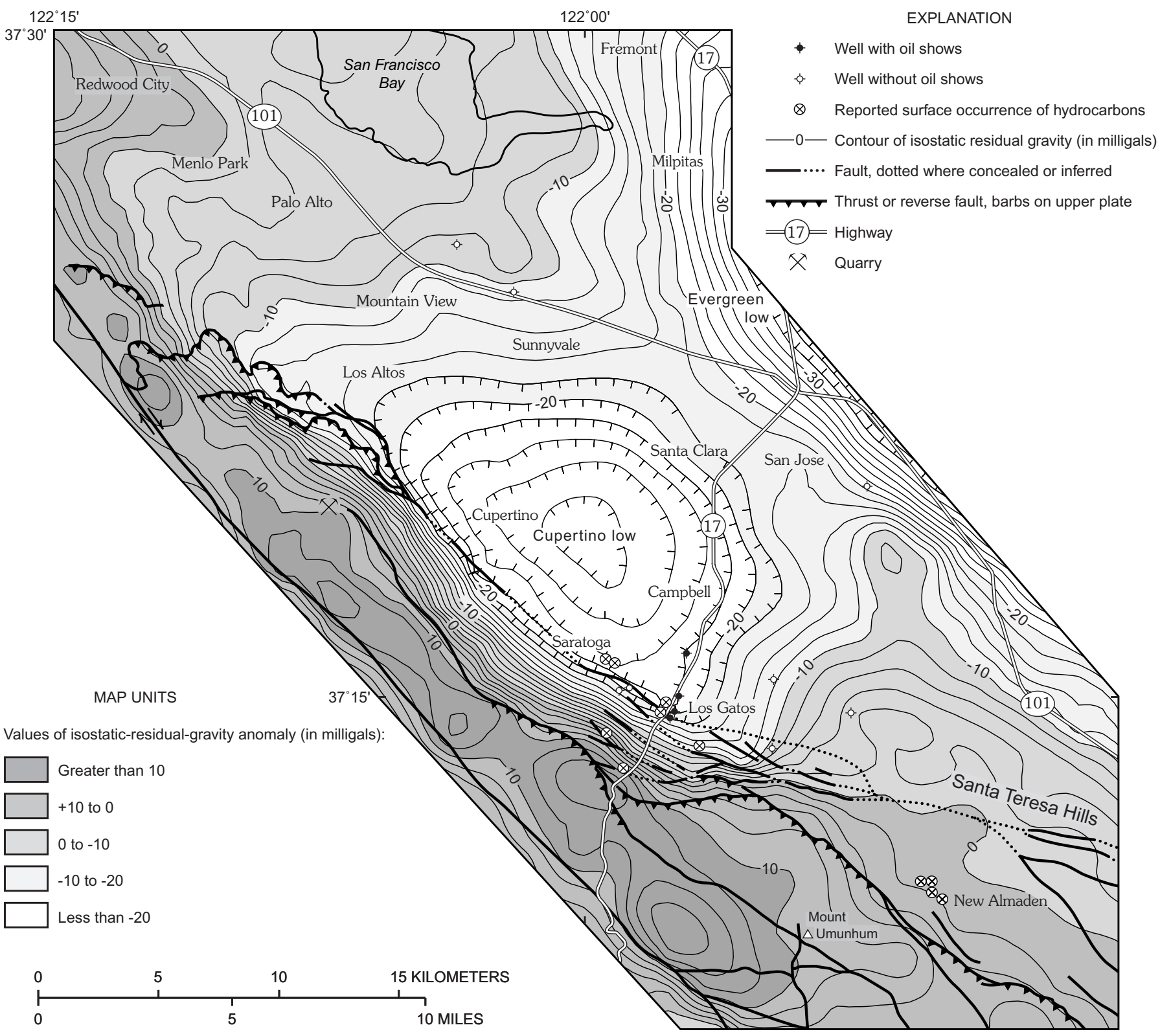

Figure 6.-Generalized gravity map of the southwestern Santa Clara Valley and vicinity, Calif. (fig. 1). Gravity data from Snyder and others (1982), augmented with approximately 300 additional observations made after 1982. Gravity anomalies are shown as isostatic-residual-gravity anomalies (Jachens and Griscom, 1985) to emphasize anomalies caused by near-surface density distributions. 


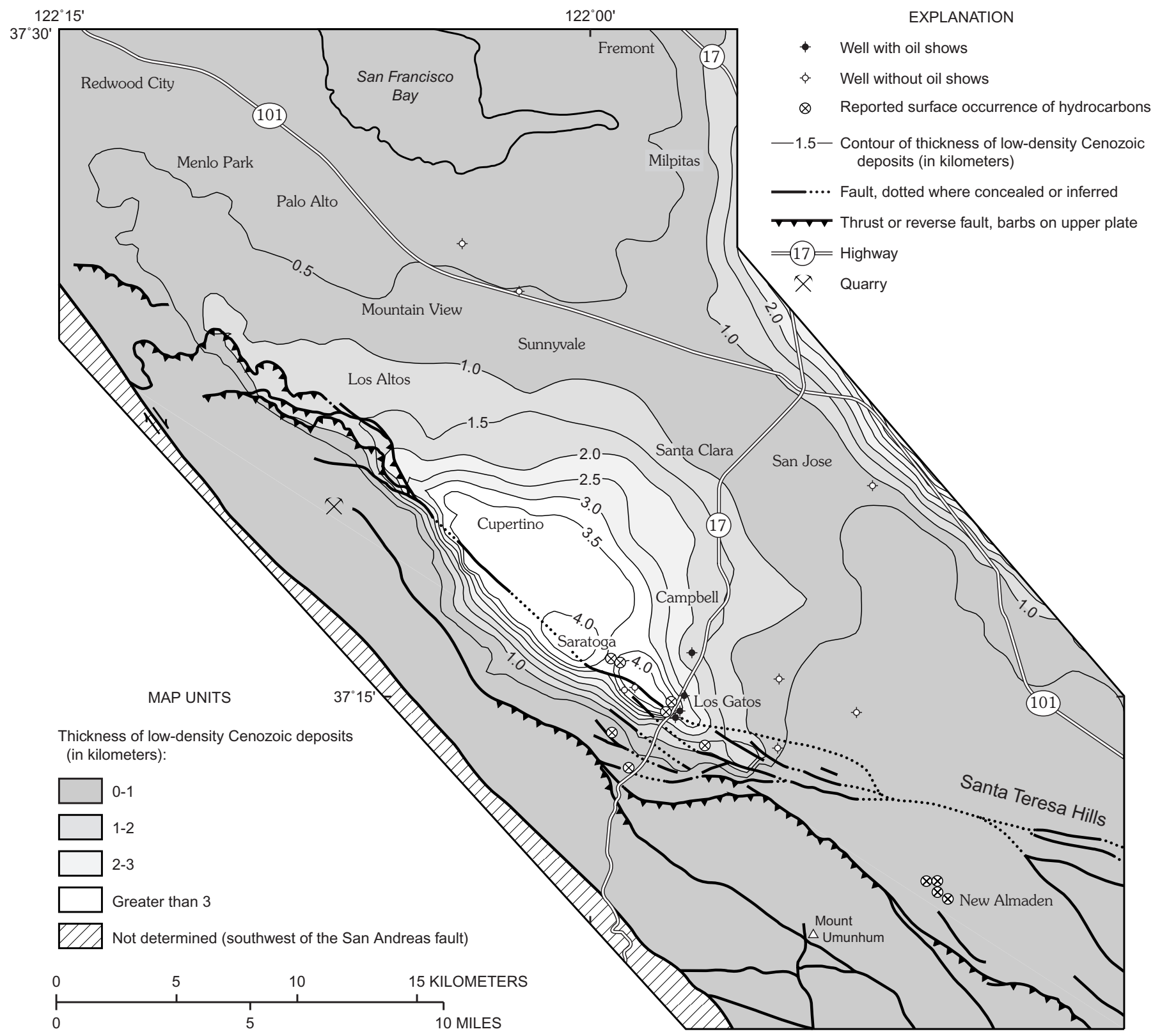

Figure 7.- Thickness map of low-density Cenozoic deposits in the southwestern Santa Clara Valley and vicinity, Calif. (fig. 1), from a three-dimensional inversion of gravity data constrained by outcrop geology, wells that penetrate underlying basement rocks, and density logs from drill holes. In this procedure (Jachens and Moring, 1990), gravity field is partitioned iteratively into one component caused by density variations within basement rocks and another component reflecting low-density basin deposits. "Basin" component of gravity field is then inverted to estimate thickness of Cenozoic deposits, based on three-dimensional-grid calculations (grid size, 0.5 by $0.5 \mathrm{~km}$ ) of the following layered-density model:

$\begin{array}{cc}\text { Depth }(\mathrm{km}) & \text { Density }\left(\mathrm{g} / \mathrm{cm}^{3}\right) \\ 0.0-0.3 & 2.12 \\ .3-1.3 & 2.22 \\ 1.3-2.3 & 2.34 \\ 2.3-3.3 & 2.47 \\ >3.3 & 2.57\end{array}$

Densities of Cenozoic deposits are based on density logs from NASA Ames Research Center Well No. 1 and deep oil wells in the San Francisco Bay region east of the San Andreas Fault (Brocher and others, 1997). 
no longer be located and, so far as we know, are not recorded elsewhere. Its author may have been William Forstner, a California geologist who published a series of reports on mining and petroleum geology during the early 20th century (for example, Forstner, 1903, 1904, 1907a, b, 1908a, b, 1909a-c, 1910, 1911). Forstner's map apparently accompanied a report that is now lost; no such map or report is cataloged in the libraries of the U.S. Geological Survey, the California Division of Mines and Geology, the University of California, Stanford University, Santa Clara County, or the town of Los Gatos.

Although Forstner's map (fig. 8) is undated, the following information suggests that it was prepared sometime between 1904 and 1918. The map depicts, and so probably postdates, the following features: (1) the City Water Co. Reservoir (also known as the Seven Mile Reservoir) built by the San Jose Water Co. in 1870 (Bruntz, 1971, p. 69); (2) the Southern Pacific Railroad line into Los Gatos (SPRR, fig. 8), which was begun in June 1894 and completed in September 1895 (Bruntz, 1971, p. 39); and (3) the Interurban Railroad, which was completed early in 1904 and abandoned in March 1933 (Bruntz, 1971, p. 44-45). The map does not show, and so probably predates, the two Traders Oil Corp. wells that were drilled in 1918-20 (figs. 5, 8; table 1). Oddly and inexplicably, the map does not depict the three Main Estate wells that were drilled in 1891-97 (table 1), nor does it show some other wells believed to have been drilled in Los Gatos before 1918, including the Suburban Oil Co. and Roanoke Oil Co. wells described below.

For the five wells whose locations are shown on Forstner's map (fig. 8), little information is available on their depths, histories, or geology. Some of these wells may have been drilled for water rather than oil. The exact locations of the wells also are somewhat uncertain; the following estimates were made by comparing Forstner's map with modern 1:24,000-scale topographic maps of the Los Gatos and San Jose West 7.5-minute quadrangles. One well was located on the south side of Pollard Road, about 1,500 ft east of its intersection with Quito Road; this well evidently penetrated a "tar sand at $30 \mathrm{ft}$ as claimed by Piper" (probably Thomas A. Piper, a promoter and driller mentioned in several places below). The "well of Marion" was apparently located just northeast of the modern intersection of Bicknell Road and More Avenue. The "well of S.G. Kearney" was probably located near the present-day intersection of Bicknell Road and Smith Creek Drive. The "old oil well" was located on the northeast flank of Blossom Hill, possibly about 120 m northwest of the present-day intersection of Harwood Road and Belridge Drive; this well may be the same as El Capitan Well No. 1 described below. Finally, the "Piper oil well" was apparently located just west of the modern intersection of Los Gatos Boulevard and Garden Lane, about 150 m northeast of the Peck well (fig. 5). Forstner's map was accompanied by a nearly illegible, apparently incomplete structural cross section that shows the "Piper oil well" with a total depth of about 1,650 ft and an interval of sandstone(?) labeled as "producing" (possibly an exaggerated description of oil shows) at about 1,225- to 1,475-ft depth. The "Piper oil well" may subsequently have been deepened and renamed T.A.P. Oil Co. Well No. 1, which (as detailed below) reached a total depth of 2,035 ft and had oil shows at many intervals from 380- to 1,974-ft depth (fig. 9A; table 1). Alternatively, these two wells may have been two different boreholes.

Although Forstner's map (fig. 8) shows at least four, possibly as many as six, surface occurrences of petroleum in the Los Gatos area, we were unable to locate any of them in the field. One such locality, labeled "sand with bitumen," is about $1.7 \mathrm{~km}$ northwest of the Los Gatos Post Office (fig. 5), near the present-day intersection of Saratoga-Los Gatos Road with Lexington Drive in Monte Sereno. Of three localities that are marked by crosses and labeled "bitumen as claimed by Piper," one is in a residential area just north of the Vasona Dam, which was built in 1935 (California Department of Water Resources, 1993, p. 74); a second is now apparently submerged beneath the Vasona Reservoir; and a third is in a densely vegetated area along present-day Shady Lane, about $3.3 \mathrm{~km}$ northeast of the Los Gatos Post Office. Two other localities, marked by unlabeled crosses, north of Pollard Road near El Quito Creek (now called San Tomas Aquinas Creek), may represent additional-but unverified-surface occurrences of petroleum.

\section{Descriptions of Exploratory Wells}

\section{Sources of Information}

Information on wells in the southwestern Santa Clara Valley (tables 1, 3) was obtained from published sources and from unpublished files available for public inspection at the Santa Maria and Sacramento offices of the California Division of Oil, Gas, and Geothermal Resources (CDOGGR). Much of the available information on well locations, drilling histories, oil and gas shows, and geology is summarized in table 1 and the discussions below. The locations of most of these wells are uncertain, owing to incomplete and (or) conflicting information. Accurate locations are available only for Traders Oil Corp. Well No. 2, NASA Ames Research Center Well No. 1, the U.S. Geological Survey (USGS) coreholes, and the Peck well (table 1). Similarly, the exact dates of drilling and completion of several wells are uncertain and apparently lost. As noted above, lithologic information on wells drilled in the Los Gatos area is derived from driller's logs that vary in content and readability. Finally, we caution that some of the reported oil shows may have been exaggerated by hopeful drillers and promoters.

\section{Wells Drilled on the H.H. Main Property}

In April 1891, R.C. McPherson drilled an oil well on the H.H. Main property, about $3 \mathrm{~km}$ northeast of the Los Gatos Post Office (fig. 5; Bruntz, 1971, p. 21). According to the Los Gatos News (April 10, 1891), the well could pump an estimated 10 to 20 barrels of oil per day and was a popular attraction for Sunday drivers. The H.H. Main property was 


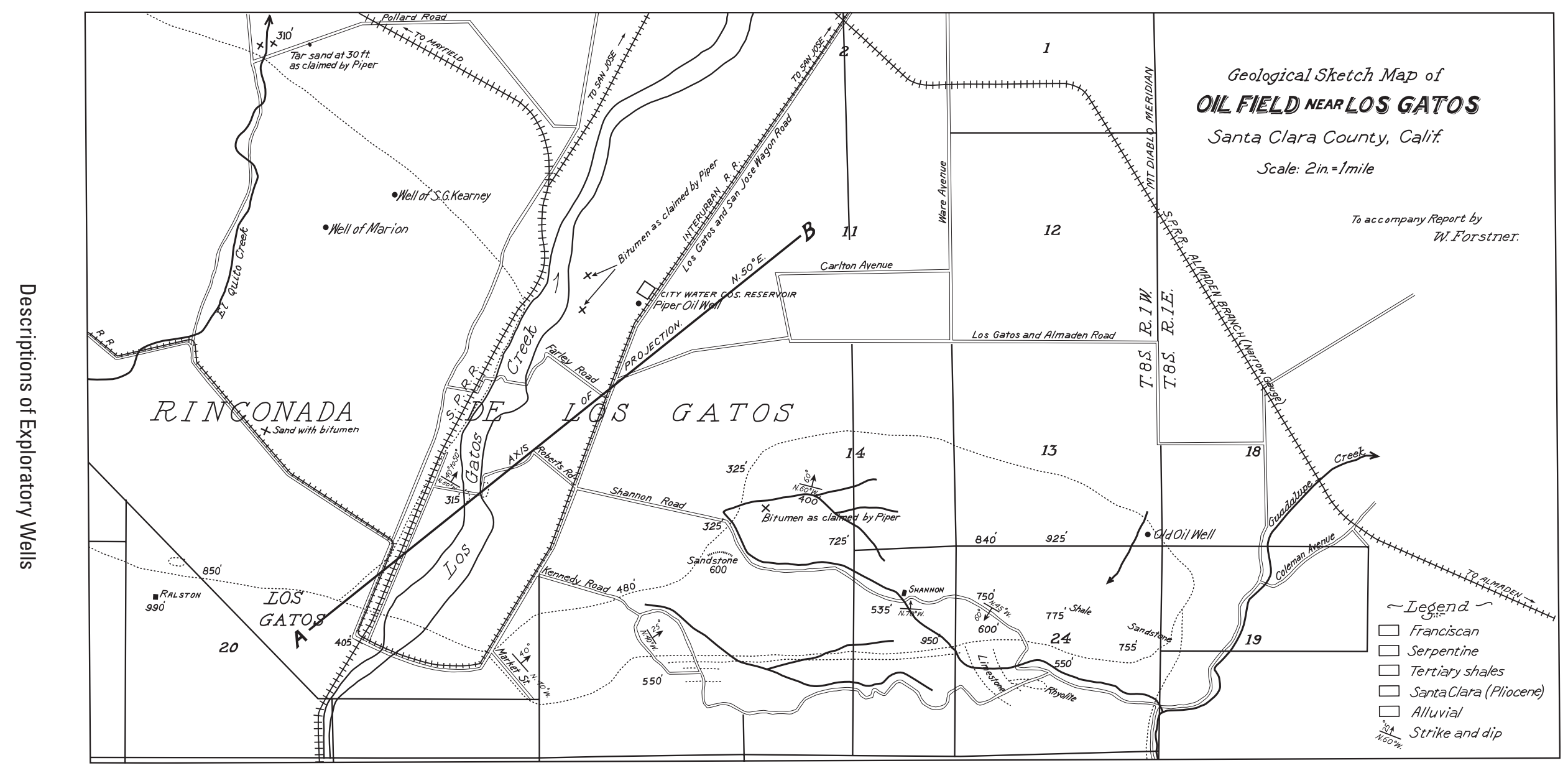

Figure 8.-Part of an unpublished, undated, and apparently unfinished map of the Los Gatos area, southwestern Santa Clara Valley, Calif. (fig. 1), by W. Forstner. Some map symbols are not explained, and geology appears to be incomplete. Map was prepared by Zenon Valin of the U.S. Geological Survey, who scanned a photocopy of original blueline (from the Santa Maria office of the California Division of Oil, Gas, and Geothermal Resources), using an Ideal model FSC-8000 scanner at a resolution of $170 \mathrm{dpi}$. File was saved as a TIFF image and opened in Adobe Illustrator to be used as a template. Linework and text were created by using pen tool, and strokes of various widths were used to trace over elements of map to preserve original line weights. 
located near the modern intersection of Garden Lane and Los Gatos Boulevard, as shown on a contemporary property map of Santa Clara County (Herrman and Herrman, 1890).

Three oil wells on the H.H. Main property were described by L.H. Eddy (in Watts, 1900, p. 153-154), on the basis of records obtained from R.C. McPherson. Main Estate Well No. 1 , which may be the same as the discovery well described above, was drilled to a total depth of $754 \mathrm{ft}$. Its precise location, other than being somewhere on the property (fig. 5), is unknown. From the surface to 50-ft depth, the well penetrated mostly gravel, sand, and clay that we interpret as Quaternary deposits and (or) Santa Clara Formation (fig. 9B; table 3).
From 50- to about 340-ft depth, the well penetrated mainly shale, "slate" (probably hard shale), "shell" (possibly siliceous shale, porcelanite, chert, or dolomite), and sand (probably sandstone) that we interpret as Monterey Formation. The "granitic rock" within the Monterey Formation at 212- to 260-ft depth (fig. $9 B$; table 3 ) is probably not a plutonic rock but, instead, may be coarse-grained sandstone or, alternatively, porphyritic volcanic rock like that cropping out at Lone Hill, about $4 \mathrm{~km}$ east of the H.H. Main property (see geologic map by McLaughlin and others, 1991a). From 340-ft depth to its bottom at 754-ft depth, the well penetrated various rocks that we interpret as probable Franciscan Complex and (or) Coast

A

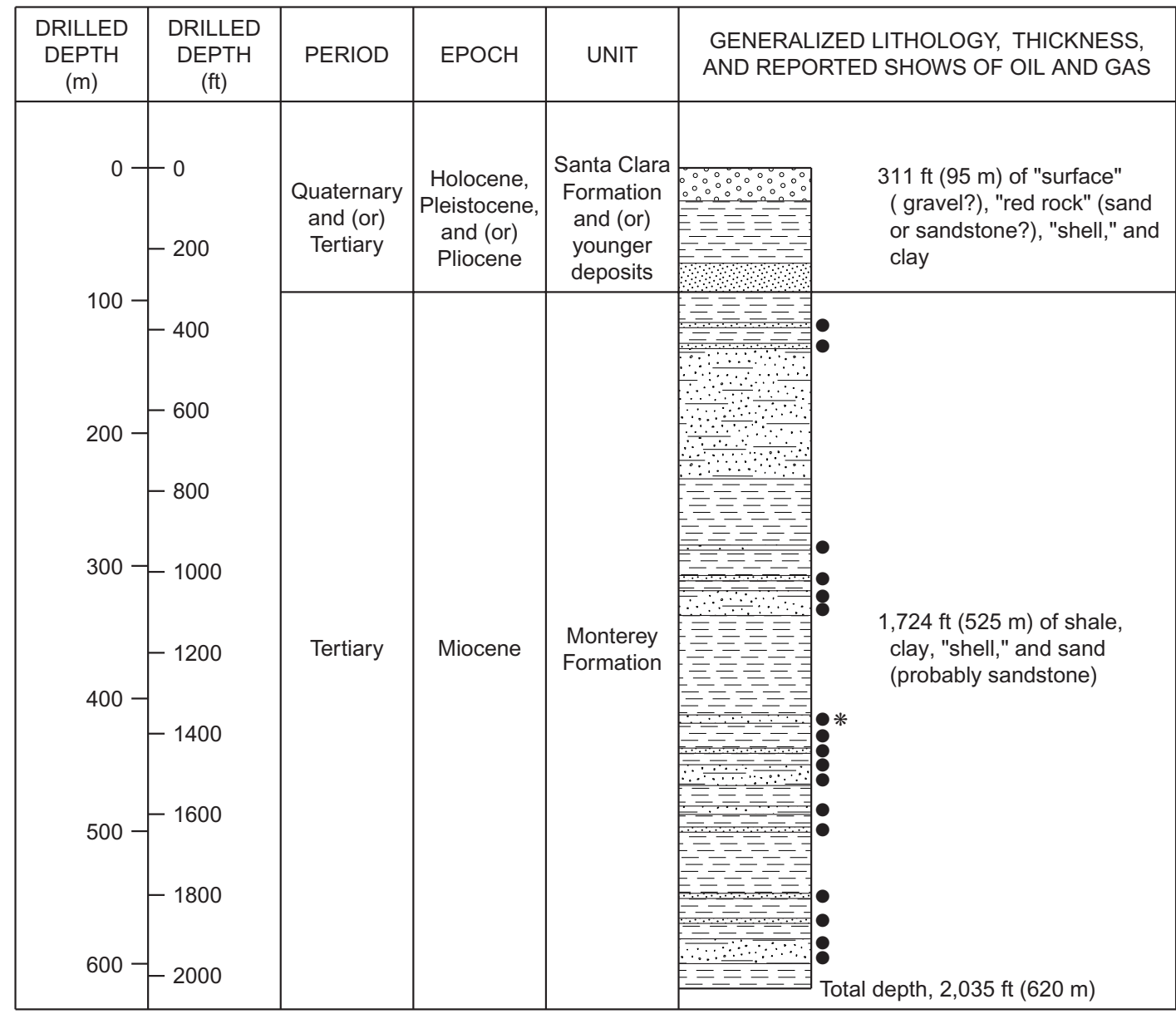

EXPLANATION

Sand and (or) sandstone
Shale, "slate," "shell," and (or) clay

Figure 9.-Generalized stratigraphic columns of T.A.P. Oil Co. Well No. $1(A)$, Main Estate Well No. $1(B)$, Suburban Oil Co. Well No. $1(C)$, and Traders Oil Corp. Wells No. $1(D)$ and $2(E)$. See table 3 for detailed lithologic logs. 
Range ophiolite, including "lime rock" (probably limestone), "soap rock" (probably serpentinite), "slate," "sand rock" (probably sandstone), and shale. Shows of oil and gas were reported from shale and sandstone of the Monterey Formation from as shallow as 83-ft depth. In addition, minor shows of gas were reported from three intervals within the presumed Franciscan Complex and (or) Coast Range ophiolite (fig. 9B; table 3). The well reportedly was lined with 10-, 8-, and 6-in. casing, but the dates and depths of the casing points were not given. This and many other Los Gatos wells were lined with casing (usually steel, but sometimes wood) to prevent sloughing and collapse of the strata surrounding the borehole.

Main Estate Well No. 2 was drilled in 1894, about $30 \mathrm{ft}$ west of Main Estate Well No. 1 (L.H. Eddy, in Watts, 1900, p. 154). The lithologic log (table 3 ) is brief and contains at least one important typographic error, and so the following stratigraphic assignments are provisional. From the surface to 119-ft depth, the well penetrated gravel, sand, and clay that we interpret as Quaternary deposits and (or) Santa Clara Formation (table 3). From 119-ft depth to its bottom at 200-ft depth, the well passed through brown shale and sand that we believe to be Monterey Formation. The composition of the "shale mixed with green rock" described at 162- to 170-ft depth is unknown. The green rock may be sandstone with glauconite or detrital serpentinite; alternatively, the well may have penetrated a fault zone or melange containing tectonically intercalated shale and serpentinite, greenstone, or altered basaltic to intermediate-composition volcanic rock. Shows of oil and gas were reported in the Monterey Formation beginning at 119-ft depth, but there is no record of any production from this well, nor any indication of the sizes and depths of casing (if any).

Main Estate Well No. 3 was drilled in 1896-97, but its precise location on the H.H. Main property is unknown. Its total depth is uncertain because drilling was still in progress at 574-ft depth when the well record was obtained (L.H. Eddy, in Watts, 1900, p. 154). From the surface to 141-ft depth, the well penetrated gravel, sand, clay, and minor shale that we interpret as Quaternary deposits and (or) Santa Clara Formation (table 3). From 141- to 180-ft depth, the well reportedly penetrated "streaks of clay mixed with sand rock"; the stratigraphic assignment of this interval is uncertain-possibly either Santa Clara Formation or Monterey Formation. From 180- to 574-ft depth, the well penetrated an interval of mostly shale and sandstone that we believe to be Monterey Formation. The "marl filled with sea shells" described from 228- to 336-ft depth and the "dark slate rock filled with sea shells" from 505- to 520-ft depth may be calcareous and siliceous shale containing fossil foraminifers, which are locally abundant in outcrops of the Monterey Formation in the Los Gatos area; alternatively, the seashells may be fossil clams and (or) other megafossils. Shows of gas and heavy oil were reported in gravel and sand at 112- to $141-\mathrm{ft}$ depth, within the interval that we interpret as Quaternary deposits and (or) Santa Clara Formation. Additional shows of oil and gas were reported below 478-ft depth in shale and sandstone of the Monterey Formation. Saltwater was

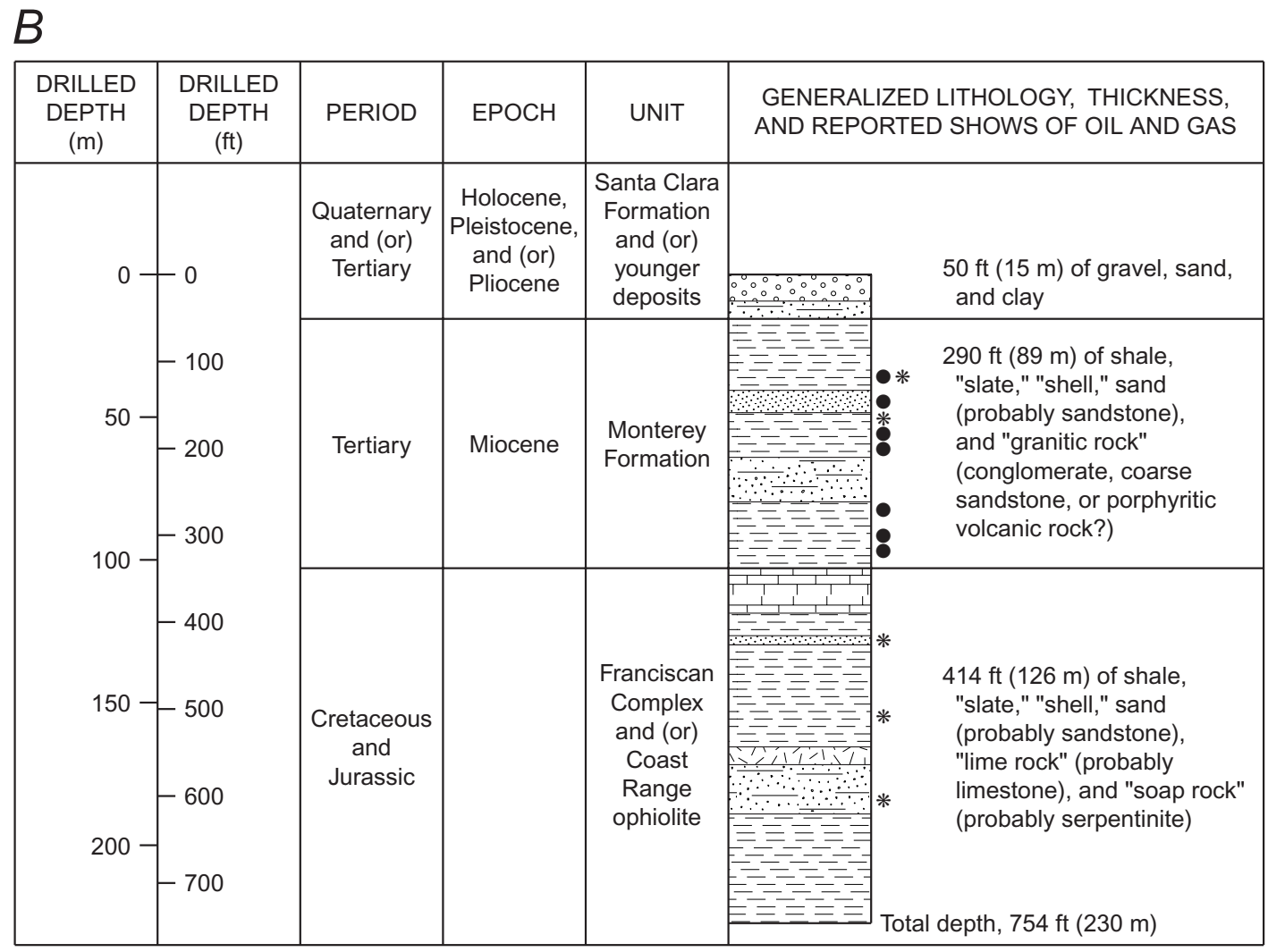

Figure 9.-Continued. 
reported from the Monterey Formation at the surprisingly shallow depth of 437 to $478 \mathrm{ft}$. At 478- to 490-ft depth, gas reportedly flowed strongly enough to raise water over the derrick. There is no record of petroleum production or casing from this well.

\section{Orchard Crude Oil Co. Well No. 4}

Orchard Crude Oil Co. Well No. 4 is known only from contemporary newspaper articles. Neither this well nor any of the other three Orchard Crude Oil Co. wells that presumably preceded it are mentioned in other publications or in
CDOGGR files. The location, total depth, and geology of this well are all uncertain.

An article on the front page of the Los Gatos Mail (Nov. 27, 1902) reported that Orchard Crude Oil Co. Well No. 4 hit a pocket of gas, throwing mud and water about $120 \mathrm{ft}$ into the air, $30 \mathrm{ft}$ above the top of the derrick; the eruption reportedly lasted for more than 30 minutes. At that time, the well was at least $700 \mathrm{ft}$ deep and had recently passed through $200 \mathrm{ft}$ of "sands well laden with oil." The article goes on to name the drillers, their assistants, company officers, at least one stockholder, and the drilling superintendent, whose name is reported as $\mathrm{Mr}$. Piper-probably Thomas A. Piper, who is mentioned by Bruntz (1971) and other historical accounts of the Los Gatos oil wells.

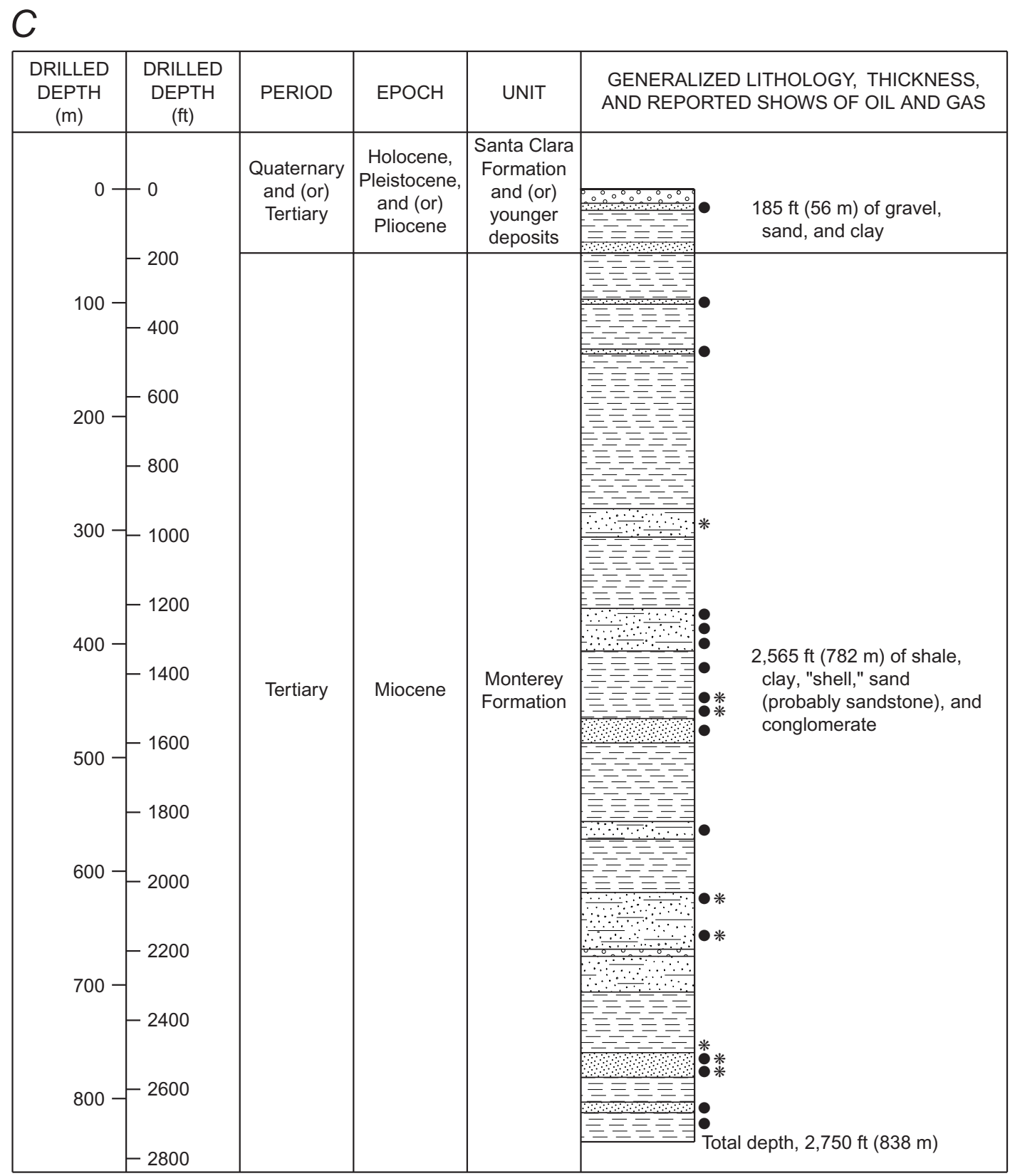

Figure 9.-Continued. 
Another front-page article in the Los Gatos Mail (Dec. 4,1902 ) reported that the well penetrated six more bodies of gas, three of which "hurled the contents of the well many ft above the derrick." A third article (Los Gatos Mail, Dec. 11,1902 ) reported that "the bailer brings up matter heavily impregnated with oil of a very high grade."

\section{Suburban Oil Co. Well No. 1}

Suburban Oil Co. Well No. 1 is known only from an unpublished handwritten driller's log in CDOGGR files. Notations on the log indicate that it was obtained "from R. Baker files" and received by the Santa Maria office of the California State Mining Bureau (CSMB, predecessor to the CDOGGR) on March 4, 1918. The date when drilling began is uncertain but must have been before November 27, 1911, when the operator started filling the hole with gravel, drill cuttings, cement, and a redwood plug.

The location of the well also is uncertain, listed only as "Lints Farm, Los Gatos, Calif." on the driller's log. Unpub- lished maps available for viewing at the San Jose office of the Santa Clara County Surveyors (including a 1929 map of Santa Clara County and some undated maps of the Los Gatos School District) show, adjacent to the old H.H. Main property, some land belonging to B.E. and P.F. Lint (fig. 5). Suburban Oil Co. Well No. 1 may have been drilled on this property; however, such a location places the well on the hanging-wall block of a mapped thrust fault, whereas the thick section of Monterey Formation penetrated by this well, as well as the absence of penetration of Franciscan rocks (see discussion below), suggests a location in the footwall block.

According to the driller's log, 12/2-in. casing was set to 473-ft depth, 10-in. casing to 1,275-ft depth, and 81/4-in. casing to 2,032-ft depth. The total depth of the well was 2,750 ft. From the surface to about 185 -ft depth, the well penetrated gravel, sand, and clay that we interpret as Quaternary deposits and (or) Santa Clara Formation (fig. 9C; table 3). From 185-ft depth to its bottom, the well penetrated mostly brown shale and "sand" (probably sandstone) that we believe to be Monterey Formation (fig. 9C; table 3). Thick intervals of "sand" occur within the Monterey Formation in the well, including

$D$

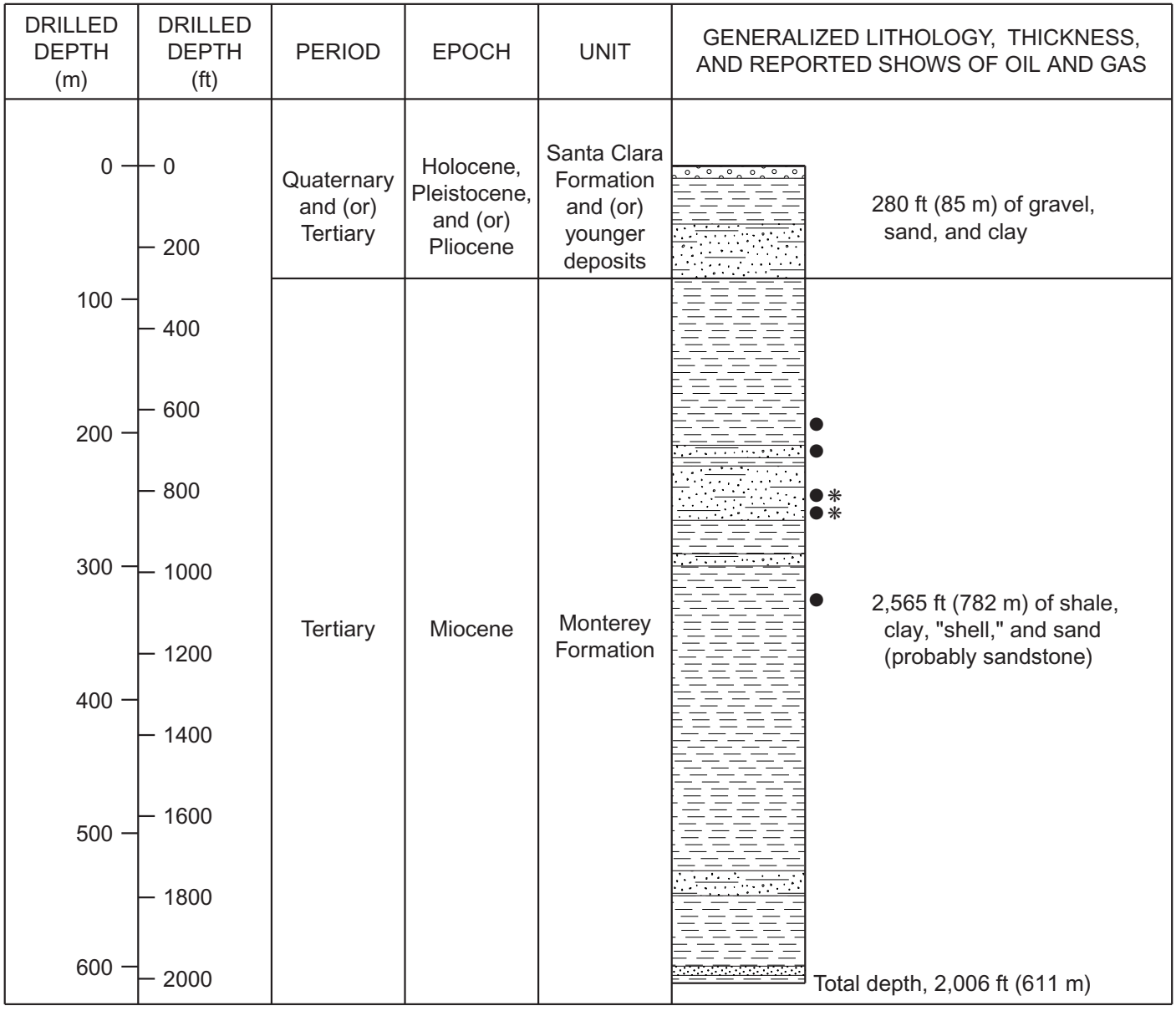

Figure 9.-Continued. 
a 15 -ft-thick interval at 1,525- to 1,540-ft depth, a 20 -ft-thick interval at 2,240- to 2,260-ft depth, a 65-ft-thick interval at 2,495- to 2,560-ft depth, and a 17-ft-thick interval at 2,652- to 2,669-ft depth (table 3 ). These thick "sand" intervals may be analogous to a sandstone interval of unknown thickness that crops out in the axis of the Blossom Hill syncline along Gumtree Drive, about $3 \mathrm{~km}$ northeast of the Los Gatos Post Office (fig. 5). A 20-ft-thick conglomerate interval at 2,190- to 2,210ft depth (table 3) may represent a debris flow or sediment gravity-flow deposit analogous to the conglomerate exposed in an outcrop of the Monterey Formation on Shannon Heights Road, about $3.6 \mathrm{~km}$ east of the Los Gatos Post Office (loc. R5, fig. 5). The meaning of the phrase "sulfur sand strong" on the driller's log at 470- to 590-ft-depth (table 3) is unclear but may refer to a pyritic sandstone or volcanic rock, or to a sandy interval containing sulfur-rich brine.

Numerous shows of oil and gas were reported from Suburban Oil Co. Well No. 1, including a 5-ft-thick oil sand in Quaternary deposits and (or) Santa Clara Formation at 45- to $50-\mathrm{ft}$ depth. Several oil sands were reported in the Monterey Formation, including a 17-ft-thick "rich oil sand" at 2,652to 2,669-ft depth (fig. 9C; table 3). Shows of oil also were reported from certain shale intervals, including those at 1,230to 1,280-, 1,445- to 1,495-, and 2,669- to 2,750-ft depth (table $3)$. Some of this oil may occur in fractured reservoirs that are broadly analogous to those reported in the Monterey Forma-

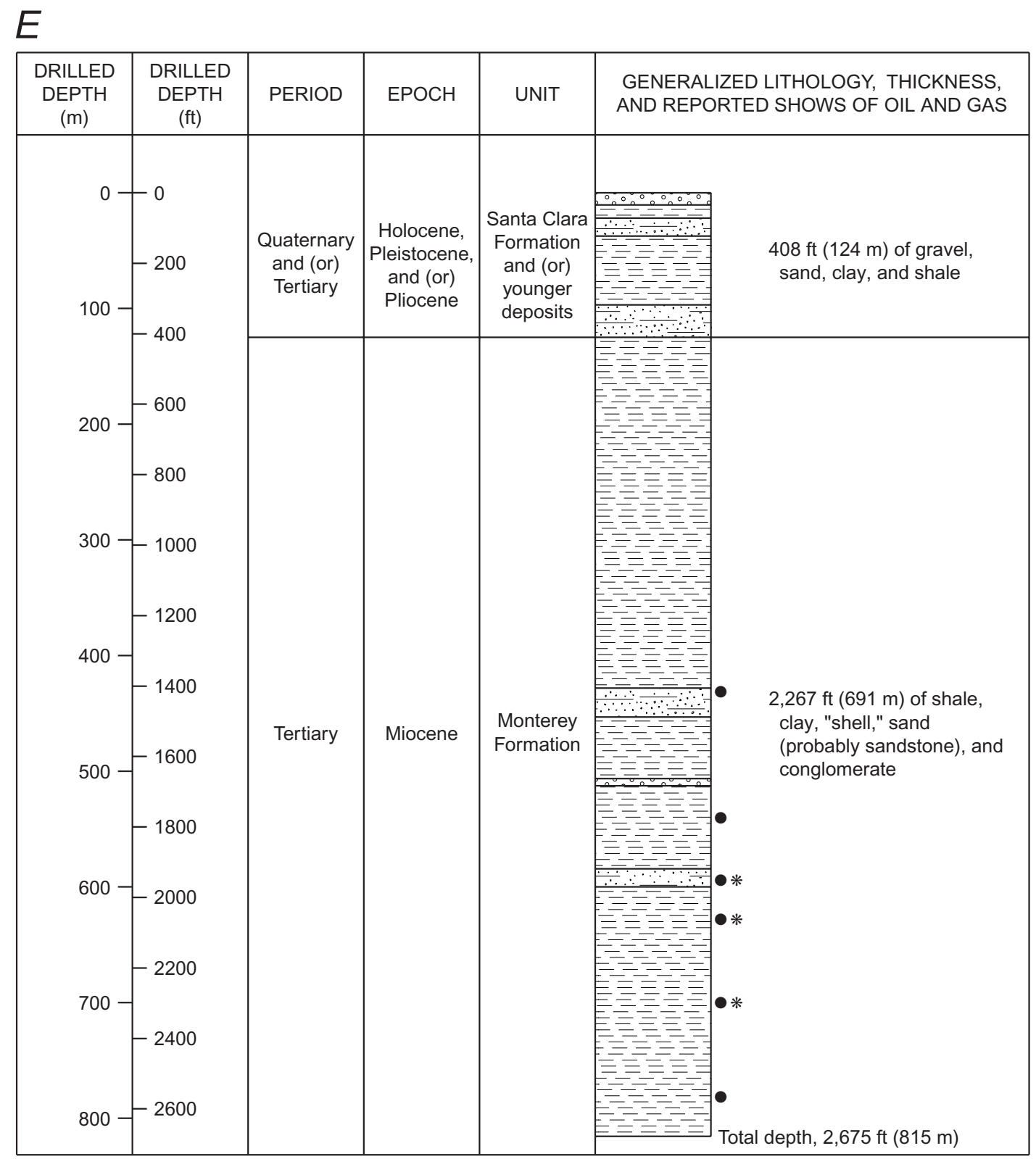

Figure 9.-Continued. 
tion elsewhere in California (for example, Regan and Hughes, 1949; Redwine, 1981; Roehl, 1981; Crain and others, 1985, 1987; Dunham and Blake, 1987). However, despite the seemingly abundant and favorable indications of oil shows, we found no indication that any oil was produced from Suburban Oil Co. Well No. 1. The observation that "sulfur water" flowed out of the hole while drilling the depth interval 1,935-2,000 ft (table 3) suggests high formation pressures within this interval.

\section{El Capitan Well No. 1}

El Capitan Well No. 1 is known only from an unpublished handwritten driller's log in CDOGGR files. Notations on this $\log$ indicate that it was obtained "from R. Baker files" and received by the Santa Maria office of the CSMB on March 4, 1918. The dates of drilling are unknown but must have been before 1918. The location of the well is uncertain; there is no mention of the property or property owner, nor any reference to Los Gatos or any other place. The origin of the name "El Capitan" is unclear; it may refer to a company or partnership, or to the location where the well was drilled. Speculatively, this well may be the "old oil well" noted on Forstner's map (fig. 8), which was located just to the west of an area labeled "Cañada de los Capitancillos" on the 1953 U.S. Geological Survey topographic map of the Los Gatos 7.5-minute quadrangle.

No information is available on the casing, production, or abandonment of El Capitan Well No. 1. Its total depth is not specified but must have been at least $800 \mathrm{ft}$. From the surface to 200-ft depth, the well penetrated "adobe" and red sand that we interpret as Quaternary deposits and (or) Santa Clara Formation (table 3). From 200- to 350-ft depth, the well penetrated light-blue shale and sandy shale of uncertain stratigraphic assignment; we tentatively assign this fine-grained interval to the Monterey Formation, although it may instead represent a fine-grained facies of the Santa Clara Formation. From 350- to at least 800-ft depth, the well penetrated an interval of mainly sandstone and shale that we interpret as Monterey Formation (table 3). Within the Monterey Formation, the well penetrated four oil sands ranging in thickness from 10 to $140 \mathrm{ft}$ (table 3), but there is no indication of any oil production.

\section{Roanoke Oil Co. Well No. 1}

Like El Capitan Well No. 1, Roanoke Oil Co. Well No. 1 is known only from an unpublished handwritten driller's $\log$ in CDOGGR files. Notations on this log indicate that it was obtained "from R. Baker files" and received by the Santa Maria office of the CSMB on March 4, 1918. The dates of drilling are unknown but must have been before 1918. The location of the well and the name of the property owner also are unknown, and there is no reference in the driller's log to Los Gatos or any other location.

According to the driller's log, 115/8-in. casing was set to 453 -ft depth and $95 / 8$-in. casing to 853 -ft depth. The total depth of the well is uncertain but must have been at least
1,017 ft. The log specifies that the well was abandoned "on account of top water," but the meaning of this phrase is unclear, and no further details were given.

From the surface to 270-ft depth, Roanoke Oil Co. Well No. 1 penetrated mainly yellow sand and blue shale that we interpret as Quaternary deposits and (or) Santa Clara Formation (table 3). From 270- to 295-ft depth, the well penetrated material described as "brown sulfur" (table 3), which may refer to pyritic shale, sandstone, or volcanic rocks within the Monterey Formation. In this well, the Monterey Formation consists mainly of dark shale with some intervals of sand. Shows of oil were noted in both sandstone and shale, including a 68-ft-thick oil sand at 382- to 450-ft depth (table 3); the driller's log notes that a failed attempt was made to establish production from this sand. Shows of gas were reported from shale at 860-ft depth and from sand at 1,017-ft depth (table 3).

\section{T.A.P. Oil Co. Well No. 1}

The existence of T.A.P. Oil Co. Well No. 1 is known only from an unpublished, handwritten driller's log in CDOGGR files. Notations on the $\log$ indicate that it was obtained "from R. Baker's files" and received by the CSMB on March 4, 1918. The dates of drilling are unknown but must have been before 1918. The identity of the operator is uncertain, but the initials "T.A.P." may be those of Thomas A. Piper, who is mentioned in several historical accounts and seems to have been an energetic promoter of oil drilling in Los Gatos during the early 1900s. The location of the well also is uncertain, given only as "Los Gatos, Calif." on the driller's log. As noted above, T.A.P. Oil Co. Well No. 1 may represent a deepening and renaming of the "Piper oil well" shown on Forstner's map (figs. 5, 8). Alternatively, these two wells may have been two different boreholes.

The total depth of T.A.P. Oil Co. Well No. 1 apparently was $2,035 \mathrm{ft}$. According to the driller's log, 12/2/2-in. casing was set to 491-ft depth, 10-in. casing to 1,486-ft depth, and $81 / 4$-in. casing to $1,992-\mathrm{ft}$ depth. From the surface to about $311-$ ft depth, the well penetrated material described as "surface," yellow clay, blue clay, shell, and "red rock" that we interpret as Quaternary deposits and (or) Santa Clara Formation (fig. 9A; table 3). From 311-ft depth to its bottom at 2,035-ft depth, the well penetrated mainly shale, sandy shale, sand, and "shell" that we interpret as Monterey Formation. We speculate that the intervals of "white sticky shale" and "whitish-blue clay" at 1,974- to 1,990-ft and at 1,996- to 2,035-ft depth, respectively, may be bentonite or other altered volcanic rocks.

Numerous shows of oil and gas were reported from the Monterey Formation in T.A.P. Oil Co. Well No. 1 (fig. 9A), including several oil sands ranging in thickness from 5 to $12 \mathrm{ft}$ (table 3). At least three times during drilling (at 1,1051,150, 1,634-1,646, and 1,966-1,974-ft depth; see table 3), formation pressures were sufficient to cause water to flow out of the borehole. However, there are no records of any oil production from this well, nor any account as to how or when the well was abandoned. 


\section{Traders Oil Corp. Well No. 1}

Traders Oil Corp. Well No. 1 (also called Traders Oil Corp. Well T-1) was drilled with cable tools in 1918 to a total depth of 2,006 ft by Traders Oil Corp. of Los Angeles. The well was a not a new borehole but a redrilling and deepening of an older well begun by T.A. Piper in 1915. In a "Notice of Intention to Deepen, Redrill, Plug, or Alter Casing in Well" dated August 8, 1918, Traders Oil Corp. proposed to deepen Piper's original well from about 1,717 to about $2,300 \mathrm{ft}$ "in an endeavor to find oil in paying quantities."

The precise location of Traders Oil Corp. Well No. 1 is uncertain, owing to incomplete and contradictory information. The original borehole may have been the "Piper oil well" shown on Forstner's map (fig. 8), but this designation seems unlikely because that well (as noted above) found a "producing" interval at about 1,225- to 1,475-ft depth, whereas the log of Traders Oil Corp. Well No. 1 reports no oil or gas shows below 1,110-ft depth, and only small shows above that depth (fig. $9 D$; table 3 ). Alternatively, the original borehole may have been the T.A.P. Oil Co. Well No. 1, but this designation seems unlikely because the driller's logs and casing records for the two wells differ in many important details (figs. 9A, 9D; table 3 ).

Confusingly, documents on file at the Santa Maria office of CDOGGR list the location of Traders Oil Corp. Well No. 1 as variously located in sec.. 8 or 10, T. 8 S., R. $1 \mathrm{~W}$ (generally in northern Los Gatos), whereas two reports (California Division of Oil and Gas, 1982b, 1991) indicate that it was in sec. 15, T. 8 S., R. $1 \mathrm{~W}$ (generally in eastern Los Gatos). Traders Oil Corp. Well No. 1 is shown as located in sec. 10, T. 8 S., R. 1 W., by Jenkins (1943, p. 660) and Davis and Jennings (1954, p. 388). A letter dated March 1, 1920, from the CSMB to the California Department of Petroleum and Gas (predecessor of the CDOGGR) states that the well was drilled on the property of Mrs. S.A. Main, but Vander Leck (1921, p. 64) and several unpublished documents in CDOGGR files indicate that it was drilled on the McGrath Ranch. An unpublished 1914 map of Santa Clara County (available for viewing at the San Jose office of the Santa Clara County Surveyors) shows the S.M. McGrath property on the south side of Los Gatos-Almaden Road, about $1.2 \mathrm{~km}$ east of the Peck well (fig. 5) in sec. 14, T. 8 S., R. 1 W. Traders Oil Corp. Well No. 1 may have been drilled either there or on some other McGrath property not shown on this map.

The original borehole-wherever it was located - was begun by T.A. Piper on January 27, 1915. A 22-in.-diameter wooden pipe was installed to 30 -ft depth, $12 \frac{1}{2}$-in. casing to 125 - or $412-\mathrm{ft}$ depth (there is conflicting information as to the exact depth), and 10-in. casing to 1,717-ft depth. A "water sand" was penetrated at 165- to $173-\mathrm{ft}$ depth, and minor shows of oil and gas were recorded at intervals from 612- to 1,110-ft depth. Traders Oil Corp. reentered the hole during 1918 and deepened it to a total depth of 2,006 ft by December 2, 1918. No additional shows of oil or gas were recorded, and commercial production was never obtained.
The lower part of the borehole was plugged, and much of the casing removed. By December 29, 1918, the borehole was completed as a water well, with $81 / 4$-in. casing set to 177 -ft depth.

From the surface to 280-ft depth, Traders Oil Corp. Well No. 1 penetrated gravel, sand, sandy clay, and clay that we interpret as Quaternary deposits and (or) Santa Clara Formation (fig. 9D; table 3). From 280 -ft depth to its bottom at 2,006-ft depth, the well penetrated mainly brown shale, "blue clay," and sand that we interpret as Monterey Formation. The rocks at the bottom were previously reported as Miocene (Davis and Jennings, 1954, p. 388; California Division of Oil and Gas, 1982b, p. 66), but the basis for this age assignment is unclear.

\section{Traders Oil Corp. Well No. 2}

Traders Oil Corp. Well No. 2, also known as Traders Oil Corp. Well No. 2 Rasmussen, was drilled with cable tools to a total depth of 2,675 ft. The well was located in Los Gatos near the present-day intersection of Lark Avenue (formerly Walker Avenue) and California Highway 17 (fig. 5). The well was previously and incorrectly reported by the California Division of Mines (1943, p. 660) and Davis and Jennings (1954, p. 388) as located in sec. 1, T. 11 S., R. 4 E., about 8 $\mathrm{km}$ east of Gilroy in southern Santa Clara County.

Traders Oil Corp. Well No. 2 was drilled as a wildcat well specifically to find commercial oil production, which the operator estimated before drilling to be at about $600-\mathrm{ft}$ depth. The date when drilling started is uncertain but probably was in January or February 1919, because the CSMB granted approval to drill the well on January 18, 1919, and the well was $415 \mathrm{ft}$ deep by February 12, 1919. Surface casing consisting of 16-in.-diameter stovepipe was installed to 19.5 -ft depth. A "water sand," presumably containing freshwater, was penetrated at 120 - to 123 -ft depth. A $12 \frac{1}{2}$-in. casing was set to about 406-ft depth in "sticky blue shale" on February 8, 1919, and 10-in. casing to 1,210-ft depth on July 2, 1919. The well was 2,365 ft deep by September 8, 1919. Total depth of 2,675 ft was reached sometime before January 26, 1920, when Traders Oil Corp. decided to abandon the well. Much of the 10- and 12 $1 / 2$-in. casing was removed, the lower part of the borehole was plugged, and the upper part of the borehole was completed as a water well with $81 / 4$-in. casing set to $131-\mathrm{ft}$ depth.

From the surface to about $408-\mathrm{ft}$ depth, Traders Oil Corp. Well No. 2 penetrated a sequence of gravel, sand, clay, and shale that we interpret as Quaternary deposits and (or) Santa Clara Formation (fig. $9 E$; table 3). From 408-ft depth to its bottom at 2,675-ft depth, the well penetrated mainly brown shale, "shell," and sand that we assign to the Monterey Formation. Traces of oil and gas were reported in shale and sandy shale (fig. 9E; table 3), but no commercial production was recorded. The "conglomerate gravel" at 1,673- to 1,677$\mathrm{ft}$ depth may represent a debris-flow deposit similar to the one that can be observed in outcrop along Shannon Heights Road about $3.6 \mathrm{~km}$ east of the Los Gatos Post Office (loc. R5, fig. 
5). The rock unit at total depth in this well was previously interpreted as "Monterey" (Vander Leck, 1921, p. 64) and as "Miocene" (Davis and Jennings, 1954, p. 388; California Division of Mines, 1943, p. 660).

\section{Alfred Tinally Well No. 1}

On January 2, 1926, a "Notice of Intention to Drill New Well" was filed with the California State Mining Bureau by Alfred Tinally, who gave his address as the St. James Hotel in San Jose. Tinally estimated that "the first productive oil or gas sand should be encountered at a depth of about 1,700 ft, more or less." The well was located in the Cambrian Park neighborhood of San Jose (fig. 2), about $0.7 \mathrm{~km}$ north of the presentday intersection of Camden Avenue and Branham Lane, but the name of the landowner is unknown. According to Davis and Jennings (1954, p. 388), the California Division of Mines (1943, p. 660), and the California Division of Oil and Gas (1982b, p. 66), this well was abandoned in 1927 at a total depth of 2,356 ft; however, no well history or geologic information is available, nor were any oil or gas shows reported.

\section{Carl Crossen Well No. 1}

Carl Crossen Well No. 1 was drilled with cable tools during December 1928 and January 1929, to a total depth of $615 \mathrm{ft}$. All sources agree that the well was in Los Gatos, but its location is uncertain and so not shown on any maps in this report. Documents on file at the Santa Maria office of the CDOGGR state that the well was drilled on the Sarah A. Main property on San Jose Road (now known as Los Gatos Boulevard), about $60 \mathrm{~m}$ east of Garden Lane; this location seems to be the same as, or very near, that of the Peck well (fig. 5). However, the location shown on the map by the California Division of Oil and Gas (1991) is in the present-day La Rinconada Country Club, about $2 \mathrm{~km}$ northwest of the Peck well.

Apparently, Carl Crossen Well No. 1 was begun during late November or early December 1928. In a "Notice of Intention to Drill New Well” filed on November 26, 1928, Carl Crossen estimated that the first productive oil and gas sand would be penetrated at about 120-ft depth. By December 13,1928 , the well was $171 \mathrm{ft}$ deep, and 10-in. casing was set to 115 -ft depth. The well reached a total depth of $615 \mathrm{ft}$ by January 14, 1929. Shows of "very little oil" were recorded in sandy brown shale at 196- to 590-ft depth (table 3); however, commercial production was never obtained, and the borehole reportedly was abandoned "as it is for water purposes." We do not know whether it was actually completed as a water well. The depth of the water-producing interval is unclear, but it may have been a 10 -ft-thick "water sand" at 605- to 615-ft depth (table 3).

From the surface to 196-ft depth, the well penetrated "boulders," clay, sand, and shale that we interpret as Quaternary deposits and (or) Santa Clara Formation (table 3). From 196-ft depth to its bottom at 615-ft depth, the well penetrated mainly sandy brown shale that we interpret as Monterey Formation. According to Davis and Jennings (1954, p. 388), the California Division of Mines (1943, p. 660), and the California Division of Oil and Gas (1982b, p. 66), the well bottomed in rocks of "Miocene(?)" age, but the basis for this age assignment is unclear.

\section{Louise S. and Harold J. Bowen Well No. 1}

On December 5, 1935, the California Division of Oil and Gas approved a request by Victor A. Chargin, agent for Louise S. and Harold J. Bowen, to abandon an oil well on their property in San Jose near the present-day intersection of Coleman Road and Almaden Expressway (fig. 2). According to Chargin's messages, the well was drilled "some years" before 1935 to a total depth of about 800 or 1,000 ft without obtaining any shows of oil or gas. No well history or geologic information is available.

\section{Peck Well}

An existing oil well with a pump unit is located inside a fenced enclosure in the parking lot of a commercial office building at 15405 Los Gatos Boulevard, just south of Garden Lane in Los Gatos (figs. 5, 10). The well and property were purchased by Donald A. Peck during the early 1970s. Peck told us that little is known about the history, depth, or geology of the well, but he stated that oil formerly reached the surface in a sump near the well, in an area now paved over and used as a parking lot.

According to Peck, the previous owner could pump small amounts of oil from the well, but it has not produced oil for some years and is regarded as a "conversation piece." The pump unit, a Jensen Straight Lift Model No. 2DC manufactured by the Jensen Bros. Mfg. Co. of Coffeyville, Kans., appears to be operable, but there is no motor, and the horsehead is no longer connected to the polished rod. The pump unit bears the serial number "2D1033" on both the Samson post and gear reducer. Using this serial number, Charles Marler of Jensen International, Inc. (written commun., May 29,1997 ), was able to locate and provide a copy of the original sales record, which indicates that the pump was sold to an unknown customer through a dealer, Oil Tool Corp. of Long Beach, Calif., on July 25, 1947, and installed on a well that was $125 \mathrm{ft}$ deep.

Much black oily substance is noticeable around the wellhead (fig. 10), and the well casing is open to the surface. We recovered a sample of oil from the Peck well by lowering a narrow glass jar on a string through the top of the casing; suspended beneath the jar was a heavy bolt that acted as a weight to drag the jar down into the oil. The jar fell freely to the air/oil interface at depth of about $3.7 \mathrm{~m}$, where a sample of black, highly viscous oil was obtained. The organic geochemistry of this oil sample is described in the next section of this report. 

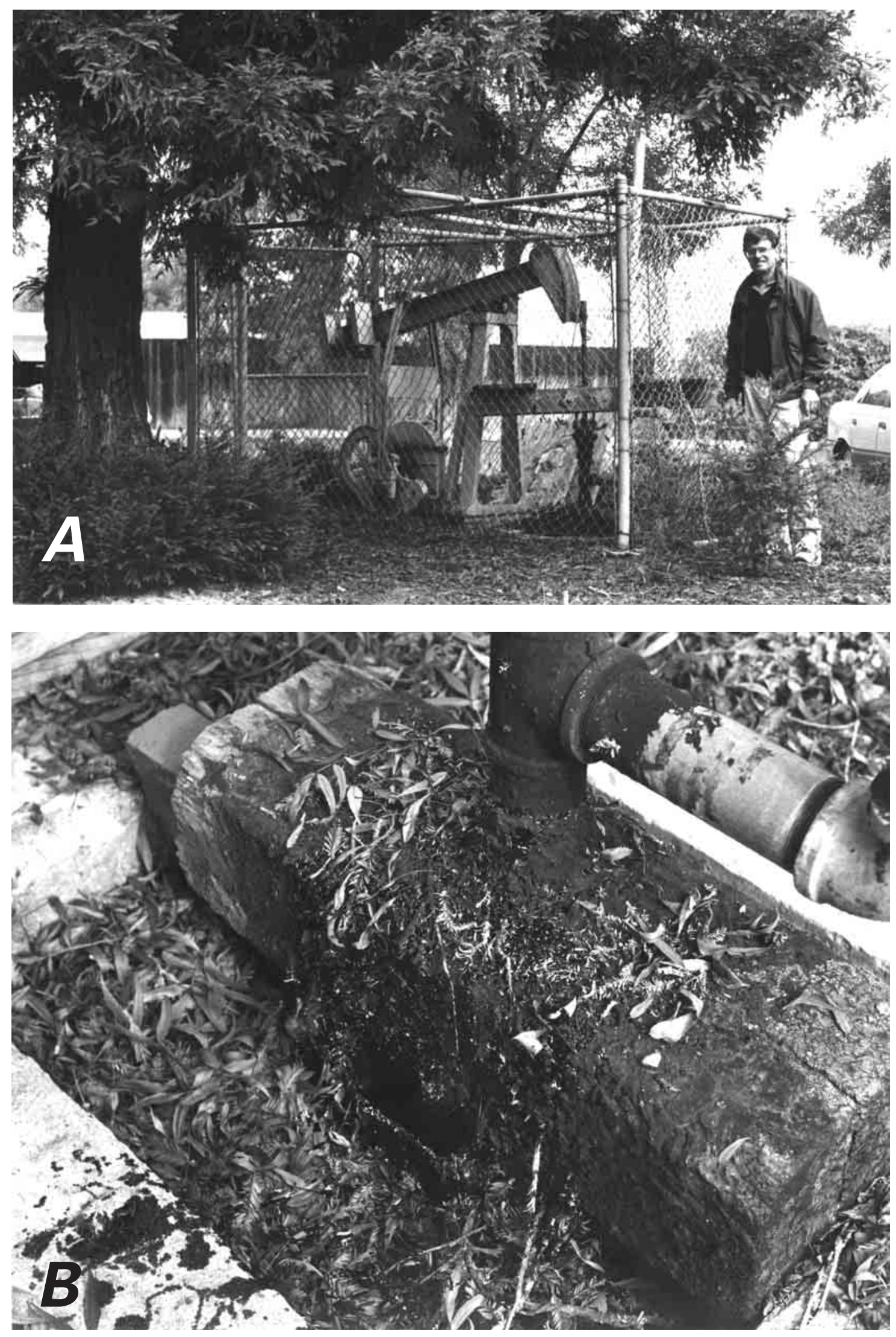

Figure 10.-The Peck well in Los Gatos, Calif. (figs. 1, 5). A, Well and pump unit within a fenced enclosure in a parking lot. $B$, Black oily substance on pipe and wooden block at wellhead; part of casing is just barely visible in center beneath wooden block. Sample of oil was obtained from about $3.7-\mathrm{m}$ depth by lowering a glass jar through narrow space between well casing and wooden block. 
The Peck well is probably the same as the "Mayem" well, which in 1953 was producing "at least" 8 barrels per day of "12.1 gravity oil," according to an undated, unpublished oil-company report provided by Henry Walrond (consulting geologist, Bakersfield, Calif.). Still unknown, however, are the identity of the original driller of the Peck well, the dates when the well was started and completed, and the stratigraphic sequence it penetrated. The Peck well may be the same as one of the other wells described earlier in this report. The well is located on the former H.H. Main property and has a pump unit designed to produce oil from $125-\mathrm{ft}$ depth, attributes more or less consistent with Main Estate Wells Nos. 1, 2, and 3, which found oil at depths as shallow as 134,119 , and $112 \mathrm{ft}$, respectively (table 3 ). The 125-ft pumping depth of the Peck well, however, is inconsistent with the shallowest reported oil shows in Carl Crossen Well No. 1 at 196-ft depth, T.A.P. Oil Co. Well No. 1 at 380-ft depth, and Traders Oil Corp. Well No. 1 at 612ft depth (table 3). Furthermore, Traders Oil Corp. Well No. 1 and, possibly, Carl Crossen Well No. 1 were reportedly completed as water wells (see discussions earlier in this report), whereas the Peck well was completed as an oil well. The Peck well is probably not the same as the "Piper oil well" shown on Forstner's map (fig. 8) because the Peck well is about $150 \mathrm{~m}$ from the reported location of the Piper well (fig. 5).

\section{USGS Coreholes in Sunnyvale and San Jose}

During 1960, the USGS drilled two coreholes, each about 1,000 ft deep, to provide information on the physical, hydrologic, and engineering properties of the sedimentary deposits in areas of the Santa Clara Valley that subsided 5 $\mathrm{ft}$ or more during the period 1934-60 (Johnson and others, 1968). Corehole 6S/2W-24C7 was located in Sunnyvale near the intersection of California Highways 101 and 237, and corehole 7S/1E-16C6 was located near downtown San Jose (fig. 2; table 1). The sedimentary deposits penetrated in both coreholes, as described in detail by Johnson and others (1968), were water bearing and mostly unconsolidated, consisting mainly of silty clay and clayey silt, with lesser amounts of sand and gravel. These strata probably represent Quaternary alluvial and bay deposits and the underlying Pliocene and Pleistocene Santa Clara Formation, but the boundary between these two units was not identified (Johnson and others, 1968, p. A8). No oil or gas shows were reported from either of the two coreholes.

\section{NASA Ames Research Center Well No. 1}

NASA Ames Research Center Well No. 1 was drilled in March 1973 by the National Aeronautics and Space Administration (NASA) at the Ames Research Center in Mountain View (fig. 2). This well was designed to provide a belowground container to store a large volume of high-pressure air that could be suddenly released into a wind tunnel (E.J. Helley, oral commun., 1994).
Modern rotary-drilling tools were used. A 15-in.-diameter hole was drilled to a total depth of either $1,415 \mathrm{ft}$ (according to the driller) or 1,427 ft (according to the wireline logger). A small suite of wireline logs-including spontaneous potential, resistivity, and compensated density-were run, and 103/4-in. casing was set and cemented to 1,345-ft depth by March 29, 1973. A borehole gravity survey (Beyer, 1980) was run on April 12-13, 1973.

No driller's log or other lithologic descriptions are available from the well, except for the observation by D.L. Wagner (oral commun., 1995) that a sample of greenstone was obtained from the bottom of the hole. No paleontologic data are available. The following tentative stratigraphic interpretations are based on (1) borehole-gravity results (Beyer, 1980; L.A. Beyer, written commun., 1995); (2) examination of available wireline logs; and (3) comparison with the stratigraphic sequence, as described above, in USGS corehole $6 \mathrm{~S} / 2 \mathrm{~W}-24 \mathrm{C} 7$, about $3 \mathrm{~km}$ southeast of NASA Ames Research Center Well No. 1 (fig. 2).

From the surface to about 1,110-ft depth, the well penetrated an interval of low-density strata that probably consists of unconsolidated to poorly consolidated clay, silt, sand, and gravel representing Quaternary alluvial and estuarine deposits and (or) the Pliocene and Pleistocene Santa Clara Formation. From 1,110- to about 1,390-ft depth is a higher-density sedimentary interval which exhibits a spontaneous-potential $\log$ response different from that of the overlying material, and may consist of Quaternary and (or) Tertiary strata—possibly including the Santa Clara Formation and (or) the Monterey Formation. We infer that the top of the Franciscan Complex and (or) Coast Range ophiolite was penetrated at about 1,390$\mathrm{ft}$ depth, on the basis of (1) abrupt and major changes in spontaneous-potential, resistivity, and compensated-density log responses; (2) a marked change in the shape of the drill hole (as shown by the caliper on the spontaneous-potential $\log$ ) from rough and irregular to smooth and even, probably reflecting a change from softer to harder material; and (3) recovery of a sample of greenstone from the bottom of the hole, as noted above. No oil or gas shows were reported from the well.

\section{Organic Geochemistry of Oils and Source Rocks}

Samples of oil from the Peck well in Los Gatos and from mercury ore collected near New Almaden (fig. 2), along with samples of potential hydrocarbon-source rocks from nearby outcrops of the Monterey Formation (fig. 4), were analyzed by the USGS organic-geochemical laboratories in Denver, Colo., and Menlo Park, Calif. Evidence from bulk oil composition, biomarkers, stable-C-isotopic $\left(\delta^{13} \mathrm{C}\right)$ composition, and Rock-Eval pyrolysis, as discussed below, indicates that (1) the oil from the Peck well is highly biodegraded (partially decomposed by microorganisms), of moderate thermal maturity, and was derived from a Miocene Monterey Formation source rock; and (2) the oil from mercury ore near New Almaden is slightly biodegraded, thermally altered, and was 
derived from an unidentified source rock of Late Jurassic age or younger and most likely of Cretaceous age.

\section{Analytical Methods}

Oils were chromatographically separated on alumina/ silica gel columns into saturated- and aromatic-hydrocarbon fractions and a nonhydrocarbon fraction by successive elution with iso-octane, benzene, and benzene/methanol. Gas chromatography of the saturated hydrocarbons was performed on a Hewlett-Packard model 5880A gas chromatograph, using a DB-1 capillary column ( $60 \mathrm{~m}$ long by $0.32 \mathrm{~mm}$ inner diameter), programmed heating (hold at $50^{\circ} \mathrm{C}$ for 2 minutes, raise temperature at $4.5^{\circ} \mathrm{C} /$ minute to $320^{\circ} \mathrm{C}$, hold at $320^{\circ} \mathrm{C}$ for 15 minutes), a splitless injector, and a flame-ionization detector. Biological-marker distributions of the oils were determined on a Hewlett-Packard model 5890 gas chromatograph/VG7025 magnetic-sector mass spectrometer by full-scan mode, parent-daughter mode (MS-MS), and selected-ion monitoring (SIM) at mass-to-charge $(\mathrm{m} / \mathrm{z})$ ratios of 191.1800, 217.1956, 231.1174, and 253.1956. The gas chromatograph used a DB-1701 capillary column (60 $\mathrm{m}$ long by $0.32 \mathrm{~mm}$ inner diameter), oncolumn injector tracking at $3^{\circ} \mathrm{C}$ above column temperature, and an oven-heating program of $50-150^{\circ} \mathrm{C}$ at $50^{\circ} \mathrm{C}$ per minute, $150-300^{\circ} \mathrm{C}$ at $3^{\circ} \mathrm{C}$ per minute, and hold at $300^{\circ} \mathrm{C}$ for 20 minutes. Sealed-tube combustions were used to prepare carbon dioxide from $\mathrm{C}_{15+}$ saturated- and aromatichydrocarbon fractions for stable-C-isotopic analysis on a Finnegan model MAT 251 isotope-ratio mass spectrometer. The results are expressed in the delta $\left(\delta^{13} \mathrm{C}\right)$ notation that represents the deviation of the ${ }^{13} \mathrm{C} /{ }^{12} \mathrm{C}$ ratio in permil (parts per thousand) relative to the Peedee belemnite (PDB) standard. S, $\mathrm{Ni}$, and $\mathrm{V}$ contents of the crude oils were determined by Huffman Laboratories, Golden, Colo.

\section{Bulk Oil Composition}

The gravity of the Peck oil is $13.4^{\circ} \mathrm{API}$, quite low in comparison with other crude oils in the region, including 16 to $40^{\circ} \mathrm{API}$ at the La Honda oil field (fig. 1), 18 to $45^{\circ} \mathrm{API}$ at the Half Moon Bay oil field (fig. 1), and $45^{\circ} \mathrm{API}$ at the Moody Gulch oil field (fig. 1; California Division of Oil and Gas, 1982a), suggesting that oil in the Peck well is biodegraded.

The S content of oil from the Peck well is 0.76 weight percent, similar to that in some other biodegraded crude oils in the area, including 0.70 weight percent in oil from the La Honda oil field (fig. 1), 0.83 weight percent in oil from the Sargent oil field (fig. 1), and 0.71 weight percent in oil from the Petaluma oil field (fig. 1; P.G. Lillis, unpub. data, 1996). Before biodegradation, the $\mathrm{S}$ content of oil from the Peck well was probably much lower and may have been comparable to that of a nondegraded-oil sample from the Half Moon Bay oil field (fig. 1), about 0.14 weight percent. The $\mathrm{S}$ contents of oil samples from mercury ore in the New Almaden area (fig. 1) range from 0.18 to 0.56 weight percent (Peabody, 1993, p. 198).
The Ni content of oil from the Peck well is 300 ppm, unusually high relative to the values of 5 to $57 \mathrm{ppm}$ measured in other local crude oils, also suggesting that the oil is biodegraded. The V content of oil from the Peck well is $7.2 \mathrm{ppm}$, higher than that of most of the other local oils, which range in $\mathrm{V}$ content from less than 0.3 to $7.2 \mathrm{ppm}$. The $\mathrm{Ni} /(\mathrm{Ni}+\mathrm{V})$ ratio, which is unaffected by biodegradation, is 0.98 in oil from the Peck well, comparable to the values of 0.89 in oil from the Sargent oil field, 0.90 in oil from the Petaluma oil field, and 0.96 in oil from the La Honda oil field (P.G. Lillis, unpub. data, 1996).

\section{Biomarkers}

Biomarkers (or biological markers) are organic compounds in crude oils and sedimentary rocks that can be linked to specific biological precursor molecules found in living organisms (Waples, 1985; Hunt, 1996). Biomarkers are essentially molecular fossils that have been used to correlate oils with their source rocks and to investigate the effects of biodegradation, thermal maturation, and other processes which influence the composition of petroleum. Two of the most commonly used suites of biomarkers are terpanes and steranes, which are monitored by gas chromatography-mass spectrometry (GC-MS) using SIM, which monitors triterpanes (including hopanes at an $\mathrm{m} / \mathrm{z}$ ratio of 191 and biodegraded hopanes or 25-norhopanes at an $\mathrm{m} / \mathrm{z}$ ratio of 177) and steranes (at an $\mathrm{m} / \mathrm{z}$ ratio of 217 ).

Gas-chromatographic data on the saturated hydrocarbons, including biomarkers, indicate that oil from the Peck well is biodegraded. The absence of $n$-alkanes and the large unresolved complex mixture (UCM) in the mass chromatogram (fig. 11A) are indicators of at least moderate biodegradation. Heavy biodegradation of the oil (Peters and Moldowan, 1993, fig. 3.62) is indicated by the dominance of a series of $\mathrm{C}_{27-32}$ 25 -norhopanes relative to the regular $\alpha \beta$-hopanes common to nonbiodegraded mature oils, as well as the high concentrations of diasteranes relative to steranes (Reed, 1977; Seifert and Moldowan, 1979). Derivation of oil in the Peck well from a Miocene Monterey Formation source rock is suggested by the low but discernible concentration of 28,30-bisnorhopane, which is common and expected in oils derived from that formation elsewhere in California (Seifert and others, 1978; Curiale and others, 1985), and by a characteristic "triplet" ratio $\left\{\left[\mathrm{C}_{26}\right.\right.$ tricyclic terpane (S-epimer) $+\mathrm{C}_{26}$ tricyclic terpane (R-epimer) $] / \mathrm{C}_{24}$ tetracyclic terpane $\left.=\sim 5-6\right\}$ that is typical of Monterey Formation oils (Kvenvolden and others, 1995).

The depth at which oil in the Peck well was generated can be estimated by measuring certain biomarker ratios believed to be a function of thermal maturity. Because the oil is heavily biodegraded, we measured only the triaromatic/ (triaromatic+monoaromatic) sterane ratio (0.7), based on the formula of Mackenzie (1984), and the triaromatic sterane "apparent" side-chain-cleavage ratio (0.06) of Lewan and others (1986). In three wells in the Salinas Basin, a triaromatic/(triaromatic+monoaromatic) sterane ratio of 
0.7 was measured on rock extracts (bitumen) obtained at about 2,130-m depth (Barwise and others, 1991). In ROCO James Well No. 1 in the Cuyama Basin, similar values of the triaromatic/(triaromatic+monoaromatic) sterane ratio and the side-chain-cleavage ratio were measured on bitumen obtained at about 2,745-m depth (P.G. Lillis, unpub. data, 1996).

Assuming that the kinetics of oil generation and the sourcerock thermal history are generally similar in the Santa Clara Valley and in the Salinas and Cuyama basins, these results suggest that oil in the Peck well was generated from source rocks at approximately 2,100-m depth, possibly as great as 2,700-m depth.

Oil from mercury ore in the New Almaden area differs considerably from oil from the Peck well. A mass chromatogram of oil from the New Almaden area (fig. 11B) shows much less UCM than that of oil from the Peck well, as well as high concentrations of $\mathrm{C}_{12-35} n$-alkanes. The presence of UCM suggests some biodegradation, whereas the presence of $n$-alkanes suggests that the oil is not heavily degraded. The cooccurrence of UCM with high concentrations of $n$-alkanes is unusual; one possible explanation is that oil from the New Almaden area is a mixture of two oils, including a biodegraded oil represented by the UCM and a nonbiodegraded oil represented by the $n$-alkanes.

Several biomarker ratios and the overall low concentrations of hopanoid and steroid biomarkers in oil from the New Almaden area suggest a high thermal maturity. The $\mathrm{S} /(\mathrm{S}+\mathrm{R}) \mathrm{C}_{29}$ sterane ratio is near the maximum "equilibrium" value of 0.52 , indicating a minimum thermal-maturity equivalent (vitrinite reflectance, $R_{0}$ ) of 0.8 percent (Peters and Moldowan, 1993). The $\beta \beta / \beta \beta+\alpha \alpha \mathrm{C}_{29}$ sterane ratio is 0.60 , approximately equivalent to an $R_{0}$ value of 0.8 percent (Peters and Moldowan, 1993). The Ts/(Ts+Tm) trisnorhopane ratio is 0.54 , approximately equivalent to an $R_{0}$ value of 0.7 percent (Peters and Moldowan, 1993). The pristane $/ n-\mathrm{C}_{17}$ ratio is 0.4 , approximately equivalent to an $R_{0}$ value of 1.2 percent (Leythaeuser and Schwarzkopf, 1986, fig. 1). The triaromatic/(triaromatic+monoaromatic) sterane ratio used on oil from the Peck well could not be measured on oil from the New Almaden area because all of the $\mathrm{C}_{26}$ and higher-molecular-weight compounds are absent and the low-molecularweight compounds are poorly resolved. Although the use of individual biomarker ratios for thermal-maturity equivalents is equivocal, oil from the New Almaden area is inferred to have an $R_{0}$ value of approximately 0.8 percent, corresponding to burial at about 3,660-m depth relative to wells in the Salinas Basin, and deeper than the 3,437-m total depth of ROCO James Well No. 1 in the Cuyama Basin. However, hydrothermal fluids associated with the mercury mineralization at New Almaden may have caused locally high temperatures that, in turn, caused oil in the New Almaden area to be generated at depths shallower than 3,660 m.

Other than the presence of minor amounts of 25-norhopanes, the biomarkers in oil from the New Almaden area do not appear to be significantly biodegraded. Oleanane is present in moderate amounts; this biomarker is derived from angiosperm land plants, and its presence suggests that oil in the New Almaden area was derived from a source rock of Late Jurassic age or younger because the oldest known angiosperms are Late Jurassic (Sun and others, 1998). The dominance of $\mathrm{C}_{29}$ steranes and $\mathrm{C}_{29}$ diasteranes, with moderate oleanane, high $\mathrm{C}_{24}$ tetracyclic terpane, and low $\mathrm{C}_{30}$ sterane concentrations, indicates that oil in the New Almaden area was probably derived from predominantly terrestrial (nonmarine) organic matter, with a lesser marine algal component.

\section{Stable-C-Isotopic Composition}

Measurements of stable-C-isotopic composition $\left(\delta^{13} \mathrm{C}\right.$ value) can be used to establish oil-to-oil and oil-to-sourcerock correlations. In northern California, such measurements have been used to infer the age of the source rock from which a given oil was derived (Magoon and others, 1995; Lillis and others, 2001). For example, the $\delta^{13} \mathrm{C}$ value of the saturatedhydrocarbon fraction of oils derived from Miocene source rocks (including the Monterey Formation) typically ranges from about -24 to -21 permil. In contrast, the $\delta^{13} \mathrm{C}$ value of the saturated-hydrocarbon fraction of California oils derived from Eocene source rocks ranges from about -30 to -28 permil, and from Cretaceous source rocks from about -27 to -25 permil (Lillis and others, 2001).

Stable-C-isotopic analyses of whole oils and of saturatedand aromatic-hydrocarbon fractions in oil from the Peck well yielded $\delta^{13} \mathrm{C}$ values of $-23.32,-23.65$, and -23.14 permil, respectively. Corresponding analyses of oil from the New Almaden area yielded $\delta^{13} \mathrm{C}$ values of $-24.70,-26.58$, and -24.34 permil, respectively. On a crossplot of data from many California oils (fig. 12), oil from the Peck well falls within the group derived from Miocene source rocks, whereas oil from the New Almaden area falls within the group believed to be derived from Cretaceous source rocks (Lillis and others, 2001).

We also measured the stable-C-isotopic composition of bitumen extracted from rock samples collected from outcrops of the Miocene Monterey Formation northeast of the San Andreas Fault, in the Los Gatos and Mount Madonna areas (samples R3, R17, fig. 4; table 4). The $\delta^{13} \mathrm{C}$ values of saturated and aromatic hydrocarbons in bitumen extracted from the Los Gatos Creek sample were -24.65 and -23.67 permil, respectively, consistent with a Miocene source rock (fig. 12); corresponding analyses of bitumen extracted from the Mount Madonna sample yielded $\delta^{13} \mathrm{C}$ values of -23.97 and -23.20 permil, respectively, consistent with a Miocene source rock and close to those of oil from the Peck well (fig. 12).

\section{Rock-Eval Pyrolysis}

We used Rock-Eval pyrolysis to investigate the thermal maturity and hydrocarbon-source potential of (1) marine shale and mudstone of the Miocene Monterey Formation and (2) black limestone of the Cretaceous Calera Limestone of the 
Permanente terrane of the Franciscan Complex. Rock samples were collected in the field and crushed to approximately 100mesh particle size. Samples from the Monterey Formation were pyrolyzed by using a Delsi Rock-Eval II instrument equipped with an organic-C module in the USGS laboratories in Denver, Colo., whereas samples of Cretaceous rocks were pyrolyzed by using similar equipment in a commercial laboratory operated by Humble Geochemical Services of Humble, Tex.

The locations of samples are shown in figure 4, and the analytical results are summarized in tables 4 and 5. We caution, however, that our results from the southwestern Santa Clara Valley should be regarded as preliminary because only a few samples were analyzed and interpretation of the data is complicated by the effects of outcrop weathering.

Rock-Eval pyrolysis is a widely used method of rapidly evaluating the quantity, quality, and thermal maturity of prospective petroleum-source rocks (Espitalié and others, 1977, 1984; Clementz and others, 1979; Tissot and Welte, 1984; Peters, 1986). The procedure mimics, in some respects, the natural hydrocarbon-generation processes that occur at much slower rates within the Earth when sedimentary deposits containing kerogen (insoluble sedimentary organic matter) are buried progressively deeper and subjected to increasing temperatures (Waples, 1985). Pulverized samples of rock are held at $250^{\circ} \mathrm{C}$ for 3 minutes (the so-called isothermal period), then heated from 250 to $600^{\circ} \mathrm{C}$ at $25^{\circ} \mathrm{C}$ per minute in an oxygen-free atmosphere, causing water, carbon dioxide, and hydrocarbons to be released from the rock. Several parameters are measured automatically by the Rock-Eval apparatus (tables 4, 5). S1 is the amount of hydrocarbons (HC) (in milligrams per gram of rock) that is released upon initial heating to $250^{\circ} \mathrm{C}$; this parameter includes the amount of bitumen (free organic compounds, including gas and oil) already present in the rock. S2 is the amount of HC (in milligrams per gram of rock) generated by pyrolytic degradation (or "cracking") of the remaining organic matter in the rock; this parameter is an indicator of the potential of the rock to generate additional oil and gas. $T_{\max }$ is the temperature-generally about $400-500^{\circ} \mathrm{C}$ - at which $\mathrm{S} 2$ is a maximum; this parameter is regarded as an approximate indicator of thermal maturity. S3 is the amount of $\mathrm{CO}_{2}$ (in milligrams per gram of rock) generated during pyrolysis; this parameter is believed to be related to the oxygen content of the pyrolyzed organic matter. Calculated Rock-Eval parameters include (1) total organic-carbon (TOC) content (in weight percent); (2) the hydrogen index (HI), defined as the product $100(\mathrm{~S} 2 / \mathrm{TOC})$ and sometimes expressed as milligrams of $\mathrm{HC}$ per gram of organic $\mathrm{C}$; (3) the oxygen index (OI), defined as the product 100(S3/TOC) and sometimes expressed as milligrams of $\mathrm{CO}_{2}$ per gram of organic $\mathrm{C}$; and (4) the production index (PI), defined as the ratio $\mathrm{S} 1 /(\mathrm{S} 1+\mathrm{S} 2)$.

\section{Results from Miocene Rocks}

The organic-matter content of our samples is given by the TOC content and the parameters S1 and S2. Sample R3 (from the Monterey Formation near downtown Los Gatos) contains 3.18 weight percent TOC and has an S2 value of $10.83 \mathrm{mg}$ $\mathrm{HC} / \mathrm{g}$ rock (table 4); comparison of these values with commonly used benchmarks (table 6) suggests that this sample has a very good hydrocarbon-source potential (Peters, 1986). Samples R16 and R17 (from probable Monterey Formation near Mount Madonna; unit Tsh of McLaughlin, 1971) contain 1.61 and 0.81 weight percent TOC and have S2 values of 3.21 and $0.40 \mathrm{mg} \mathrm{HC} / \mathrm{g}$ rock, respectively; these samples appear to have a fair to good hydrocarbon-source potential. Samples R12 through R15 (from the Monterey Formation approx 10 $\mathrm{km}$ southwest of Morgan Hill) have very low TOC contents (0.27-0.49 weight percent), very low S2 values (0.36-0.72 $\mathrm{mg} \mathrm{HC/g}$ rock), and unusually high OI values (151-205 mg
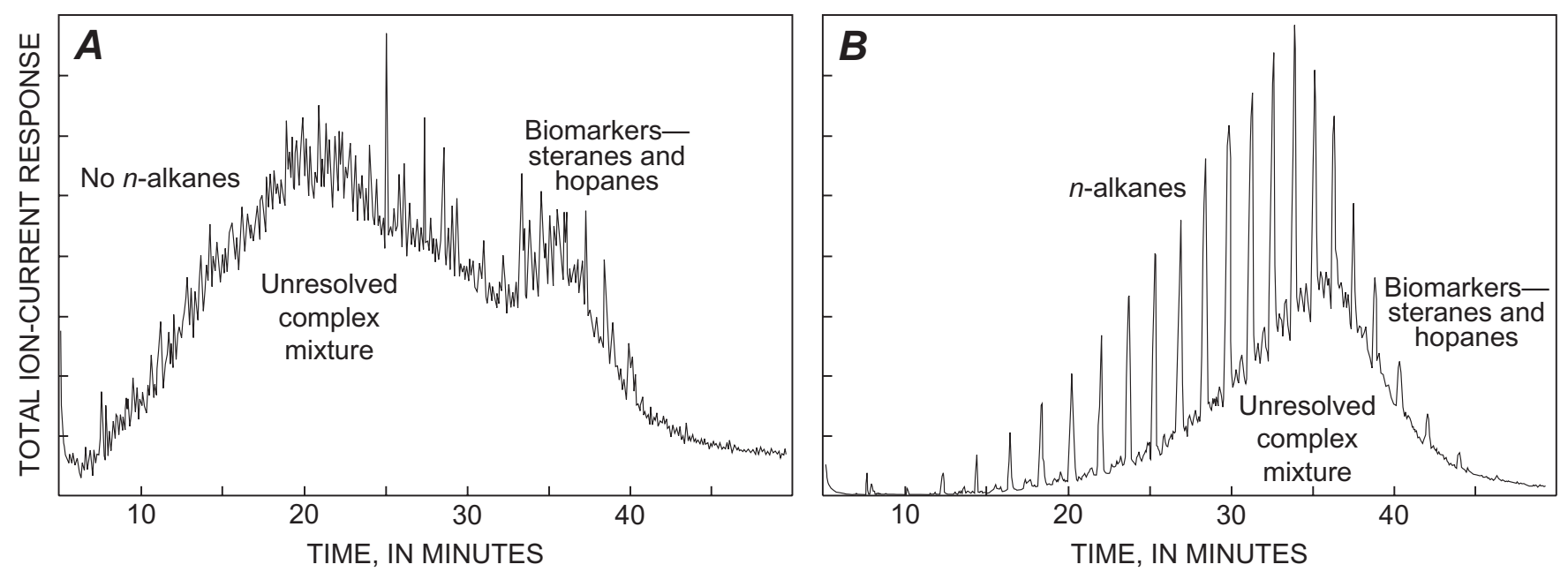

Figure 11.-Mass chromatograms of oil from the Peck well in the Los Gatos area $(A)$ and from the New Almaden area $(B)$ (see fig. 2 for locations). Sample of oil from the New Almaden area was obtained from a vug in mercury ore collected from the informally named Powder House dump, about $2 \mathrm{~km}$ west-northwest of New Almaden, at lat $37.18133^{\circ} \mathrm{N}$. , long $121.84400^{\circ} \mathrm{W}$. 
$\mathrm{CO}_{2} / \mathrm{g}$ organic C) (table 4). We attribute these values to oxidation of organic matter during outcrop weathering because (1) the samples were collected from weathered roadcuts along a ridgetop and (2) previous studies have shown that weathering can cause reduced TOC contents and S2 values and elevated OI values (Leythaeuser, 1973; Clayton and Swetland, 1973; Katz, 1983; Peters, 1986; Stanley, 1987a).

The $S 1$ values of all our samples are very low or zero (table 4), indicating that the samples contain little or no bitumen (free organic compounds, including oil and gas). The most likely reason for these very low S1 values is that the rocks never generated bitumen because they are thermally immature, as discussed below. In addition, very low S1 values suggest that no petroleum has migrated into our samples from other hydrocarbon-source beds. Low S1 values can also be caused by outcrop weathering and by adsorption onto clay minerals of the hydrocarbons produced during pyrolysis (Peters, 1986).

Plots of HI versus OI on a modified van Krevelen diagram (fig. 13) show a range of kerogen compositions. The kerogens in samples R3 and R17 (fig. 4; table 4) are intermediate between types II and III, whereas the kerogens in the rest of the samples appear to be types III and (or) IV. Type II kerogens are commonly regarded as sources of oil and gas, type III kerogens are sources mainly of gas, and type IV kerogens are inert (Peters, 1986; K.E. Peters, written commun., 1992).

A range in kerogen compositions is also suggested by variations in $\mathrm{HI}$ values and $\mathrm{S} 2 / \mathrm{S} 3$ ratios. The kerogen in sample R3 (fig. 4; table 4) has an HI value of $340 \mathrm{mg} \mathrm{HC/g}$ organic $\mathrm{C}$ and an S2/S3 of 5.55; comparison of these values with the benchmarks in table 7 suggests that this sample is "oil prone," or capable of generating oil. The kerogen in sample 17 has an HI value of 199 and an S2/S3 ratio of 4.39, suggesting that it could be a source of both oil and gas. The rest of the samples exhibit generally lower HI values and S2/ S3 ratios; at first glance, these samples appear to be mainly gas prone, but (as noted above) the analytical results from these samples may have been affected by outcrop weathering. Previous studies have shown that HI values and S2/S3 ratios can be reduced by weathering (Peters, 1986; Stanley, 1987a).

All of the Monterey Formation samples analyzed (table 4) exhibit $T_{\max }$ values of $428^{\circ} \mathrm{C}$ or less and PI values of 0.02 or less, indicating that these rocks are thermally immature with respect to the oil-generative window (table 8).

In summary, Rock-Eval pyrolysis results from seven outcrop samples suggest that the Monterey Formation in the southwestern Santa Clara Valley area is a potential source of oil and gas. The seven samples that we analyzed are all thermally immature and probably never generated any hydrocarbons. However, if similar organic-rich strata occur in sufficient volume within the Monterey Formation in the subsurface beneath the southwestern Santa Clara Valley, and if these organic-rich strata were buried as deeply as the oil-generative window, they may have generated significant amounts of hydrocarbons-including the oil and gas found in wells in the Los Gatos area.

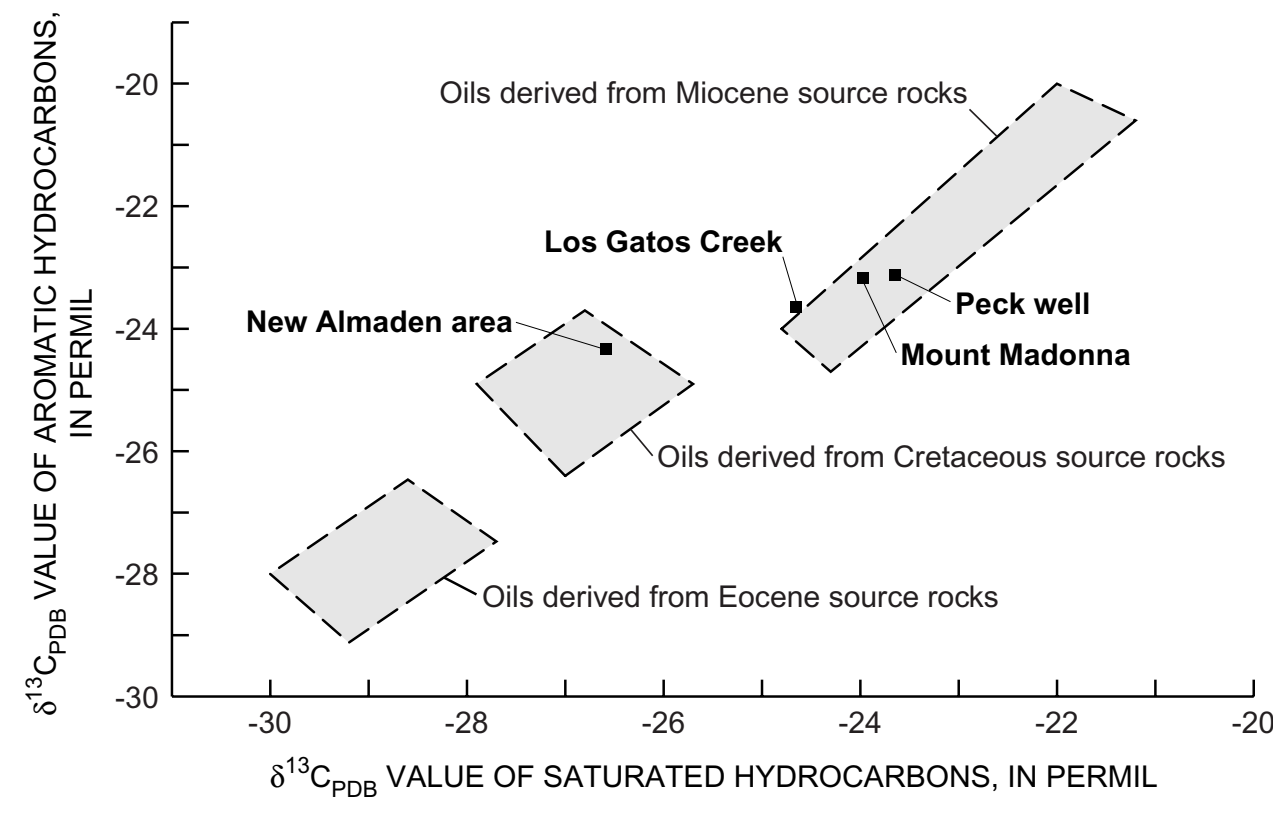

Figure 12.-Stable-C-isotopic compositions of oil and bitumen samples from the southwestern Santa Clara Valley and vicinity, Calif. (fig. 1), shown on crossplot of Lillis and others (2001). Plot suggests that oil from the Peck well and bitumen from Los Gatos Creek and Mount Madonna were derived from Miocene source rocks, whereas oil from the New Almaden area was derived from Cretaceous source rock. 
Table 4.-Rock-Eval pyrolysis data on outcrop samples of Miocene marine shale and mudstone from the southwestern Santa Clara Valley and vicinity, Calif.

[See figures 4 and 5 for sample localities, and appendix for descriptions. HC, hydrocarbons; $\mathrm{HI}$, hydrogen index; $\mathrm{Ol}$, oxygen index; $\mathrm{PI}$, production index; S1, amount of hydrocarbons (in milligrams per gram of rock) released upon initial heating to $250^{\circ} \mathrm{C}$; $\mathrm{S}$, amount of hydrocarbons (in milligrams per gram of rock) generated by pyrolytic degradation ("cracking") of remaining organic matter; $\mathrm{S} 3$, amount of $\mathrm{CO}_{2}$ (in milligrams per gram of rock) generated during pyrolysis; $T_{\max }$ temperature at which $\mathrm{S} 2$ is a maximum; TOC, total organic carbon. Do., ditto]

\begin{tabular}{|c|c|c|c|c|c|c|c|c|c|c|}
\hline Sample & Area & $\begin{array}{c}\text { TOC } \\
\text { content } \\
\text { (weight } \\
\text { percent) }\end{array}$ & $\begin{array}{c}\text { S1 } \\
\text { (mg } \\
\text { HCl } \\
\text { g rock) }\end{array}$ & $\begin{array}{c}\mathrm{S} 2 \\
\mathrm{mg} \mathrm{HC} / \\
\mathrm{g} \text { rock) }\end{array}$ & $\begin{array}{c}\mathrm{S} 3 \\
(\mathrm{mg} \\
\mathrm{CO}_{2} / \\
\text { g rock) }\end{array}$ & $\begin{array}{c}\mathrm{S} 2 / \mathrm{S} 3 \\
\text { ratio }\end{array}$ & HI & OI & PI & $\begin{array}{l}T_{\max } \\
\left({ }^{\circ} \mathrm{C}\right)\end{array}$ \\
\hline R3 & Los Gatos------1-- & 3.18 & 0.00 & 10.83 & 1.95 & 5.55 & 340 & 61 & 0.00 & 406 \\
\hline R12 & SW. of Morgan Hill------- & .51 & .00 & .40 & 1.05 & .38 & 78 & 205 & .00 & 422 \\
\hline R13 & do---1 & .39 & .00 & .63 & .58 & 1.08 & 161 & 148 & .00 & 425 \\
\hline R14 & do----------------------------- & .27 & .00 & .36 & .41 & .87 & 133 & 151 & .00 & 420 \\
\hline R15 & do------------------------------ & .49 & .01 & .72 & .74 & .97 & 146 & 151 & .01 & 423 \\
\hline R16 & NE. of Mount Madonna --- & .81 & .00 & .40 & 1.04 & .38 & 49 & 128 & .00 & 428 \\
\hline R17 & do--------------------- & 1.61 & .08 & 3.21 & .73 & 4.39 & 199 & 45 & .02 & 426 \\
\hline
\end{tabular}

Table 5.-Rock-Eval pyrolysis data on outcrop samples of the Cretaceous Calera Limestone of the Permanente terrane of the Franciscan Complex.

[Samples were collected from fresh excavations at approximately 268-m elevation in the Kaiser Permanente quarry (fig. 2) near Cupertino, Santa Clara County, Calif., in sec 17, T. 7 S., R. 2 W., Cupertino 7.5-minute quadrangle. HC, hydrocarbons; HI, hydrogen index; Ol, oxygen index; PI, production index; S1, amount of hydrocarbons (in milligrams per gram of rock) released upon initial heating to $250^{\circ} \mathrm{C} ; \mathrm{S} 2$, amount of hydrocarbons (in milligrams per gram of rock) generated by pyrolytic degradation ("cracking") of remaining organic matter; $\mathrm{S} 3$, amount of $\mathrm{CO}_{2}$ (in milligrams per gram of rock) generated during pyrolysis; $T_{\max }$, temperature at which S2 is a maximum; TOC, total organic carbon. Do., ditto]

\begin{tabular}{|c|c|c|c|c|c|c|c|c|c|c|}
\hline Sample & $\begin{array}{l}\text { Latitude, } \\
\text { longitude }\end{array}$ & $\begin{array}{l}\text { TOC } \\
\text { content } \\
\text { (weight } \\
\text { percent) }\end{array}$ & $\begin{array}{c}\mathrm{S} 1 \\
(\mathrm{mg} \\
\mathrm{HCl} \\
\mathrm{g} \text { rock) }\end{array}$ & $\begin{array}{c}\mathrm{S} 2 \\
(\mathrm{mg} \\
\mathrm{HCl} \\
\text { g rock) }\end{array}$ & $\begin{array}{c}\mathrm{S} 3 \\
(\mathrm{mg} \\
\mathrm{CO}_{2} / \\
\text { g rock) }\end{array}$ & $\begin{array}{l}\mathrm{S} 2 / \mathrm{S} 3 \\
\text { ratio }\end{array}$ & HI & OI & PI & $\begin{array}{l}T_{\max } \\
\left({ }^{\circ} \mathrm{C}\right)\end{array}$ \\
\hline $\mathrm{KP}-1$ & $\begin{array}{l}37.32217^{\circ} \mathrm{N} . \\
122.10817^{\circ} \mathrm{W} .\end{array}$ & 4.63 & 0.10 & 1.18 & 0.22 & 5.36 & 25 & 5 & 0.08 & 569 \\
\hline $\mathrm{KP}-2$ & $\begin{array}{l}37.32217^{\circ} \mathrm{N} . \\
122.10800^{\circ} \mathrm{W}\end{array}$ & 4.37 & .09 & 1.09 & .14 & 7.79 & 25 & 3 & .08 & 557 \\
\hline $\mathrm{KP}-3$ & $\begin{array}{l}37.32200^{\circ} \mathrm{N} . \\
122.10800^{\circ} \mathrm{W} .\end{array}$ & 4.16 & .16 & 1.09 & .13 & 8.38 & 26 & 3 & .13 & 558 \\
\hline $\mathrm{KP}-4$ & $\begin{array}{l}37.32167^{\circ} \mathrm{N} . \\
122.10800^{\circ} \mathrm{W} .\end{array}$ & 3.59 & .02 & .92 & .15 & 6.13 & 26 & 4 & .02 & 567 \\
\hline $\mathrm{KP}-5$ & $\begin{array}{l}37.32183^{\circ} \mathrm{N} ., \\
122.10800^{\circ} \mathrm{W} .\end{array}$ & 4.01 & .02 & 1.04 & .16 & 6.50 & 26 & 4 & .02 & 568 \\
\hline KP-6 & $\begin{array}{l}37.32150^{\circ} \mathrm{N} . \\
122.10800^{\circ} \mathrm{W}\end{array}$ & 4.12 & .08 & .98 & .15 & 6.53 & 24 & 4 & .08 & 555 \\
\hline
\end{tabular}

\section{Possible Sources of Oil in the New Almaden Area}

The source rock of oil in the New Almaden area is unidentified and enigmatic. As noted above, however, the stable-Cisotopic values indicate a source of Cretaceous age, consistent with the biomarker data that indicate a source of Late Jurassic age or younger. The biomarker data also suggest predominantly terrestrial (nonmarine) organic-matter-source facies.

In the southwestern Santa Clara Valley, source-rock candidates of Cretaceous age include dark-gray to black marine limestone within the Calera Limestone of the Permanente terrane of the Franciscan Complex. Evidence from foraminiferal assemblages and radiolarian faunas (summarized by McLaughlin and others, 1996a) indicates that the Calera Limestone ranges in age from Early Cretaceous (Hauterivian or Barremian to early Aptian) to Late Cretaceous (Turonian). The dark limestone within the Calera Limestone is presumably of Barremian or Aptian age and is thought to have been deposited under anoxic conditions that favored the preservation of organic matter (Sliter and others, 1991; Sliter and McGann, 1992). We tested the hydrocarbon-source potential of these rocks by using Rock-Eval pyrolysis of six rock samples collected from fresh excavations in the active Kaiser Cement Corp.'s Permanente Quarry near Cupertino (fig. 2; table 5). The $T_{\max }$ values obtained from these samples $\left(555-569^{\circ} \mathrm{C}\right)$ are much greater than the value of about $470^{\circ} \mathrm{C}$ that marks the base of the oil-generative window (table 8), indicating that these samples have reached a high level of thermal maturity. TOC contents in these samples are high, 
Table 6.-Rock-Eval parameters describing petroleum-generative potential.

[Data from Peters (1986). HC, hydrocarbons; S1, amount of hydrocarbons (in milligrams per gram of rock) released upon initial heating to $250^{\circ} \mathrm{C}$; $\mathrm{S} 2$, amount of hydrocarbons (in milligrams per gram of rock) generated by pyrolytic degradation ("cracking") of remaining organic matter; TOC, total organic carbon]

\begin{tabular}{cccc}
\hline Potential & $\begin{array}{c}\text { TOC content } \\
\text { (weight percent) }\end{array}$ & $\begin{array}{c}\mathrm{S} 1 \\
(\mathrm{mg} \mathrm{HC} / \mathrm{g} \text { rock) }\end{array}$ & $\begin{array}{c}\mathrm{S} 2 \\
\text { (mg HC/g rock) }\end{array}$ \\
\hline & & & \\
Poor---------- & $0-0.5$ & $0-0.5$ & $0-2.5$ \\
Fair ---------- & $.5-1.0$ & $.5-1.0$ & $2.5-5.0$ \\
Good---------- & $1.0-2.0$ & $1.0-2.0$ & $5.0-10.0$ \\
Very good---- & $2.0+$ & $2.0+$ & $10.0+$ \\
\hline
\end{tabular}

ranging from 3.59 to 4.63 weight percent (table 5), but S2 values are very low $(0.92-1.18 \mathrm{mg} \mathrm{HC} / \mathrm{g}$ rock), suggesting that the organic carbon in these rocks has little or no remaining potential to generate hydrocarbons. The high thermal maturity of these samples may also explain the very low $\mathrm{S} 1$ values $(0.02-0.16 \mathrm{mg} \mathrm{HC} / \mathrm{g}$ rock), which indicate that the samples contain little or no bitumen, as well as the very low HI values (24-26). TOC contents as high as 5.7 weight percent were previously reported for these rocks by Larue (1986, 1991), who noted that the organic matter in the dark limestone appeared to be thermally degraded and that little could be learned about its composition and origin. We conclude that these rocks may have generated hydrocarbons in the past but have no remaining potential to generate oil.

The Rock-Eval pyrolysis results are consistent with the hypothesis that strata correlative with the Cretaceous Calera Limestone may have been the source rocks of the oil that is

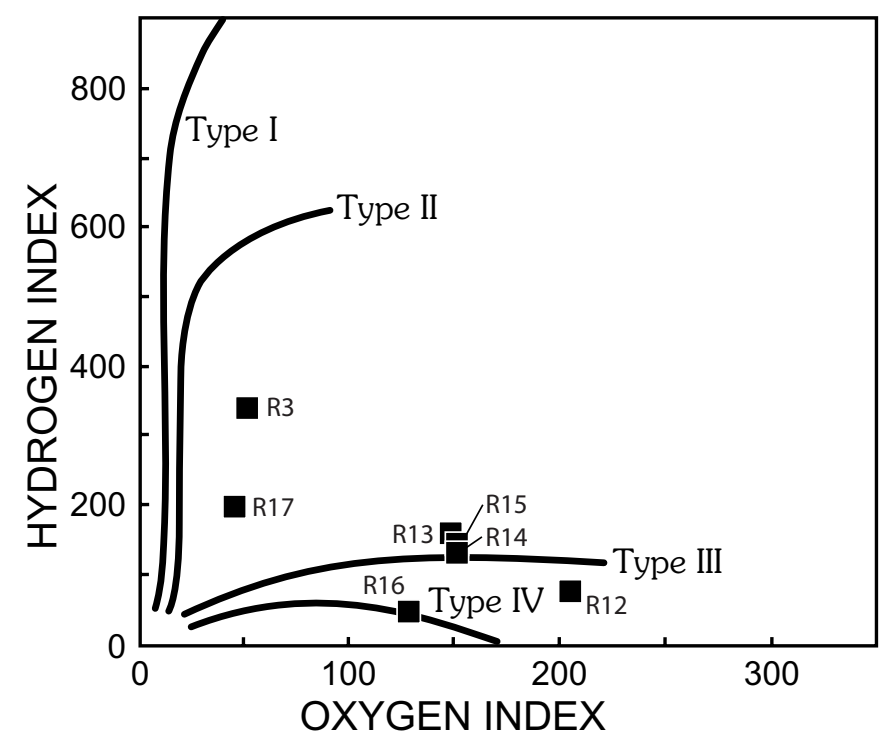

Figure 13.--Modified van Krevelen diagram (Peters, 1986) showing idealized kerogen types (solid lines) and results for samples of Miocene marine shale and mudstone from the southwestern Santa Clara Valley and vicinity, Calif. (squares) (see fig. 4 and appendix for sample locations). Types I and II kerogens are oil prone, type III kerogens are gas prone, and type IV kerogens are inert (Peters, 1986). associated with mercury ore in the New Almaden area. Such limestone is known to be present in the New Almaden area from surface mapping (McLaughlin and others, 2001) and from subsurface occurrences in mine shafts (for example, Bailey and Everhart, 1964, pl. 14). Other source-rock candidates of Cretaceous age may exist in strata correlative with Cretaceous outcrops in the Santa Teresa Hills and the southeastern Santa Cruz Mountains (fig. 2; see McLaughlin and others, 2001), but no Rock-Eval pyrolysis results or other organic-geochemical information is presently available from these strata.

\section{Depth to the Top of the Oil-Generative Window in the Southwestern Santa Clara Valley}

Although the depth from the surface to the top of the oilgenerative window (the range of depths within which oil is generated from source rocks) in the southwestern Santa Clara Valley is unknown, the following three lines of reasoning suggest that it may presently be at about 2,100- to 2,500-m depth. 1 . The depth to the top of the oil-generative window can be estimated by comparing the temperature at which oil generation typically begins with subsurface temperatures in the Los Gatos area. We assume that oil generation begins at a temperature of about $93^{\circ} \mathrm{C}$, approximately equivalent to a Rock-Eval $T_{\max }$ value of about $435-445^{\circ} \mathrm{C}$ and an $R_{0}$ value of 0.6 percent (table 8). We believe that this temperature is a reasonable estimate for the onset of oil generation in most sedimentary basins, including the Santa Clara Valley, but we recognize that oil may be generated at lower temperatures from certain types of high-sulfur kerogen in the Monterey Formation in some southern California sedimentary basins, as noted by Baskin and Peters (1992). Estimates of subsurface temperatures in the Los Gatos area (table 9), based on analogy with temperature and heat-flow measurements from wells in other parts of the San Francisco Bay region, were provided by Colin Williams (written commun., 1996). The data listed in table 9 indicate that the present-day top of the oil-generative window is probably at about 2,100-m depth. If uncertainties in the estimated subsurface temperatures are taken into account, the top of the oil-generative window could be as shallow as $1,800 \mathrm{~m}$ or as deep as $2,500 \mathrm{~m}$.

2. The depth to the top of the oil-generative window can be approximated by analogy with other, geologically similar sedimentary basins in California in which moderately mature, low-sulfur oils were derived from source rocks of Miocene age. However, only a few estimates of the depth to the top of the oil-generative window in such basins have been published. The present-day top of the oil-generative window is at about 1,600- to 2,000-m depth in the Pismo Basin (Heasler and Surdam, 1983), at about 2,300- to 2,500-m depth in the Los Angeles Basin (Thane McCulloh, oral commun., 1996), and at about 2,500-m depth in the Cuyama Basin (Lillis, 1994).

3. As noted above, evidence from biomarkers suggests that oil in the Peck well was generated from Miocene source rocks that were buried to at least 2,100-m depth. The top of 
Table 7.- Rock-Eval parameters describing types of hydrocarbon generated.

[Data from Peters (1986). HI, hydrogen index; S2, amount of hydrocarbons (in milligrams per gram of rock) generated by pyrolytic degradation ("cracking") of remaining organic matter; $\mathrm{S} 3$, amount of $\mathrm{CO}_{2}$ (in milligrams per gram of rock) generated during pyrolysis]

\begin{tabular}{ccc}
\hline Type & HI & S2/S3 ratio \\
& & \\
\hline Gas---------- & $0-150$ & $0-3$ \\
Gas and oil---- & $150-300$ & $3-5$ \\
Oil -------- & $300+$ & $5+$ \\
& & \\
\hline
\end{tabular}

the oil-generative window in the southwestern Santa Clara Valley must have been at similar depths when this oil was generated, if geothermal gradients in the past were about the same as at present.

Taken together, these three lines of reasoning suggest that the present-day top of the oil-generative window in the southwestern Santa Clara Valley is probably at about 2,100to 2,500-m depth, but could be as shallow as about 1,600- to 1,800 -m depth. Thus, if suitable hydrocarbon-source rocks are presently buried as deep as, or deeper than, 2,100- to 2,500-m depth (as we believe likely), then oil generation may be occurring now. In the geologic past, the geothermal gradient in the southwestern Santa Clara Valley may have differed from the present gradient, and the depth to the top of the oil-generative window may have been deeper or shallower than at present. The modern geothermal gradient implied by the estimated subsurface temperatures listed in table 9 is about $37^{\circ} \mathrm{C} / \mathrm{km}$, but uncertainties in these estimates imply that the modern geothermal gradient could be as low as 31 or as high as $43^{\circ} \mathrm{C} / \mathrm{km}$.

\section{Implications for Structure and Tectonics}

Two of many possible alternative interpretations of the geologic structure along the southwestern margin of the Santa Clara Valley are shown in the cross sections in figure 14. Both cross sections are consistent with the geologic, geophysical, and organic-geochemical evidence discussed above, and both were drawn along a northeast-trending line that passes through the Blossom Hill area about $3 \mathrm{~km}$ east of the Los Gatos Post Office (fig. 5). As discussed below, however, the two cross sections imply different interpretations of the tectonic evolution of the southwestern Santa Clara Valley.

In both cross sections (fig. 14), high-density Franciscan Complex rocks northeast of the Monte Vista Fault are overlain by about $2.5 \mathrm{~km}$ of low-density rocks. The stratigraphy of the upper part of the low-density interval is constrained by Traders Oil Corp. Well No. 2, which drilled through about $124 \mathrm{~m}$ of material that we interpret as Santa Clara Formation and (or) younger Quaternary deposits, and about $691 \mathrm{~m}$ of Miocene Monterey Formation. The stratigraphy of the low-density interval below the total depth of this well, about $815 \mathrm{~m}$, is uncertain.
Table 8.-Organic-geochemical parameters describing level of thermal maturation.

[All values approximate. Data from Peters (1986). PI, production index; $R_{0}$, vitrinite reflectance; S1, amount of hydrocarbons (in milligrams per gram of rock) released upon initia heating to $250^{\circ} \mathrm{C} ; \mathrm{S} 2$, amount of hydrocarbons (in milligrams per gram of rock) generated by pyrolytic degradation ("cracking") of remaining organic matter; $T_{\text {burial }}$ estimated burial temperature, calculated by using equation $\ln R_{0}=0.0096 T_{\text {burial }}-1.4$ (Barker, 1988); $T_{\max }$, temperature at which $\mathrm{S} 2$ is a maximum. Both $\mathrm{Pl}$ and $T_{\text {mx }}$ are crude measurements of thermal maturation that partly depend on other factors, including type of organic matter (Peters, 1986)]

\begin{tabular}{ccccc}
\hline Maturation & $\begin{array}{c}\text { PI } \\
{[\mathrm{S} 1 /(\mathrm{S} 1+\mathrm{S} 2)]}\end{array}$ & $\begin{array}{c}T_{\max } \\
\left({ }^{\circ} \mathrm{C}\right)\end{array}$ & $\begin{array}{c}R_{0} \\
(\text { percent })\end{array}$ & $\begin{array}{c}T_{\text {burial }} \\
\left({ }^{\circ} \mathrm{C}\right)\end{array}$ \\
\hline $\begin{array}{l}\text { Top of oil-generative window ------ } \\
\text { Bottom of oil-generative window --- }\end{array}$ & $\begin{array}{l}\text { ca. } 0.1 \\
\text { ca. } 0.4\end{array}$ & $\begin{array}{c}\text { ca. } 435-445 \\
\text { ca. } 470\end{array}$ & $\begin{array}{l}\text { ca. } 0.6 \\
\text { ca. } 1.4\end{array}$ & $\begin{array}{r}\text { ca. } 93 \\
\text { ca. } 181\end{array}$ \\
\hline
\end{tabular}

In this area, the Franciscan Complex may be directly overlain by Miocene strata, as shown in figure 14; alternatively, the Franciscan may be overlain by Upper Cretaceous to Eocene rocks resembling those found in outcrop in the Santa Teresa Hills, Palo Alto, and Mount Umunhum areas (approx $5 \mathrm{~km}$ east, $30 \mathrm{~km}$ northwest, and $10 \mathrm{~km}$ south, respectively, of the line of our cross section; see fig. 2). We prefer the first interpretation for the following reasons: (1) Available surface geologic

\begin{tabular}{|c|c|}
\hline $\begin{array}{l}\text { Depth } \\
\text { (m) }\end{array}$ & $\begin{array}{c}\text { Temperature } \\
\left({ }^{\circ} \mathrm{C}\right)\end{array}$ \\
\hline 100 & 18.0 \\
\hline 300 & $25.5 \pm 1.2$ \\
\hline 500 & $33.0 \pm 2.4$ \\
\hline 700 & $40.4 \pm 3.6$ \\
\hline 900 & $47.9 \pm 4.8$ \\
\hline 1,100 & $55.4 \pm 6.0$ \\
\hline 1,300 & $62.9 \pm 7.2$ \\
\hline 1,500 & $70.4 \pm 8.4$ \\
\hline 1,700 & $77.8 \pm 9.6$ \\
\hline 1,900 & $85.3 \pm 10.8$ \\
\hline 2,100 & $92.8 \pm 12.0$ \\
\hline 2,300 & $100.3 \pm 13.2$ \\
\hline 2,500 & $107.8 \pm 14.4$ \\
\hline
\end{tabular}

mapping indicates that strata of Late Cretaceous to Eocene age are absent along the line of our cross section and that Miocene strata in several places rest directly (in inferred depositional contact) on the Franciscan Complex (Bailey and Everhart, 1964; McLaughlin and others, 1991a, b, 2001); and (2) organicgeochemical evidence, as discussed above, suggests that oil in the Peck well in Los Gatos was generated from a source rock in the Miocene Monterey Formation at about 2,100-m depth or more. We infer that this oil was derived from thermally mature, deeply buried Monterey Formation source rocks within the concealed sedimentary basin immediately northeast of the Monte Vista Fault (fig. 14). If this inference and the organic-geochemi- 
cal interpretations are correct, then oil-generating source rocks of the Monterey Formation northeast of the Monte Vista Fault must be deeper than about 2,100 m.

Thus, integration of geologic, geophysical, and organicgeochemical data suggests that Miocene strata in the concealed, subsurface sedimentary basin northeast of the Monte Vista Fault extend to greater than 2,100-m depth (the shallowest depth allowed by organic-geochemical evidence), possibly to about 4,000-m depth (as suggested by gravity modeling). These estimates, in turn, imply that Miocene strata in the subsurface along the line of our cross sections are about 2,000 to 3,000 m
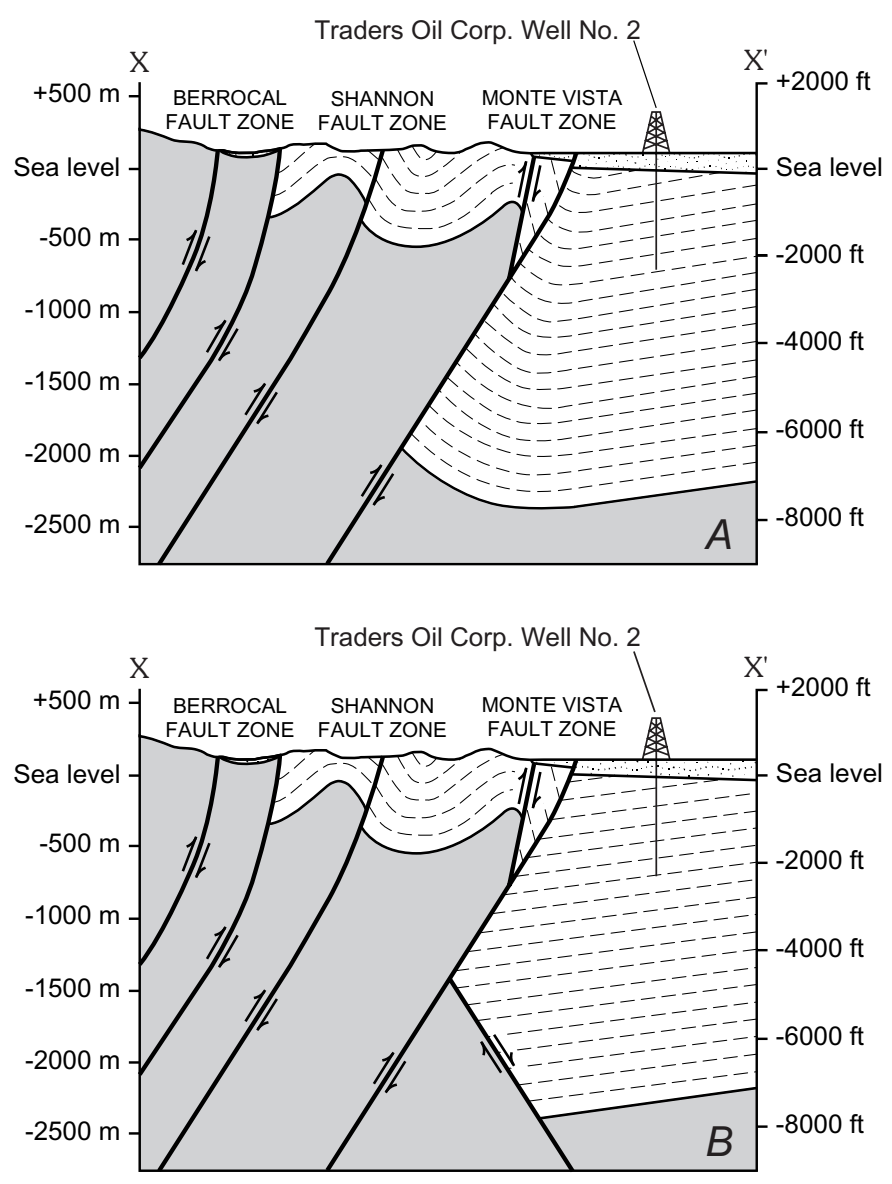

EXPLANATION

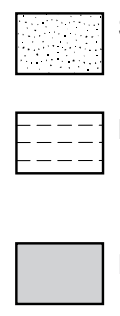

Santa Clara Formation and (or) younger nonmarine deposits (Quaternary and Pliocene)

Miocene marine sedimentary rocks and minor volcanic rocks (including the Temblor and Monterey Formations of Bailey and Everhart, 1964)

Franciscan Complex, Coast Range ophiolite, and serpentinite, undivided (Cretaceous and Jurassic)

Figure 14.- Schematic diagrams showing two possible structural interpretations in the Los Gatos area, Calif. (see fig. 5 for line of cross section). A, Faulted-syncline interpretation. B, Overthrust-normalfault interpretation. Traders Oil Co. Well No. 2 (total depth, 2,675 ft) is projected from about $1.7 \mathrm{~km}$ to northwest. thick, considerably more than the thicknesses of 640 to 1,160 $\mathrm{m}$ observed in nearby Miocene outcrops (Bailey and Everhart, 1964, p. 71; McLaughlin and others, 1991a, p. 12). In the following subsections, we propose some possible solutions to this apparent discrepancy.

\section{Faulted-Syncline Interpretation}

Our first structural interpretation (fig. 14A) hypothesizes that Miocene strata about $2.5 \mathrm{~km}$ thick are gently folded into a broad syncline which is bounded on the southwest by the southwest-dipping hanging wall of the Monte Vista Fault zone. The thickest part of the concealed Miocene sedimentary basin is overthrust by rocks of the Franciscan Complex along the fault zone. Southwest of the Monte Vista Fault zone, Miocene strata are apparently thinner, are cut by southwest-dipping thrust faults (including the Berrocal and Shannon Fault zones), and are involved in tight and locally overturned folds.

On both sides of the Monte Vista Fault zone, Miocene strata are overlain in angular unconformity by the late Pliocene and Pleistocene Santa Clara Formation and (or) younger Quaternary nonmarine deposits. The thickness of missing Miocene strata represented by this angular unconformity is unknown and may vary from place to place. Before reverse slip occurred along the Monte Vista Fault, the original thickness of Miocene deposits on both sides of the fault may have been at least 2.5 $\mathrm{km}$. Post-Miocene reverse slip along the Berrocal, Shannon, and Monte Vista Faults may have been accompanied by folding, uplift, and probable deep erosion of Miocene (and overlying) strata on the upthrown (southwest) side of the Monte Vista Fault, whereas Miocene strata on the downthrown (northeast) side of the fault may have been deformed, uplifted, and eroded much less.

An alternative explanation of the cross section in figure $14 A$ is that the Monte Vista Fault has undergone many kilometers of right slip in addition to some reverse slip and that at least some of the folding in the southwestern Santa Clara Valley and adjacent Santa Cruz Mountains is related to wrench tectonism. The amount of right-lateral displacement along faults of the range-front fault system is unknown but could be large (Hay and others, 1980; McLaughlin and others, 1996b, 2001). The relatively thin sequence of Miocene rocks on the southwest side of the Monte Vista Fault may have been deposited many kilometers away, and in a different sedimentary basin, from the much thicker Miocene sequence on the northeast side of the fault, and then these two Miocene basins may have subsequently been juxtaposed by post-Miocene right slip along the fault. This interpretation could be tested by comparative stratigraphic and sedimentologic studies of Miocene and other rocks on both sides of the Monte Vista Fault.

\section{Overthrust-Normal-Fault Interpretation}

Our second, preferred structural interpretation (fig. 14B) proposes that a late Cenozoic fold-and-thrust belt (including the northeastward-vergent Berrocal, Shannon, and Monte 
Vista Faults and related folds) formed in approximately the same position as an older system of Miocene down-to-thenortheast normal faults. Our cross section was inspired by a general model proposed by Davis and others (1996, p. 191) for the evolution of Miocene sedimentary basins in southern California.

In this structural interpretation (fig. 14B), Miocene strata about $2.5 \mathrm{~km}$ thick were deposited on the downthrown side of an unnamed, northeast-dipping normal fault with about 2.5 $\mathrm{km}$ of down-to-the-northeast normal slip. Subsequently, the normal fault and part of the Miocene sedimentary basin were truncated and overridden by late Cenozoic reverse slip along the younger, southwest-dipping Monte Vista Fault, which placed Franciscan rocks above the thickest part of the Miocene sedimentary basin and a remnant of the original normal fault. A short, steep, southwest-dipping fault in the hanging-wall block just southwest of the main trace of the Monte Vista Fault may represent a displaced segment of the original Miocene normal fault that, during late Cenozoic compression, was rotated about a horizontal axis from its original northeast-dipping orientation and reactivated as a reverse fault. The much-greater apparent thickness of Miocene strata on the northeast side of the Monte Vista Fault is inferred to have resulted from (1) deposition during the Miocene of a thicker section on the northeast, downthrown side of a hypothetical normal fault that was subsequently overthrust by the Monte Vista Fault; and (2) deeper erosion of Miocene and younger deposits on the hanging-wall block of the Monte Vista Fault during late Cenozoic compression, deformation, and uplift.

The hypothesized normal faults, in turn, imply that the southwestern Santa Clara Valley was affected by an episode of Miocene crustal extension. Although the exact timing of this crustal extension is poorly constrained, we suggest that it may have coincided with accumulation of the Temblor and Monterey Formations, which, as mentioned above, have yielded fossil assemblages of early and middle Miocene age. No biostratigraphic data are available, however, from any Miocene rocks in the subsurface in this area. Miocene normal faulting in the Los Gatos area may have been genetically related to postulated Miocene normal faulting in the Palo Alto area (Angell and Crampton, 1996) and to eruption of 15.6-Ma dacitic volcanic rocks in the Los Gatos area and 14- to 15-Ma basaltic volcanic rocks in Palo Alto (fig. 3). The underlying tectonic cause of Miocene crustal extension in the southwestern Santa Clara Valley is uncertain, but it may have been related to passage of the northwestwardly migrating Mendocino triple junction (McLaughlin and others, 1997a, 2001).

Also unclear are the original shape and lateral extent of the Miocene sedimentary basin. Little is known about the present-day distribution of Miocene rocks beneath the Santa Clara Valley, and virtually nothing about the Miocene paleogeography of the study area (fig. 1). On the basis of gravity evidence suggesting a steep southwestern basin margin and a gently sloping northeastern margin (figs. 6, 7), we infer that Miocene strata beneath the Santa Clara Valley were deposited in a half-graben that was controlled on its southwest flank by one or more northeast-dipping normal faults.

\section{Other Possible Structural Interpretations}

The simple models in figure 14 are based on limited geologic, geophysical, and organic-geochemical data and should therefore be regarded as testable hypotheses subject to revision or rejection as more data are obtained. The geologic structure of the southwestern Santa Clara Valley is probably much more complex than shown in our cross sections and may include buried thrust and reverse faults (also known as "blind thrusts") capable of causing damaging earthquakes. Some intriguing geologic and geophysical evidence suggests that buried thrust and reverse faults are present in the so-called Saratoga embayment northwest of Los Gatos (Hitchcock and others, 1994; Cotton and others, 1994; Langenheim and others, 1997) and beneath Palo Alto (Angell and Crampton, 1996). Additional evidence suggests that the area between the Santa Clara Valley and the San Andreas Fault, from Cupertino to Gilroy, may be underlain by a buried system of active thrust faults (McLaughlin and others, 1997b, 1999).

Further resolution of the subsurface geology of the Santa Clara Valley will require additional geologic and geophysical research. The presence of buried faults might be indicated, for example, by subtle geologic and geomorphologic evidence for folding of late Pleistocene or Holocene deposits (Hitchcock and others, 1994; Jayko, 1996; McLaughlin and others, 1999). A seismic-reflection traverse oriented perpendicular to the northwest-trending structural grain in the Los Gatos area-for example, along or parallel to Los Gatos Boulevard or California Highway 17, from near the Los Gatos Post Office (fig. 5) to a point several kilometers to the northeast in the Santa Clara Valley-might image the Monte Vista Fault zone and any potentially seismogenic blind thrusts or related folds in that area. A proposed project known as USArray (Levander and others, 1999) may provide high-resolution, three-dimensional seismic images that would reveal buried faults and other hidden geologic structures. A deep stratigraphic test well in the thickest part of the concealed Miocene sedimentary basin would provide important geologic constraints on seismic interpretation and modeling of gravity and aeromagnetic data and help to resolve questions regarding the age, tectonic significance, and petroleum-resource potential of this basin.

\section{Implications for Petroleum Resources}

\section{Evidence for a Petroleum-Bearing Sedimentary Basin Beneath the Southwestern Santa Clara Valley}

Abundant geologic, geophysical, and organic-geochemical evidence indicates that a concealed petroleum-bearing Miocene sedimentary basin exists beneath the southwestern Santa Clara Valley (fig. 1). As noted above, several exploratory wells in the Los Gatos area penetrated Miocene and 
younger strata and reported oil and gas shows. A conspicuous, northwest-trending isostatic gravity low that extends from Los Gatos to Palo Alto may reflect northwestward continuation of the Miocene and younger rocks penetrated in the Los Gatos wells (figs. 6, 7); however, the full geographic extent of oil-bearing rocks is unknown because few wells have been drilled outside the Los Gatos area.

Organic-geochemical evidence is consistent with the hypothesis that oil in the Los Gatos wells was derived from hydrocarbon-source rocks within the Miocene Monterey Formation and that these rocks are thermally mature at depths equal to or greater than about 2,100 to 2,500 m. The exact location of the source of the Los Gatos oils is uncertain, but it may have been an area along the Monte Vista Fault where Cenozoic deposits (including the Monterey Formation) are at least 3,000 m thick (fig. 7). Within this area, the potential exists for burial of a substantial thickness of Miocene Monterey Formation hydrocarbon-source rocks that are thermally mature with respect to oil generation; oil derived from these source rocks may have migrated updip to reservoirs that were penetrated by the Peck well and other wells in the Los Gatos area (fig. 5). We are puzzled, however, by the fact that no oil or gas shows or seeps have been reported from the area northwest of Los Gatos. The absence of oil and gas shows in this area may simply reflect the absence of deep wells that penetrate the Monterey Formation, and the absence of seeps may reflect the presence in the subsurface of highly efficient hydrocarbon traps and seals that prevent hydrocarbons from migrating to the surface. Alternatively, the absence of oil and gas shows may be due to an insufficiency of organic-rich source rocks within the Monterey Formation, possibly owing to a lateral change in sedimentary facies. Such a change would be consistent with the observation by Dibblee (1966b) that outcrops of the Monterey Formation become coarser grained to the northwest, from mostly siliceous shale and siltstone south of Los Altos to more sandy strata near Palo Alto.

Oil is unlikely to have been generated from areas where Cenozoic deposits are less than about 2,000 m thick (fig. 7) because, as discussed above, a minimum burial depth of about 2,100 $\mathrm{m}$ seems to be required for thermal maturation of hydrocarbon-source rocks in the Monterey Formation in the southwestern Santa Clara Valley. The absence of oil shows in NASA Ames Research Center Well No. 1 and the USGS coreholes (fig. 2; table 1) may reflect the absence, in the vicinities of those wells, of Monterey Formation source rocks that are of sufficient thickness, organic richness, and (or) thermal maturity to generate petroleum.

\section{Estimate of the Volume of Oil Generated Beneath the Southwestern Santa Clara Valley}

Preliminary estimates of the amount of oil generated from mature source rocks of the Monterey Formation beneath the southwestern Santa Clara Valley can be calculated by using the equations of Schmoker (1994) and several assumptions of questionable validity.
The mass of organic carbon, $M$ (in grams), in the Monterey Formation in the subsurface of the southwestern Santa Clara Valley can be calculated from equation 1 of Schmoker (1994):

$$
M=\frac{1}{100} T_{\text {avg }} r V
$$

where $T_{\text {avg }}$ is the average TOC content (in weight percent) of the source rock, $r$ is the average formation density (in grams per cubic centimeter), and $V$ is the volume (in cubic centimeters) of the source rock.

No data are available on the TOC content of source rocks beneath the southwestern Santa Clara Valley. For our calculations, we assume a TOC content of about 3.5 weight percent on the basis of an optimistic view of our Rock-Eval data. We assume an average formation density of $2.3 \mathrm{~g} / \mathrm{cm}^{3}$ on the basis of borehole gravity measurements near the bottom of NASA Ames Research Center Well No. 1 (Beyer, 1980, p. 48-50) and measurements by V.E. Langenheim (U.S. Geological Survey, written commun., 1997) on outcrop samples collected by R.G. Stanley and R.J. McLaughlin from the Monterey Formation in Los Gatos and other areas northeast of the San Andreas Fault in the Santa Cruz Mountains (figs. 1, 2).

The subsurface thickness and extent of the Monterey Formation beneath the southwestern Santa Clara Valley, and the relative abundance of petroleum-source rocks within the Monterey Formation, are poorly known. For our calculations, we assume that the top of the oil window in the southwestern Santa Clara Valley is at about 2,100-m depth, as discussed above, and that the principal area of oil generation from the Monterey Formation in the southwestern Santa Clara Valley approximately coincides with the area in which low-density Cenozoic deposits are at least $3 \mathrm{~km}$ thick (fig. 7). We model the part of the Monterey Formation that includes thermally mature, potential petroleum-source rocks as a rectangular prism, about $1 \mathrm{~km}$ thick, $15 \mathrm{~km}$ long, and $4 \mathrm{~km}$ wide, with a volume of $60 \mathrm{~km}^{3}$. We further make the conservative assumption, for this calculation, that 10 percent of the Monterey Formation within this prism consists of effective petroleum-source rocks - that is, rocks that are generating or have generated and expelled petroleum.

Equation 1 can then be applied to the southwestern Santa Clara Valley:

$$
\begin{aligned}
M & =(3.5 \text { weight percent } / 100) \times\left(2.3 \mathrm{~g} / \mathrm{cm}^{3}\right) \times\left(6.0 \times 10^{15} \mathrm{~cm}^{3}\right) \\
& =4.83 \times 10^{14} \mathrm{~g} .
\end{aligned}
$$

The mass of hydrocarbons generated per unit mass of organic carbon, $R$ (in milligrams of HC per gram of TOC), is calculated from equation 2 of Schmoker (1994):

$$
R=\mathrm{HI}_{\mathrm{o}}-\mathrm{HI}_{\mathrm{p}},
$$

where $\mathrm{HI}_{\mathrm{o}}$ is the original hydrogen index (in milligrams of HC per gram of TOC) of the source rock before any petro- 
leum generation, and $\mathrm{HI}_{\mathrm{p}}$ is the present-day hydrogen index. $\mathrm{HI}_{\mathrm{p}}$ generally is derived from Rock-Eval pyrolysis of source rocks that have already generated hydrocarbons, whereas $\mathrm{HI}_{\mathrm{o}}$ is derived from Rock-Eval pyrolysis of thermally immature samples. No Rock-Eval data on mature source rocks are available for the Monterey Formation of the southwestern Santa Clara Valley area, and Rock-Eval data on immature samples are very limited. We therefore assume an $R$ value of $200 \mathrm{mg} \mathrm{HC} / \mathrm{g}$ TOC, as used by Bird (1994, p. 354) in similar calculations for the North Slope of Alaska.

The total mass of hydrocarbons generated, HCG (in kilograms of $\mathrm{HC}$ ), is calculated by multiplying the results of the previous two steps and converting from milligrams to kilograms:

$$
\begin{aligned}
\mathrm{HCG} & =R M\left(10^{-6}\right) \\
& =(200)\left(4.83 \times 10^{14}\right)\left(10^{-6}\right) \mathrm{g} \mathrm{HC} \\
& =9.66 \times 10^{10} \mathrm{~kg} \mathrm{HC} .
\end{aligned}
$$

Converting from kilograms of HC to barrels of oil (using Schmoker, 1994, fig. 19.3) gives about 1 billion barrels of $30^{\circ} \mathrm{API}$ oil. This estimate is only approximate because it is based on assumptions that are poorly constrained and may be in error. If this much oil was generated beneath the southwestern Santa Clara Valley, where is it? Experience in other petroleum basins worldwide indicates that the processes of hydrocarbon generation, expulsion, migration, and trapping are highly inefficient. For a few petroleum basins, recoverable oil may be only about 10 percent of oil generated (Schmoker, 1994) and in most petroleum basins is only a few percent (or less) of oil generated (Bird, 1994; Klemme, 1994; Magoon and Valin, 1994).

Some of the hypothetical 1 billion barrels of oil generated beneath the southwestern Santa Clara Valley (fig. 1) may be trapped in accumulations ranging in size from 1 million to a few million barrels, as suggested below, and some of these accumulations could have commercial value under certain economic conditions. Another, possibly larger, portion of the oil generated is probably trapped in small, noncommercial accumulations ranging in size from a few barrels to several thousand barrels; some of these tiny accumulations may have been tapped by the Peck well and other wells in the Los Gatos area (fig. 5). As in many other petroleum basins around the world, however, most of the oil generated beneath the southwestern Santa Clara Valley probably has been lost forever to biodegradation, oxidation, and seepage to the surface.

\section{Undiscovered Oil Resources Beneath the Southwestern Santa Clara Valley}

Do oil and gas accumulations of commercial size exist beneath the southwestern Santa Clara Valley? If so, then how big are they, how many might there be, and where are they located? These questions can be answered only by drilling many wells, but we can guess at the answers by considering previous exploration experience in coastal California.
By analogy with known oil and gas fields in the Santa Cruz Mountains and other geologically similar areas of California (Stanley, 1995a, c, d), the minimum size of a hypothetical, commercially viable oil accumulation in the southwestern Santa Clara Valley is probably about 1 to 2 million barrels. In coastal California, an average of about one commercial accumulation has been found for every 50$\mathrm{km}^{2}$ area that was tested for oil (Stanley, 1995d). We assume that the prospective region in the southwestern Santa Clara Valley generally coincides with the region in which Cenozoic deposits are at least $1 \mathrm{~km}$ thick (fig. 7) and covers an area of about 230 to $245 \mathrm{~km}^{2}$. These values, in turn, imply the existence of about five accumulations of about 1 to 2 million barrels of oil in the southwestern Santa Clara Valley and suggest a total resource no larger than 5 to 10 million barrels-a very small amount relative to the 312 million barrels of oil produced in all of California during 1996 (California Division of Oil, Gas, and Geothermal Resources, 2000). A major limitation on the amount of petroleum in the southwestern Santa Clara Valley is the small geographic size of the area relative to other California oil and gas basins, a fact recognized many years ago by Vander Leck $(1921$, p. 64), who wrote “*** it is probable that the region is underlain by Monterey shale containing a little oil, but the presence of Franciscan rocks on both sides of the valley restricts the shale to such a small area that production on a commercial scale is doubtful." Our forecast of approximately 5 to 10 million barrels of undiscovered oil resources in the southwestern Santa Clara Valley is substantially less than, and thus compatible with, our estimation that approximately 1 billion barrels of oil was generated there. Both estimates, however, are poorly constrained by geologic data and so are best regarded only as testable hypotheses, subject to revision or rejection as more information is obtained.

If about five accumulations of crude oil of about 1 million to 2 million barrels each are hidden beneath the southwestern Santa Clara Valley, where are they most likely to occur? The existence and exact locations of these hypothetical oil fields can be verified only by drilling. We suggest, however, that such accumulations would most likely occur near the Monte Vista Fault, where low-density rocks are at least $3 \mathrm{~km}$ thick (fig. 7) and where source rocks of the Miocene Monterey Formation are most likely of sufficient thermal maturity to have generated oil and gas. No deep exploratory holes have been drilled in this area, which extends from Saratoga northwestward to Cupertino (figs. 2, 6, 7). By analogy with known accumulations in other geologically similar sedimentary basins in coastal California, we speculate that oil and gas generated in the Monterey Formation may have migrated into various anticlinal, fault, and stratigraphic traps along the Monte Vista Fault. Some of these traps may occur in subthrust positions beneath the fault, where Franciscan rocks at the surface have been thrust northeastward over Miocene and younger strata (Dibblee, 1966b; Sorg and McLaughlin, 1975). Additional accumulations of oil may occur in stratigraphic traps on the east, northeast, and north sides of the basin in the cities of Campbell, Santa Clara, and Sunnyvale (figs, 2, 6, 7). 
By analogy with the wells in the Los Gatos area (figs. 5, 9; table 3), oil in these hypothetical accumulations most likely occurs in reservoirs in sandstone and fractured fine-grained rocks (mainly shale but possibly also porcelanite, chert, and carbonate rocks) within the Monterey Formation. Lesser amounts of oil may occur in sandstone reservoirs of the Santa Clara Formation, and it is remotely possible that oil might also occur in fractured rocks of the Franciscan Complex, as it does in the Hollister oil field (fig. 1; see Wilkinson, 1963, 1967; California Division of Oil and Gas, 1985). Petroleum seals may be provided by (1) fine-grained fault gouge and overthrust Franciscan rocks in the hanging walls of thrust faults, (2) unfractured shale and other fine-grained rocks in the Monterey Formation, and (3) locally thick and laterally persistent layers of impermeable clay within the Santa Clara Formation (as described by Tolman, 1934). However, much of the Santa Clara Formation and the overlying, younger Quaternary deposits consist predominantly of porous and permeable sand and gravel that might allow petroleum to escape upward to the surface and might permit freshwater to flow downward and promote physical and biological degradation of petroleum in the subsurface. Although the existence of small commercial accumulations of oil and gas in the southwestern Santa Clara Valley is distinctly possible, further petroleum exploration seems unlikely because most of the land is devoted to residential, recreational, and industrial uses.

\section{Implications for the Environment}

Naturally occurring petroleum derived from source rocks in the Miocene Monterey Formation is a potential source of surface and near-surface contamination in the southwestern Santa Clara Valley and conceivably could reach the surface in at least three ways. First, petroleum can migrate along natural pathways in such porous and permeable sedimentary deposits as sand and gravel, as well as along fractures in bedrock. Natural migration is a likely explanation for the surface occurrences of petroleum shown on Forstner's map (fig. 8) and for an oil seep, mentioned above, that formerly occurred near the Peck well. Test boreholes for a parking structure in downtown Los Gatos reportedly found oil blebs in sand and gravelly sand at about 2- to 9-m depth, but we do not know whether this oil was indigenous to the southwestern Santa Clara Valley or, alternatively, was derived from human activity, such as an oilspill or leaky fuel tank. Drillers and public agencies should be aware that oil in sedimentary deposits, ground water, or surface water in the southwestern Santa Clara Valley may represent human-caused pollution or, instead, may be of local, natural origin.

Second, oil can migrate into shallow aquifers, surface streams, or lakes by way of old wells that were improperly sealed. No occurrences of hydrocarbons in water have been reported in the Los Gatos area (fig. 5; Dave Zozaya, Santa Clara Valley Water District, oral commun., 1994), and none of the wells in this area is known to have contaminated local water supplies or the surface environment.
Third, naturally occurring petroleum might be recovered by chance when drilling water wells, engineering coreholes, and other boreholes. For example, a water well drilled in Campbell before 1960 reported traces of oil in blue clay and gravel at about 150 - to $215-\mathrm{m}$ depth. We suggest that proper precautions - possibly including blowout preventers-be considered in drilling any future deep holes in the Los Gatos, Campbell, Saratoga, and Cupertino areas, where the greatest risk of penetrating accumulations of naturally occurring oil and gas exists.

\section{Conclusions}

New geologic, geophysical, and organic-geochemical information, in combination with long-forgotten data from historical oil wells, provides important new insights into the subsurface and petroleum geology of the southwestern Santa Clara Valley (fig. 1).

Three principal lines of evidence indicate the existence of a concealed, petroleum-bearing Miocene sedimentary basin beneath the valley: (1) A conspicuous isostatic-gravity low with a maximum value of about $28 \mathrm{mGal}$ extends from Palo Alto to near Los Gatos, modeled as an asymmetric, northwest-trending body of low-density sedimentary rocks that rests on higher-density Franciscan rocks; (2) historical oil wells that penetrated low-density rocks along the margins of this gravity low recorded as much as $125 \mathrm{~m}$ of late Pliocene and (or) Quaternary nonmarine deposits that overlie more than $800 \mathrm{~m}$ of brown shale and sandstone resembling nearby outcrops of the Miocene Monterey Formation; and (3) organic-geochemical analyses of biomarkers and C-isotopic composition indicate that oil from a well in Los Gatos was derived from source rocks in the Miocene Monterey Formation and that the source rocks were thermally mature and buried at about 2,100-m depth or more.

The geologic structure of the southwest boundary of the concealed sedimentary basin is complex and largely unresolved. Several alternative interpretations of crustal structure are possible. Our preferred structural interpretation is that the concealed basin is a half-graben bounded on its southwestern margin by buried, northeast-dipping normal faults which were active during early to middle Miocene volcanism and crustal extension that, in turn, were related to passage of the northwest-migrating Mendocino triple junction. During the Pliocene and Quaternary, these Miocene rocks were deformed and overthrust by northeastward-vergent reverse and thrust faults of the Berrocal, Shannon, and Monte Vista Fault zones, which are still seismically active. This deformation was accompanied by uplift of the modern Santa Cruz Mountains and apparently was driven by compression related to local San Andreas Fault tectonics and to regional transpression along the Pacific-North American Plate boundary.

Preliminary calculations suggest that about 1 billion barrels of oil may have been generated from petroleum-source rocks within the Monterey Formation in the deepest part of the subsurface sedimentary basin between Los Gatos and 
Cupertino. Some of this oil may have moved into accumulations in anticlinal and fault traps along the Monte Vista and other faults that mark the complex structural boundary between the southwestern Santa Clara Valley and Santa Cruz Mountains. Although some of these oil accumulations may be of commercial size, exploratory drilling in this area seems unlikely because it is densely populated. Further insights into the stratigraphy, structure, seismic hazards, and petroleumresource potential of the southwestern Santa Clara Valley might be gained from conventional seismic-reflection profiling, new technologies that allow three-dimensional seismic imaging, and one or more deep stratigraphic boreholes.

\section{Acknowledgments}

We are grateful to the CDOGGR for allowing us to examine and copy well records on file in their Santa Maria and Sacramento offices. In particular, we thank Ed Brannon and Ross Brunetti of the CDOGGR for calling our attention to the occurrence of oil wells and seeps in the Los Gatos area (fig. 5) and for providing a copy of the unpublished map by Forstner (fig. 8). James F. Davis and Sylvia L. Bender of the California Division of Mines and Geology assisted in the search for the source of Forstner's map. Donald A. Peck kindly allowed us to collect samples of oil from the well on his property in Los Gatos, and Michael Cox and Tom Borah helped us obtain samples of oil-bearing mercury ore from near New Almaden. Don Marcott and Ed Platz of the Santa Clara County Surveyors helped identify the locations of the H.H. Main, McGrath, and other properties. Bill Wulf, John Bagerly, and the staff of the Los Gatos Library helped locate newspaper articles and other historical information on the Los Gatos wells. Charles Marler of Jensen International, Inc., Coffeyville, Kans., provided a copy of the original sales record for the pump unit on the Peck well. Mike Nelson of the City of Santa Paula Union Oil Museum, Santa Paula, Calif., supplied information on cable tool drilling. Colin F. Williams of the USGS provided the estimates of subsurface temperatures listed in table 9. Zenon Valin of the USGS helped collect oil samples, prepared the reproduction of Forstner's map (fig. 8), and assisted in many other ways. Robert E. Garrison of the University of California, Santa Cruz, and David W. Andersen of San Jose State University reviewed the manuscript, and Charles L. Powell II of the USGS reviewed geologic names.

\section{References Cited}

Adam, D.P., McLaughlin, R.J., Sorg, D.H., Adams, D.P., Forester, R.M., and Repenning, C.A., 1983, An animal- and plant-fossil assemblage from the Santa Clara Formation (Pliocene and Pleistocene), Saratoga, California, in Andersen, D.W., and Rymer, M.J., eds., Tectonics and sedimentation along faults of the San Andreas system: Los Angeles, Society of Economic Paleontologists and Mineralogists, Pacific Section, p. 105-110.

Addicott, W.O., 1968, Mid-Tertiary zoogeographic and paleogeographic discontinuities across the San Andreas fault, California, in Dickin- son, W.R., and Grantz, Arthur, eds., Proceedings of conference on geologic problems of the San Andreas fault system: Stanford University Publications in Geological Sciences, v. 11, p. 145-165.

1969, Late Pliocene mollusks from San Francisco Peninsula, California, and their paleogeographic significance: California Academy of Sciences Proceedings, ser. 4, v. 37, no. 3, p. 57-93.

Angell, Michael, and Crampton, T.A., 1996, Quaternary contractional faulting and folding northeast of the San Andreas fault, Portola Valley-Palo Alto, California, in Jayko, A.S., and Lewis, S.D., compilers, Toward assessing the seismic risk associated with blind faults, San Francisco Bay Region, California: U.S. Geological Survey Open-File Report 96-267, p. 51-64.

Bailey, E.H., and Everhart, D.L., 1964, Geology and quicksilver deposits of the New Almaden district, Santa Clara County, California: U.S. Geological Survey Professional Paper 360, 206 p.

Barwise, A.J.G., Duncan, A.D., and Pepper, A.S., 1991, The kinetics of molecular maturity reactions - calibration of organofacies effects using basin data, in Manning, D.A.C., ed., Organic geochemistry-advances and applications in the natural environment: Manchester, U.K., Manchester University Press, p. 275-277.

Baskin, D.K., and Peters, K.E., 1992, Early generation characteristics of a sulfur-rich Monterey kerogen: American Association of Petroleum Geologists Bulletin, v. 76, no. 1, p. 1-13.

Beaulieu, J.D., 1970, Cenozoic stratigraphy of the Santa Cruz Mountains, California, and inferred displacement along the San Andreas fault: Stanford, Calif., Stanford University, Ph.D. thesis, 202 p.

Berggren, W.A., Kent, D.V., Swisher, C.C., III, and Aubry, Marie-Pierre, 1995, A revised Cenozoic geochronology and chronostratigraphy, in Berggren, W.A., Kent, D.V., and Hardenbol, Jan, eds., Geochronology, time scales, and global stratigraphic correlation: Society for Sedimentary Geology Special Publication 54, p. 129-212.

Beyer, L.A., 1980, Borehole gravity program of the U.S. Geological Survey (1963-1975) — brief history and basic data: U.S. Geological Survey Open-File Report 80-903, $76 \mathrm{p}$.

Bird, K.J., 1994, Ellesmerian(!) petroleum system, North Slope of Alaska, U.S.A., in Magoon, L.B., Jr., and Dow, W.G., eds., The petroleum system - from source to trap: American Association of Petroleum Geologists Memoir 60, p. 339-358.

Blake, M.C., Jr., Howell, D.G., and Jayko, A.S., 1984, Tectonostratigraphic terranes of the San Francisco Bay region, in Blake, M.C., Jr., ed., Franciscan geology of northern California: Los Angeles, Society of Economic Paleontologists and Mineralogists, Pacific Section Field Trip Guidebook, v. 43, p. 5-22.

Blondeau, Alphonse, and Brabb, E.E., 1983, Large foraminifers of Eocene age from the Coast Ranges of California, in Brabb, E.E., ed., Studies in Tertiary stratigraphy of the California Coast Ranges: U.S. Geological Survey Professional Paper 1213, p. 41-48.

Brabb, E.E., 1993, Preliminary geologic map of the onshore part of the Palo Alto 1:100,000 quadrangle, California: U.S. Geological Survey Open-File Report 93-271, 21 p., scale 1:62,500.

Brabb, E.E., and Hanna, W.F., 1981, Maps showing aeromagnetic anomalies, faults, earthquake epicenters, and igneous rocks in the southern San Francisco Bay region, California: U.S. Geological Survey Geophysical Investigations Map GP-932, scale 1:125,000.

Brocher, T.M., Ruebel, A.L., and Brabb, E.E., 1997, Compilation of 59 sonic and density logs from 51 oil test wells in the San Francisco Bay area, California: U.S. Geological Survey Open-File Report $97-687,75 \mathrm{p}$.

Bruntz, G. G., 1971, The history of Los Gatos, gem of the foothills: Fresno, Calif., Valley Publishers, $173 \mathrm{p}$.

Bürgmann, Roland, Arrowsmith, Ramón, Dumitru, T.A., and McLaughlin, R.J., 1994, Rise and fall of the southern Santa Cruz Mountains, Cali- 
fornia, from fission tracks, geomorphology, and geodesy: Journal of Geophysical Research, v. 99, no. B10, p. 20181-20202.

California Department of Water Resources, 1967, Evaluation of ground water resources, south bay: Bulletin 118-1, app. A (Geology), $153 \mathrm{p}$.

1975, Evaluation of ground water resources, South San Francisco Bay: Bulletin 118-1, v. 3 (Northern Santa Clara County area), $153 \mathrm{p}$.

1993, Dams within jurisdiction of the State of California: Bulletin 17-93, $125 \mathrm{p}$.

California Division of Oil and Gas, 1982a, California oil and gas fields, northern California (4th ed.): Publication TR10, n.p.

1982b, Oil and gas prospect wells drilled in California through 1980 (2d ed.): Publication TR01, 258 p.

-1985, California oil and gas fields, central California (3rd ed.): Publication TR11, n.p.

1991, Regional wildcat map showing wells not on Division of Oil and Gas field maps: Map W3-10, scale approx 1:125,000.

California Division of Oil, Gas, and Geothermal Resources, 1996, 1995 Annual Report of the State Oil and Gas Supervisor: Publication PR06, $279 \mathrm{p}$.

2000, 1999 Annual Report of the State Oil and Gas Supervisor: Publication PR06, $243 \mathrm{p}$.

California Water Resources Board, 1955, Santa Clara Valley investigation: Bulletin 7, $154 \mathrm{p}$.

Campbell, K.W., Thenhaus, P.C., Sanginés, E.M., and Seligson, H.A., 1995, Expected ground shaking intensities from a magnitude 7 earthquake on the Monte Vista-Shannon and Santa Clara thrust faults, Santa Clara Valley, Santa Clara County, California, in Sanginés, E.M., Andersen, D.W., and Buising, A.B., eds., Recent geologic studies in the San Francisco Bay area: Los Angeles, Society of Economic Paleontologists and Mineralogists, Pacific Section Guidebook, v. 76, p. 161-172.

Clark, W.O., 1924, Ground water in Santa Clara Valley, California: U.S. Geological Survey Water-Supply Paper 519, 209 p.

Clarke, S.H., Jr., and Nilsen, T.H., 1973, Displacement of Eocene strata and implications for the history of offset along the San Andreas fault, central and northern California, in Kovach, R.L., and Nur, Amos, eds., Proceedings of the conference on tectonic problems of the San Andreas fault system: Stanford University Publications in Geological Sciences, v. 13, p. 358-367.

Clayton, J.L., and Swetland, P.J., 1978, Subaerial weathering of sedimentary organic matter: Geochimica et Cosmochimica Acta, v. 42, no. 2, p. 305-312.

Clementz, D.M., Demaison, G.J., and Daly, A.R., 1979, Well site geochemistry by programmed pyrolysis: Annual Offshore Technology Conference, 11th, Houston, Tex., 1979, Proceedings, v. 1, p. 465-470.

Cotton, W.R., Cole, W.F., and Wallace, J.M., 1994, Geologic constraints on the Quaternary tectonic history of range-front deformation, northeastern margin of the central Santa Cruz Mountains, California [abs.]: Eos (American Geophysical Union Transactions), v. 75, no. 44, p. 682.

Crain, W.E., Mero, W.E., and Patterson, Don, 1985, Geology of the Point Arguello discovery: American Association of Petroleum Geologists Bulletin, v. 69, no. 4, p. 537-545.

1987, Geology of the Point Arguello field, in Ingersoll, R.V., and Ernst, W.G., eds., Cenozoic basin development of coastal California (Rubey volume 6): Englewood Cliffs, N.J., Prentice Hall, p. 407-426.

Crawford, J.J., 1896, Thirteenth report (third biennial) of the State mineralogist, for the two years ending September 15, 1896: Sacramento, California State Mining Bureau, 726 p.
Crowell, J.C., 1959, Problems of fault nomenclature: American Association of Petroleum Geologists Bulletin, v. 43, no. 11, p. 2653-2674.

Curiale, J.A., Cameron, Douglas, and Davis, D.V., 1985, Biological marker distribution and significance in oils and rocks of the Monterey Formation, California: Geochimica et Cosmochimica Acta, v. 49, no. 1, p. 271-288.

Cummings, J.C., 1968, The Santa Clara Formation and possible postPliocene slip on the San Andreas fault in central California, in Dickinson, W.R., and Grantz, Arthur, Proceedings of conference on geologic problems of San Andreas fault system: Stanford University Publications in Geological Sciences, v. 6, p. 191-207.

Cummings, J.C., Touring, R.M., and Brabb, E.E., 1962, Geology of the northern Santa Cruz Mountains, California, in Bowen, 0.E., Jr., ed., Geologic guide to the gas and oil fields of northern California: California Division of Mines and Geology Bulletin 181, p. 179-220.

Dalrymple, G.B., 1979, Critical tables for conversion of K-Ar ages from old to new constants: Geology, v. 7, no. 11, p. 558-560.

Davis, F.F., and Jennings, C.W., 1954, Mines and mineral resources of Santa Clara County, California: California Journal of Mines and Geology, v. 50, no. 2, p. 321-430.

Davis, T.L., Namson, J.S., and Gordon, Stuart, 1996, Structure and hydrocarbon exploration in the transpressive basins of southern California, in Abbott, P.L., and Cooper, J.D., eds., Field Conference Guide, 1996: Bakersfield, Calif., American Association of Petroleum Geologists, Pacific Section Guidebook, v. 73/Society of Economic Paleontologists and Mineralogists, Pacific Section Book 80, p. 189-238.

Dibblee, T.W., Jr., 1966a, Evidence for cumulative offset on the San Andreas fault in central and northern California, in Bailey, E.H., ed., Geology of northern California: California Division of Mines and Geology Bulletin 190, p. 375-384.

1966b, Geology of the Palo Alto quadrangle, Santa Clara and San Mateo Counties, California: California Division of Mines and Geology Map Sheet 8, scale 1:62,500.

Dunham, J.B., and Blake, G.H., 1987, Guide to coastal outcrops of the Monterey Formation of western Santa Barbara County, California: Los Angeles, Society of Economic Paleontologists and Mineralogists, Pacific Section, Book 53, 36 p.

Espitalié, Jean, Madec, Marcel, Tissot, B.P., Mennig, J.J., and Leplat, Paul, 1977, Source rock characterization method for exploration: Offshore Technology Conference, 9th, Houston, Tex., 1977, Preprints, v. 3, p. 439-444.

Espitalié, Jean, Marquis, François, and Borsony, I., 1984, Geochemical logging, in Voorhees, K.J., ed., Analytical pyrolysis: London, Butterworth and Co., p. 276-304.

Fio, J.L., and Leighton, D.A., 1995, Geohydrologic framework, historical development of the ground-water system, and general hydrologic and water-quality conditions in 1990, south San Francisco Bay and peninsula area, California: U.S. Geological Survey Open-File Report 94-357, $46 \mathrm{p}$.

Forstner, William, 1903, The quicksilver resources of California: California Mining Bureau Bulletin 27, 273 p.

1904, The quicksilver deposits of California: Engineering and Mining Journal, v. 78, no. 10 (Sept. 8, 1904), p. 385-386.

1907a, Copper in Shasta County, California: Mining and Scientific Press, v. 94, no. 20 (May 18, 1907), p. 625-626.

1907b, Ore deposits in serpentine: Mining and Scientific Press, v. 95, no. 4 (July 27, 1907), p. 121-122.

1908a, Copper deposits in the western foothills of the Sierra Nevada: Mining and Scientific Press, v. 96, no. 22 (May 30, 1908), p. 743-748.

1908b, The genesis of the copper ores in Shasta County, west 
of the Sacramento River: Mining and Scientific Press, v. 97, no. 8 (Aug. 22, 1908), p. 261-262.

1909a, Geology of the Coalinga oil district: Mining and Scientific Press, v. 99, no. 17 (0ct. 23, 1909), p. 566-567.

1909b, Historical geology of California: Mining and Scientific Press, v. 98, no. 25 (June 19, 1909), p. 853-858.

1909c, Oil measures in the Coalinga district: Mining and Scientific Press, v. 98, no. 11 (Mar. 13, 1909), p. 386-387.

1910, Occurrence of oil and gas: Mining and Scientific Press, v. 101, no. 20 (Nov. 12, 1910), p. 634-638.

1911, Oil fields south of Coalinga: Mining and Scientific Press, v. 102, no. 21 (May 27, 1911), p. 722-724.

Graham, S.A., Stanley, R.G., Bent, J.V., and Carter, J.B., 1989, Oligocene and Miocene paleogeography of central California and displacement along the San Andreas fault: Geological Society of America Bulletin, v. 101, no. 5, p. 711-730.

Harbert, William, and Cox, Allan, 1989, Late Neogene motion of the Pacific Plate: Journal of Geophysical Research, v. 94, no. B3, p. 3052-3064.

Haugerud, R.A., and Ellen, S.D., 1990, Coseismic ground deformation along the northeast margin of the Santa Cruz Mountains, in Schwartz, D.P., and Ponti, D.J., eds., 1990, Field guide to neotectonics of the San Andreas fault system, Santa Cruz Mountains, in light of the 1989 Loma Prieta earthquake: U.S. Geological Survey Open-File Report 90-274, p. 32-36.

Hay, E.A., Cotton, W.R., and Hall, N.T., 1980, Shear couple tectonics and the Sargent-Berrocal fault system in northern California, in Streitz, Robert, and Sherburne, Roger, eds., Studies of the San Andreas fault zone in northern California: California Division of Mines and Geology Special Report 140, p. 41-49.

Heasler, H.P., and Surdam, R.C., 1983, A thermally subsiding basin model for the maturation of hydrocarbons in the Pismo Basin, California, in Isaacs, C.M., and Garrison, R.E., eds., Petroleum generation and occurrence in the Miocene Monterey Formation, California: Los Angeles, Society of Economic Paleontologists and Mineralogists, Pacific Section, p. 69-74.

Helley, E.J., Lajoie, K.R., Spangle, W.E., and Blair, M.L., 1979, Flatland deposits of the San Francisco Bay region, California-their geology and engineering properties, and their importance to comprehensive planning: U.S. Geological Survey Professional Paper 943, $88 \mathrm{p}$.

Herrman, A.T., and Herrman, Charles, 1890, Official map of the County of Santa Clara, California, compiled from U.S. surveys, county records, and private surveys, and the tax list of 1889 by order of the Honorable Board of Supervisors: San Francisco, Britton and Rey, scale approx 1:39,000 [available for public inspection in the offices of the Santa Clara County Surveyors, San Jose, Calif.].

Hill, M.L., and Dibblee, T.W., Jr., 1953, San Andreas, Garlock, and Big Pine faults, California, a study of the character, history and tectonic significance of their displacements: Geological Society of America Bulletin, v. 64, no. 4, p. 443-458.

Hitchcock, C.S., Kelson, K.I., and Thompson, S.C., 1994, Geomorphic investigations of deformation along the northeastern margin of the Santa Cruz Mountains: U.S. Geological Survey Open-File Report 94-187, $50 \mathrm{p}$.

Huguenin, Emile, and Castello, W.O., 1921, Santa Clara County: California State Mining Bureau, State Mineralogist Report, v. 17, p. 180-227.

Hunt, J.M., 1996, Petroleum geochemistry and geology (2d ed.): New York, W.H. Freeman, 743 p.

Irwin, W.P., 1960, Geologic reconnaissance of the northern Coast Ranges and Klamath Mountains, California, with a summary of the mineral resources: California Division of Mines Bulletin 179, 80 p.

Iwamura, T.I., 1995, Hydrogeology of the Santa Clara and Coyote Valleys groundwater basins, California, in Sanginés, E.M., Andersen, D.W., and Buising, A.B., eds., Recent geologic studies in the San Francisco Bay area: Los Angeles, Society of Economic Paleontologists and Mineralogists, Pacific Section Guidebook v. 76, p. 173-192.

Jachens, R.C., and Griscom, Andrew, 1985, An isostatic residual gravity map of California - a residual map for interpretation of anomalies from intracrustal sources, in Hinze, W.J. ed., The utility of regional gravity and magnetic anomaly maps: Tulsa, Okla., Society of Exploration Geophysicists, p. 347-359.

Jachens, R.C., Griscom, Andrew, and Roberts, C.W., 1995, Distribution of Cenozoic deposits in the southern San Francisco Bay trough from gravity and magnetic anomalies [abs.]: American Association of Petroleum Geologists Bulletin, v. 79, no. 4, p. 588.

Jachens, R.C., and Moring, B.C., 1990, Maps of the thickness of Cenozoic deposits and the isostatic residual gravity over basement for Nevada: U.S. Geological Survey Open-File Report 90-404, 15 p., scale 1:1,000,000, 2 sheets.

Jachens, R.C., and Roberts, C.W., 1993, Aeromagnetic map of the San Francisco Bay area, California: U.S. Geological Survey Geophysical Investigations Map GP-1007, scale approx 1:286,500.

Jayko, A.S., 1996, Active folds and blind thrusts, San Francisco Bay region, an overview, in Jayko, A.S., and Lewis, S.D., compilers, Toward assessing the seismic risk associated with blind faults, San Francisco Bay Region, California: U.S. Geological Survey Open-File Report 96-267, p. 4-27.

Jenkins, O.P., 1943, Geologic formations and economic development of the oil and gas fields of California: California Division of Mines Bulletin 118, $773 \mathrm{p}$.

Johnson, A.l., Moston, R.P., and Morris, D.A., 1968, Physical and hydrologic properties of water-bearing deposits in subsiding areas in central California: U.S. Geological Survey Professional Paper 497-A, $71 \mathrm{p}$.

Katz, B.J., 1983, Limitations of Rock-Eval pyrolysis for typing organic matter: Organic Geochemistry, v. 4, no. 3/4, p. 195-199.

Kleinpell, R.M., 1938, Miocene stratigraphy of California: Tulsa, Okla., American Association of Petroleum Geologists, 450 p.

1980, History of stratigraphic paleontology of West Coast Tertiary, in Kleinpell, R.M., ed., The Miocene stratigraphy of California revisited; also, Pliocene biostratigraphy of California: Tulsa, Okla., American Association of Petroleum Geologists Studies in Geology, no. 11, p. 4-53.

Klemme, H.D., 1994, Petroleum systems of the world involving Upper Jurassic source rocks, in Magoon, L.B., Jr., and Dow, W.G., eds., The petroleum system - from source to trap: American Association of Petroleum Geologists Memoir 60, p. 51-72.

Kovach, R.L., and Page, B.M., 1995, Seismotectonics near Stanford University: California Geology, v. 48, no. 4, p. 91-98.

Krueger, M.L., 1943, Moody Gulch oil field, in Geologic formations and economic development of the oil and gas fields of California: California Division of Mines Bulletin 118, p. 477.

Kvenvolden, K.A., Hostettler, F.D., Carlson, P.R., Rapp, J.B., Threlkeld, C.N., and Warden, Augusta, 1995, Ubiquitous tar balls with a California-source signature on the shorelines of Prince William Sound, Alaska: Environmental Science and Technology, v. 29, no. 10, p. 2684-2694.

Langenheim, V.E., Schmidt, K.M., and Jachens, R.C., 1997, Coseismic deformation and range-front thrusting along the southwestern margin of the Santa Clara Valley, California: Geology, v. 25, p. 1091-1094. 
Lanphere, M.A., Champion, D. E., Clynne, M.A., and Muffler, L.J.P., 1999, Revised age of the Rockland tephra, northern California-implications for climate and stratigraphic reconstructions in the western United States: Geology, v. 27, no. 2, p. 135-138.

Larue, D.K., 1986, Organic matter in limestone and melange matrix from the Franciscan and Cedros subduction complexes, in Abbott, P.L., ed., Cretaceous stratigraphy of North America: Los Angeles, Society of Economic Paleontologists and Mineralogists, Pacific Section, p. 211-221.

1991, Organic matter in the Franciscan and Cedros subduction complexes: the problems of "instantaneous maturation" and "missing petroleum" in accretionary prisms: Marine and Petroleum Geology, v. 8, no. 4, p. 468-482.

Levander, Alan, Humphreys, E.D., Ekstrom, Goran, Meltzer, A.S., and Shearer, P.M., 1999, Proposed project would give unprecedented look under North America: Eos (American Geophysical Union Transactions), v. 80, no. 22, p. 245-251.

Levorsen, A.I., 1967, Geology of petroleum (2d ed.): San Francisco, Calif., W.H. Freeman and Co., $724 \mathrm{p}$.

Lewan, M.D., Bjoroy, Malvin, and Dolcater, D.L., 1986, Effects of thermal maturation on steroid hydrocarbons as determined by hydrous pyrolysis of Phosphoria Retort Shale: Geochimica et Cosmochimica Acta, v. 50, no. 9, p. 1977-1987.

Leythaeuser, Detlev, 1973, Effects of weathering on organic matter in shales: Geochimica et Cosmochimica Acta, v. 37, no. 1, p. 113-120.

Leythaeuser, Detlev, and Schwarzkopf, T.A., 1986, The pristane/n-heptadecane ratio as an indicator for recognition of hydrocarbon migration effects: Organic Geochemistry, v. 10, no. 1-3, p. 191-197.

Lillis, P.G., 1994, Soda Lake-Painted Rock(!) petroleum system in the Cuyama basin, California, U.S.A., in Magoon, L.B., III, and Dow, W.G., eds., The petroleum system — from source to trap: American Association of Petroleum Geologists Memoir 60, p. 437-451.

Lillis, P.G., Magoon, L.B., Stanley, R.G., McLaughlin, R.J., and Warden, Augusta, 2001, Characterization of northern California petroleum by stable carbon isotopes: U.S. Geological Survey Open-File Report 99-164, $13 \mathrm{p}$.

Mackenzie, A.S., 1984, Applications of biological markers in petroleum geochemistry, in Brooks, Jim, and Welte, Dietrich, eds., Advances in petroleum geochemistry: London, Academic Press, v. 1, p. 115-214.

Magoon, L.B., Lillis, P.G., Warden, Augusta, Stanley, R.G., MacKevett, N.H., and Castaño, Jack, 1995, Carbon isotopic compositions identify four petroleum types in northern California [abs.]: American Association of Petroleum Geologists Bulletin, v. 79, no. 4, p. 592.

Magoon, L.B., and Valin, Z.C., 1994, Overview of petroleum-system case studies, in Magoon, L.B., Jr., and Dow, W.G., eds., The petroleum system - from source to trap: American Association of Petroleum Geologists Memoir 60, p. 329-338.

Matthews, Vincent, III, 1976, Correlation of Pinnacles and Neenach volcanic formations and their bearing on San Andreas fault problem: American Association of Petroleum Geologists Bulletin, v. 60, no. 12, p. 2128-2141.

McLaughlin, R.J., 1971, Geologic map of the Sargent fault zone in the vicinity of Mount Madonna, Santa Clara County, California: U.S. Geological Survey Open-File Map, scale 1:12,000, 2 sheets.

1974, The Sargent-Berrocal fault zone and its relation to the San Andreas fault system in the southern San Francisco Bay region and Santa Clara Valley, California: U.S. Geological Survey Journal of Research, v. 2, no. 5, p. 593-598.

1990, Sargent fault zone at Loma Prieta, in Schwartz, D.P., and
Ponti, D.J., eds., Field guide to neotectonics of the San Andreas fault system, Santa Cruz Mountains, in light of the 1989 Loma Prieta earthquake: U.S. Geological Survey Open-File Report 90-274, p. 19-22.

McLaughlin, R.J., Clark, J.C., Brabb, E.E., and Helley, E.J., 1991a, Geologic map and structure sections of the Los Gatos 7.5-minute quadrangle, Santa Clara and Santa Cruz Counties, California: U.S. Geological Survey Open-File Report 91-593, 48 p., scale 1: 24,000 .

McLaughlin, R.J., Clark, J.C., Brabb, E.E., Helley, E.J., and Colon, C.J., 2001, Geologic maps and structure sections of the southwestern Santa Clara Valley and southern Santa Cruz Mountains, Santa Clara and Santa Cruz Counties, California: U.S. Geological Survey Miscellaneous Field Studies Map MF-2373, scale 1:24,000.

McLaughlin, R.J., Elder, W.P., and McDougall, Kristin, 1991b, Tectonic framework of the Loma Prieta area, in Sloan, Doris, and Wagner, D.L., eds., Geologic excursions in northern California-San Francisco to the Sierra Nevada: California Division of Mines and Geology Special Publication 109, p. 45-54.

McLaughlin, R.J., Jachens, R.C., Stanley, R.G., Jayko, A.S., Langenheim, V.E., Wentworth, C.M. and McDougall, K.A., 1997a, Neogene compressional and extensional tectonism northeast of the San Andreas fault, southwestern Santa Clara Valley, California [abs.]: Geological Society of America Abstracts with Programs, v. 29, no. 5, p. 28-53.

McLaughlin, R.J., Langenheim, V.E., Jachens, R.C., Jayko, A.S., Stanley, R.G., Valin Z.C., and Schmidt, K.M., 1997b, Neogene transpressional range-front deformation, southwestern Silicon Valley, San Francisco Bay region, California [abs.]: Eos (American Geophysical Union Transactions), v. 78, no. 46, p. F435.

McLaughlin, R.J., Langenheim, V.E., Schmidt, K.M., Jachens, R.C., Stanley, R.G., Jayko, A.S., McDougall, K.A., Tinsley, J.C., and Valin, Z.C., 1999, Neogene contraction between the San Andreas fault and the Santa Clara Valley, San Francisco Bay Region, California: International Geology Review, v. 41, no. 1, p. 1-30.

McLaughlin, R.J., Oppenheimer, D.H., Helley, E.J., and Sébrier, Michel, 1992, The Lexington fault zone - a north-south link between the San Andreas fault and range-front thrust system, Los Gatos, California [abs.]: Geological Society of America Abstracts with Programs, v. 24, no. 5, p. 69.

McLaughlin, R.J., Sliter, W.V., Sorg, D.H., Russell, P.C., and Sarna-Wojcicki, A.M., 1996a, Large-scale right-slip displacement on the east San Francisco Bay region fault system, California-implications for location of late Miocene to Pliocene Pacific plate boundary: Tectonics, v. 15, no. 1, p. 1-18.

McLaughlin, R.J., Sorg, D.H., and Helley, E.J., 1996b, Constraints on slip histories of thrust faults of the southwestern San Francisco Bay area from geologic mapping investigations, in Jayko, A.S., and Lewis, S.D., compilers, Toward assessing the seismic risk associated with blind faults, San Francisco Bay Region, California: U.S. Geological Survey Open-File Report 96-267, p. 65-70.

McLaughlin, R.P., and Waring, C.A., 1914, Petroleum industry of California: California State Mining Bureau Bulletin 69, 519 p.

McNutt, S.R., 1990, Summary of damage and losses caused by the Loma Prieta earthquake, in McNutt, S.R., and Sydnor, R.H., eds, The Loma Prieta (Santa Cruz Mountains), California, earthquake of 17 October 1989: California Division of Mines and Geology Special Publication 104, p. 131-138.

McNutt, S.R., and Toppozada, T.R., 1990, Seismological aspects of the 17 October 1989 earthquake, in McNutt, S.R., and Sydnor, R.H., eds, The Loma Prieta (Santa Cruz Mountains), California, earthquake of 17 October 1989: California Division of Mines and Geology Special 
Publication 104, p. 11-27.

Meyer, C.E., Sarna-Wojcicki, A.M., Hillhouse, J.W., Woodward, M.J., Slate, J.L., and Sorg, D.H., 1991, Fission-track age $(400,000 \mathrm{yr})$ of the Rockland tephra, based on inclusion of zircon grains lacking fossil fission tracks: Quaternary Research, v. 35, no. 3, p. 367-382.

Montgomery, D.R., 1990, Representative damage photographs from the Loma Prieta earthquake, in McNutt, S.R., and Sydnor, R.H., eds, The Loma Prieta (Santa Cruz Mountains), California, earthquake of 17 October 1989: California Division of Mines and Geology Special Publication 104, p. 113-119.

Nakata, J.K., Sorg, D.H., Russell, P.C., Meyer, C.E., Wooden, Joseph, Lanphere, M.A., McLaughlin, R.J., Sarna-Wojcicki, A.M., Saburomaru, J.Y., Pringle, M.S., and Drinkwater, James, 1993, New radiometric ages and tephra correlations from the San Jose and the northeastern part of the Monterey 1:100,000 map quadrangles, California: Isochron/West, no. 60, p. 19-32.

Page, B.M., and Engebretson, D.C., 1984, Correlation between the geologic record and computed plate motions for central California: Tectonics, v. 3, no. 2, p. 133-155.

Page, B.M., Ingle, J.C., and Kovach, R.L., 1996, Quaternary diapir of claystone in faulted anticline, Stanford, California: California Geology, v. 49, no. 3, p. 55-67.

Page, B.M., and Tabor, L.L., 1967, Chaotic structure and décollement in Cenozoic rocks near Stanford University, California: Geological Society of America Bulletin, v. 78, no. 1, p. 1-12.

Pampeyan, E.H., 1993, Geologic map of the Palo Alto and part of the Redwood Point 7 1/2' quadrangles, San Mateo and Santa Clara Counties, California: U.S. Geological Survey Miscellaneous Investigations Series Map I-2371, scale 1:24,000.

Peabody, C.E., 1993, The association of cinnabar and bitumen in mercury deposits of the California Coast Ranges, in Parnell, John, Kucha, Henryk, and Landais, Patrick, eds, Bitumens in ore deposits: Society for Geology Applied to Mineral Deposits Special Publication 9, p. 178-209.

Peters, K.E., 1986, Guidelines for evaluating petroleum source rock using programmed pyrolysis: American Association of Petroleum Geologists Bulletin, v. 70, no. 3, p. 318-329.

Peters, K.E., and Moldowan, J.M., 1993, The biomarker guide-interpreting molecular fossils in petroleum and ancient sediments: Englewood Cliffs, N.J., Prentice Hall, 363 p.

Plafker, George, and Galloway, J.P., eds., 1989, Lessons learned from the Loma Prieta, California, earthquake of October 17, 1989: U.S. Geological Survey Circular 1045, 48 p.

Prescott, W.H., and Burford, R.O., 1976, Slip on the Sargent fault: Seismological Society of America Bulletin, v. 66, no. 3, p. 1013-1016.

Redwine, L.E., 1981, Hypothesis combining dilation, natural hydraulic fracturing, and dolomitization to explain petroleum reservoirs in Monterey Shale, Santa Maria area, California, in Garrison, R.E., and Douglas, R.O., eds., The Monterey Formation and related siliceous rocks of California: Los Angeles, Society of Economic Paleontologists and Mineralogists, Pacific Section, p. 221-248.

Reed, W.E., 1977, Molecular compositions of weathered petroleum and comparison with its possible source: Geochimica et Cosmochimica Acta, v. 41, no. 2, p. 237-247.

Regan, L.J., Jr., and Hughes, A.W., 1949, Fractured reservoirs of Santa Maria district, California: American Association of Petroleum Geologists Bulletin, v. 33, no. 1, p. 32-51.

Rintoul, William, 1978, Spudding in-recollections of pioneer days in the California oil fields: San Francisco, California Historical Society, $240 \mathrm{p}$.

Robbins, S.L., 1971, Gravity and magnetic data in the vicinity of the Calaveras, Hayward, and Silver Creek faults near San Jose,
California: U.S. Geological Survey Professional Paper 750-B, p. B128-B139.

Roberts, C.W., and Jachens, R.C., 1993, Isostatic residual gravity map of the San Francisco Bay area, California: U.S. Geological Survey Geophysical Investigations Map GP-1006, scale approx $1: 286,500$.

Roehl, P.0., 1981, Dilation brecciation-a proposed mechanism of fracturing, petroleum expulsion, and dolomitization in the Monterey Formation, California, in Garrison, R.E., and Douglas, R.O., eds., The Monterey Formation and related siliceous rocks of California: Los Angeles, Society of Economic Paleontologists and Mineralogists, Pacific Section, p. 285-315.

Sarna-Wojcicki, A.M., Lajoie, K.R., Meyer, C.E., Adam, D.P., and Rieck, H.J., 1991, Tephrochronologic correlation of upper Neogene sediments along the Pacific margin, conterminous United States, in Morrison, R.B., ed., Quaternary nonglacial geology-conterminous U.S., v. K-2 of The geology of North America: Boulder, Colo., Geological Society of America, p. 117-140.

Sarna-Wojcicki, A.M., Meyer, C.E., Bowman, H.R., Hall, N.T., Russell, P.C., Woodward, M.J., and Slate, J.L., 1985, Correlation of the Rockland ash bed, a 400,000-year-old stratigraphic marker in northern California and western Nevada, and implications for middle Pleistocene paleogeography of central California: Quaternary Research, v. 23, no. 2, p. 236-257.

Sarna-Wojcicki, A.M., Lanphere, M.A., Champion, D. E., Clynne, M.A., and Muffler, L.J.P., 2000, Revised age of the Rockland tephra, northern California-implications for climate and stratigraphic reconstructions in the Western United States-discussion and reply: Geology, v. 28, no. 3, p. 286-287.

Schmidt, K.M., Ellen, S.D., Haugerud, R.A., Peterson, D.M., and Phelps, G.A., 1995, Breaks in pavement and pipes as indicators of rangefront faulting resulting from the 1989 Loma Prieta earthquake near the southwest margin of the Santa Clara Valley, California: U.S. Geological Survey Open-File Report 95-820, 33 p.

Schmidt, K.M., Langenheim, V.E., Ellen, S.D., and Jachens, R.C., 1996, Damage patterns from the 1989 Loma Prieta earthquake along the frontal thrust-fault system, Santa Clara Valley, California-implications for strain partitioning along the San Andreas fault [abs.]: Eos (American Geophysical Union Transactions), v. 77, no. 46, p. F742.

Schmoker, J.W., 1994, Volumetric calculation of hydrocarbons generated, in Magoon, L.B., Jr., and Dow, W.G., eds., The petroleum system - from source to trap: American Association of Petroleum Geologists Memoir 60, p. 323-326.

Schwartz, S.Y., Orange, D.L., and Anderson, R.S., 1994, Complex fault interactions in a restraining bend on the San Andreas fault, southern Santa Cruz Mountains, California, in Simpson, R.W., ed., The Loma Prieta, California, earthquake of October 17, 1989-tectonic processes and models: U.S. Geological Survey Professional Paper 1550-F, p. F49-F54.

Sébrier, Michel, McLaughlin, R.J., Lajoie, K.R., and Oppenheimer, D.H., 1992, Fault kinematics in the San Francisco Peninsula area-is the 1989 Loma Prieta earthquake anomalous? [abs.]: Eos (American Geophysical Union Transactions), v. 73, no. 43, p. 589.

Seifert, W.K., and Moldowan, J.M., 1979, The effect of biodegradation on steranes and terpanes in crude oils: Geochimica et Cosmochimica Acta, v. 43, no. 1, p. 111-126.

Seifert, W.K., Moldowan, J.M., Smith, G.W., and Whitehead, E.V., 1978, First proof of a structure of $\mathrm{C}_{28}$-pentacyclic triterpane in petroleum: Nature, v. 271, no. 5644, p. 436-437.

Short, W.R., 1986, Geology of the Santa Teresa Hills, Santa Clara County, California: Hayward, California State University, M.S. 
thesis, $112 \mathrm{p}$.

Sliter, W.V., and McGann, Mary, 1992, Age and correlation of the Calera Limestone in the Permanente terrane of northern California: U.S. Geological Survey Open-File Report 92-306, 27 p.

Sliter, W.V., Murchey, B.L., McLaughlin, R.J., and Kistler, R.W., 1991, Permanente terrane-history of Early Cretaceous seamount formation in the eastern Pacific [abs.]: Geological Society of America Abstracts with Programs, v. 23, no. 2, p. 98.

Snyder, D.B., Roberts, C.W., Saltus, R.W., and Sikora, R.F., 1982, A magnetic tape containing the principal facts of 64,026 gravity stations in California: National Technical Information Service Report PB 82-168287, $34 \mathrm{p}$.

Sorg, D.H., and McLaughlin, R.J., 1975, Geologic map of the SargentBerrocal fault zone between Los Gatos and Los Altos Hills, Santa Clara County, California: U.S. Geological Survey Miscellaneous Field Studies Map MF-643, scale 1:24,000.

Stanley, R.G., 1987a, Effects of weathering on petroleum-source evaluation of coals from the Suntrana Formation near Healy, Alaska, in Hamilton, T.D., and Galloway, J.P., eds., Geologic studies in Alaska by the U.S. Geological Survey during 1986: U.S. Geological Survey Circular 998, p. 99-103.

1987b, New estimates of offset along the San Andreas fault based on paleobathymetry and paleogeography: Geology, v. 15, no. 2, p. 171-174.

-1990, Evolution of the Tertiary La Honda basin, central California, in Garrison, R.E., Greene, H.G., Hicks, K.R., Weber, G.E., and Wright, T.L., eds., Geology and tectonics of the central California coastal region, San Francisco to Monterey: Camarillo, Calif., American Association of Petroleum Geologists, Pacific Section Guidebook, v. 67, p. 1-29.

1995a, Central Coastal Province, California (011), in Gautier, D.L., Dolton, G.L., Takahashi, K.I., and Varnes, K.L., eds., U.S. Geological Survey 1995 national assessment of United States oil and gas resources-results, methodology, and supporting data: U.S. Geological Survey Digital Data Series DDS-30, 42 p.

1995b, Historical oil wells in Los Gatos, Santa Clara County, California: implications for tectonics, resources, and the environment [abs.]: American Association of Petroleum Geologists Bulletin, v. 79, no. 4, p. 598.

1995c, Northern Coastal Province, California (007), in Gautier, D.L., Dolton, G.L., Takahashi, K.I., and Varnes, K.L., eds., U.S. Geological Survey 1995 national assessment of United States oil and gas resources-results, methodology, and supporting data: U.S. Geological Survey Digital Data Series DDS-30, 35 p.

1995d, The "checkerboard method" - a new way to estimate the numbers of undiscovered hydrocarbon accumulations in sparselydrilled areas: U.S. Geological Survey Bulletin 2120, 8 p.

Stanley, R.G., Jachens, R.C., Kvenvolden, K.A., Hostettler, F.D., Magoon, L.B., and Lillis, P.G., 1996, Evidence for an oil-bearing sedimentary basin of probable Miocene age beneath "Silicon Valley," California [abs.]: American Association of Petroleum Geologists Annual Convention, San Diego, 1996, Official Program, v. 5, p. A133-A134.

Stanley, R.G., Jachens, R.C., Lillis, P.G., McLaughlin, R.J., Kvenvolden, K.A., Hostettler, F.D., and Magoon, L.B., 1998, Subsurface geology, Neogene tectonics, and petroleum of the southwestern Santa Clara Valley ("Silicon Valley"), California [abs.]: American Association of Petroleum Geologists Bulletin, v. 82, no. 5A, p. 859.

Sun Ge, Dilcher, D.L., Zheng Shaoling, and Zhou Zhekun, 1998, In search of the first flower-a Jurassic angiosperm, Archaefructus, from Northeast China: Science, v. 282, no. 5394, p. 1692-1695.

Tissot, B.P., and Welte, D.H., 1984, Petroleum formation and occurrence (2d ed.): Berlin, Springer-Verlag, 699 p.
Tolman, C.F., 1934, Bedrock conditions at proposed Vasona dam site, Santa Clara County, California: report to Santa Clara Valley Water Conservation District, $7 \mathrm{p}$.

Turner, D.L., 1970, Potassium-argon dating of Pacific Coast Miocene foraminiferal stages, in Bandy, 0.L., ed., Radiometric dating and paleontologic zonation: Geological Society of America Special Paper 124, p. 91-129.

Vander Leck, Lawrence, 1921, Petroleum resources of California, with special reference to unproved areas: California State Mining Bureau Bulletin 89, $186 \mathrm{p}$.

Vanderhurst, W.L., Cummings, J.C., and Andersen, D.W., 1982, The Santa Clara Formation as a record of late Cenozoic uplift of the Santa Cruz Mountains, Santa Clara County, California, in Ingersoll, R.V., and Woodburne, M.O., eds., Cenozoic nonmarine deposits of California and Arizona: Los Angeles, Society of Economic Paleontologists and Mineralogists, Pacific Section, p. 23-33.

Waples, D.W., 1985, Geochemistry in petroleum exploration: Boston, International Human Resources Development Corp., 232 p.

Watts, W.L., 1890, Santa Clara County: California State Mining Bureau Annual Report of the State Mineralogist 10, p. 604-619. 1900, Oil and gas yielding formations of California: California State Mining Bureau Bulletin 19, $236 \mathrm{p}$.

Weber, A.H., 1890, Santa Clara County: California State Mining Bureau Annual Report of the State Mineralogist 9, p. 48-56.

Wesson, R.L., Helley, E.J., Lajoie, K.R., and Wentworth, C.M., 1975, Faults and future earthquakes, in Borcherdt, R.D., ed., Studies for the seismic zonation of the San Francisco Bay region: U.S. Geological Survey Professional Paper 941-A, p. A5-A30.

Wilkinson, E.R., 1963, Hollister field: California Division of Oil and Gas Summary of Operations, California Oil Fields, v. 49, no. 1, p. 27-37.

1967, Hollister field, in Gabilan Range and adjacent San Andreas fault: Los Angeles, American Association of Petroleum Geologists-Society of Economic Paleontologists and Mineralogists, Pacific Sections, Field Trip Guidebook, p. 95-98.

Working Group on California Earthquake Probabilities, 1990, Probabilities of large earthquakes in the San Francisco Bay region, California: U.S. Geological Survey Circular 1053, 51 p.

\section{Appendix: Descriptions of Sample Localities in Miocene Sedimentary Rocks, Southwestern Santa Clara Valley and Vicinity}

[Sample localities are all in Santa Clara County, Calif. (figs. 4, 5)]

Sample: R1

Field No.: 11/9/95-6 (=Mf8982)

Latitude: $37.23367^{\circ} \mathrm{N}$.

Longitude: $121.97250^{\circ} \mathrm{W}$.

Formation: Monterey

Description: Shale, siliceous, light brown on broken surfaces, white-weathering, laminated, with phosphatic nodules, fish scales, and abundant microfossils. Strike and dip of bedding, N. $60^{\circ} \mathrm{W} ., 80^{\circ} \mathrm{N}$. From a natural exposure along the west bank of Los Gatos Creek near downtown Los Gatos, about $120 \mathrm{~m}$ downstream from the Roberts Road Bridge in sec. 16, T. 8 S., R. 1 W., Los Gatos 7.5-minute quadrangle. Elevation, about $96 \mathrm{~m}$. 
Sample: R2

Field No.: 11/9/95-7 (=Mf8983)

Latitude: $37.23367^{\circ} \mathrm{N}$.

Longitude: $121.97250^{\circ} \mathrm{W}$.

Formation: Monterey

Description: Shale, white-weathering, siliceous, with abundant microfossils. From the same outcrop as sample R1 (field No. 11/9/95-6).

Sample: R3

Field No.: 11/9/95-2

Latitude: $37.23333^{\circ} \mathrm{N}$.

Longitude: $121.97250^{\circ} \mathrm{W}$.

Formation: Monterey

Description: Mudstone, hard and brittle, dark-gray-brown on freshly broken surfaces, white-weathering, siliceous(?), with abundant microfossils. Strike and dip of bedding, N. $80^{\circ} \mathrm{E}$., vertical. From a natural exposure along the west bank of Los Gatos Creek near downtown Los Gatos, about 90 m downstream from the Roberts Road Bridge, in sec. 16, T. 8 S., R. 1 W., Los Gatos 7.5-minute quadrangle. Elevation, about 96 m.

Sample: R4

Field No.: 11/9/95-3 (=Mf8984)

Latitude: $37.23333^{\circ} \mathrm{N}$.

Longitude: $121.97250^{\circ} \mathrm{W}$.

Formation: Monterey

Description: Mudstone, brown on freshly broken surfaces, with abundant microfossils. From the same outcrop as sample R3 (field No. 11/9/95-2).

Sample: R5

Field No.: 97C-13 (=Mf9075)

Latitude: $37.22633^{\circ} \mathrm{N}$.

Longitude: $121.94033^{\circ} \mathrm{W}$.

Formation: Probable Monterey, but mapped as the Temblor

Formation by Bailey and Everhart (1964).

Description: Mudstone, hard, siliceous, white-weather-

ing, thin-bedded and laminated, with phosphatic nodules

and visible microfossils; interbedded with sandstone and

conglomerate. Strike and dip of bedding, N. $60^{\circ}$ E., $30^{\circ} \mathrm{S}$., overturned on the basis of normally graded beds of sandstone and conglomerate with scoured bases. From a roadcut along Shannon Heights Road in sec. 23, T. 8 S., R. 1 W., Los Gatos 7.5-minute quadrangle. Elevation, about $198 \mathrm{~m}$.

Sample: R6

Field No.: 97C-14 (=Mf9076)

Latitude: $37.22633^{\circ} \mathrm{N}$.

Longitude: $121.94033^{\circ} \mathrm{W}$.

Formation: Probable Monterey, but mapped as the Temblor

Formation by Bailey and Everhart (1964)

Description: From the same outcrop as sample R5 (field No. 97C-13), about 3 m stratigraphically below sample R5.

Sample: R7

Field No.: 11/1/95-3 (=Mf8974)
Latitude: $37.22700^{\circ} \mathrm{N}$.

Longitude: $121.92250^{\circ} \mathrm{W}$.

Formation: Monterey

Description: Shale, white-weathering, moderately hard, moderate to well-developed fissility, weak lamination, with fish scales, scattered microfossils, and phosphatic nodules; interstratified with subordinate beds of orange-weathering dolomite(?). Strike and dip of bedding, N. $45^{\circ}$ W., $35^{\circ} \mathrm{S}$. From a cut along a trail on Blossom Hill above Belgatos Park in sec. 24, T. 8S., R. 1 W., Los Gatos 7.5-minute quadrangle. Elevation, about $198 \mathrm{~m}$.

Sample: R8

Field No.: 11/1/95-4 (=Mf8975)

Latitude: $37.22467^{\circ} \mathrm{N}$.

Longitude: $121.92133^{\circ} \mathrm{W}$.

Formation: Monterey

Description: Shale, weathered and chalky, weakly fissile, with abundant fish scales and scattered microfossils; very hard, orange-weathering dolomite(?) concretion in float in nearby open grassy field. Strike and dip of bedding, N. $65^{\circ} \mathrm{W}$., $40^{\circ} \mathrm{N}$. From a cut along a trail on Blossom Hill, about $200 \mathrm{ft}$ from the trailhead at Sierra Azule Avenue in sec. 24, T. 8 S., R. 1 W., Los Gatos 7.5-minute quadrangle. Elevation, about 235 m.

Sample: R9

Field No.: 11/1/95-5 (=Mf8976)

Latitude: $37.22450^{\circ} \mathrm{N}$.

Longitude: $121.92167^{\circ} \mathrm{W}$.

Formation: Monterey

Description: Shale, white-weathering, moderately hard, fissile, with abundant microfossils; one orange-weathering dolomite(?) interbed, about $15 \mathrm{~cm}$ thick. Strike and dip of bedding, E.-W., $50^{\circ}$ N. From a shallow excavation for utilities on Blossom Hill at the intersection of Sierra Azule Avenue and Santa Rosa Avenue in sec. 24, T. 8 S., R. 1 W., Los Gatos 7.5minute quadrangle. Elevation, about $235 \mathrm{~m}$.

Sample: R10

Field No.: 11/3/95-2 (=Mf8978)

Latitude: $37.22283^{\circ} \mathrm{N}$.

Longitude: $121.94550^{\circ} \mathrm{W}$.

Formation: Monterey

Description: Porcelanite, white-weathering, laminated, with scattered microfossils. Strike and dip of bedding, N. $50^{\circ}$ E., $45^{\circ} \mathrm{S}$., probably overturned. From a roadcut along Hilltop Drive south of Shannon Road in sec. 23, T. 8 S., R. 1 W., Los Gatos 7.5-minute quadrangle. Elevation, about $219 \mathrm{~m}$.

Sample: R11

Field No.: 11/3/95-3 (=Mf8979)

Latitude: $37.22283^{\circ} \mathrm{N}$.

Longitude: $121.94467^{\circ} \mathrm{W}$.

Formation: Monterey

Description: Shale, white-weathering, moderately hard to brittle, fissile, with some laminated intervals and scattered to 
abundant microfossils; interbedded with sandstone, porcelanite, nonfissile siliceous mudstone, and one lens, about $1 \mathrm{~cm}$ thick, of glassy black chert. Strike and dip of bedding, N. $50^{\circ}-55^{\circ} \mathrm{E}$., $60^{\circ}-65^{\circ} \mathrm{S}$., overturned on the basis of normally graded sandstone beds with scoured bases. From a roadcut along Wooded View Drive south of Shannon Road in sec. 23, T. 8 S., R. 1 W., Los Gatos 7.5-minute quadrangle. Elevation, about $213 \mathrm{~m}$.

Sample: R12

Field No.: 11/2/95-1

Latitude: $37.07883^{\circ} \mathrm{N}$.

Longitude: $121.73533^{\circ} \mathrm{W}$.

Formation: Monterey

Description: Shale, dark-brown on fresh surfaces, whiteweathering, hard, laminated, with scattered fish scales; gradationally overlies friable, coarse-grained sandstone that contains abundant lithic grains. Strike and dip of bedding, N. $60^{\circ}$ E., $22^{\circ} \mathrm{S}$. From a roadcut along an unnamed dirt road near the Kozloff residence, south of Croy Road and west of the Uvas Reservoir, in the Croy Ridge area in sec. 10, T. 10 S., R. 2 E., Mount Madonna 7.5-minute quadrangle. Elevation, about $427 \mathrm{~m}$.

Sample: R13

Field No.: 11/2/95-2 (=Mf8977)

Latitude: $37.07533^{\circ} \mathrm{N}$.

Longitude: $121.74517^{\circ} \mathrm{W}$.

Formation: Monterey

Description: Shale, hard, laminated, brown on fresh surfaces, white-weathering, with scattered fish scales, possible microfossils, and phosphate nodules. From a roadcut along an unnamed dirt road south of Croy Road and west of Uvas Reservoir in the Croy Ridge area, near locality MSJ-131-88 of R.J. McLaughlin (unpub. data, 1988) in sec. 10, T. 10 S., R. 2 E., Mount Madonna 7.5-minute quadrangle. Elevation, about $469 \mathrm{~m}$.

Sample: R14

Field No.: 11/2/95-4

Latitude: $37.07533^{\circ} \mathrm{N}$.

Longitude: $121.74633^{\circ} \mathrm{W}$.

Formation: Monterey
Description: Shale, hard, brown, with phosphate nodules. From a roadcut along an unnamed dirt road south of Croy Road and west of the Uvas Reservoir at the "Indianwop Ranch" in the Croy Ridge area in sec. 10, T. 10 S., R. 2 E., Mount Madonna 7.5-minute quadrangle. Elevation, about $457 \mathrm{~m}$.

Sample: R15

Field No.: 11/2/95-3

Latitude: $37.07467^{\circ} \mathrm{N}$.

Longitude: $121.74700^{\circ} \mathrm{W}$.

Formation: Monterey

Description: Shale, hard, brown on fresh surfaces, laminated, siliceous(?). Strike and dip of bedding, N. $20^{\circ}$ W., $25^{\circ} \mathrm{SW}$. From a roadcut along an unnamed dirt road south of Croy Road and west of the Uvas Reservoir at the "Indianwop Ranch" in the Croy Ridge area in sec. 10, T. 10 S., R. 2 E., Mount Madonna 7.5-minute quadrangle. Elevation, about $469 \mathrm{~m}$.

Sample: R16

Field No.: 11/8/95-3 (=Mf8981)

Latitude: $37.01967^{\circ} \mathrm{N}$.

Longitude: $121.67617^{\circ} \mathrm{W}$.

Formation: Probable Monterey (unit Tsh of McLaughlin, 1971)

Description: Shale, brown, hard, with possible microfossils. From the side of a dirt road just northeast of Mount Madonna County Park and north of Sprig Lake in the unsectioned part of T. 10 S., R. 3 E., Mount Madonna 7.5-minute quadrangle. Elevation, $265 \mathrm{~m}$.

Sample: R17

Field No.: 11/8/95-2 (=Mf8980)

Latitude: $37.01950^{\circ} \mathrm{N}$.

Longitude: $121.67450^{\circ} \mathrm{W}$.

Formation: Probable Monterey (unit Tsh of McLaughlin, 1971)

Description: Shale, silty, dark-gray-brown. Strike and dip of bedding, N. $81^{\circ}$ W., $45^{\circ}$ N. From a ditch along a dirt road just northeast of Mount Madonna County Park and north of Sprig Lake in the unsectioned part of T. 10 S., R. 3 E., Mount Madonna 7.5-minute quadrangle. Elevation, about $226 \mathrm{~m}$. Same as locality 14 of McLaughlin (1971). 
TABLE 3 
Table 3.-Lithologic logs of oil wells in the Los Gatos area, southwestern Santa Clara County, California.

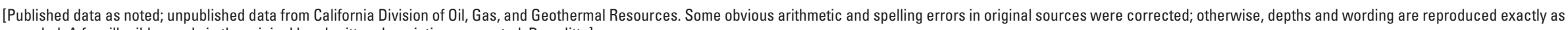
recorded. A few illegible words in the original handwritten descriptions are noted. Do.., ditto]

\begin{tabular}{|c|c|c|c|}
\hline $\begin{array}{c}\text { Top } \\
\text { (depth in } \mathrm{ft} \text { ) }\end{array}$ & $\begin{array}{c}\text { Bottom } \\
\text { (depth in } \mathrm{ft} \text { ) }\end{array}$ & $\begin{array}{l}\text { Thickness } \\
\text { (ft) }\end{array}$ & Description \\
\hline \multicolumn{4}{|c|}{$\begin{array}{c}\text { Main Estate Well No. } 1 \\
\text { [Total depth, } 754 \mathrm{ft} \text { (L.H. Eddy, in Watts, 1900, p. 153)] }\end{array}$} \\
\hline 0 & 30 & 30 & Coarse gravel. \\
\hline 30 & 50 & 20 & Sand and clay. \\
\hline 50 & 83 & 33 & Slate. \\
\hline 83 & 134 & 51 & Brown shale and gas (gas burned al top of well). \\
\hline 134 & 160 & 26 & Sand with oil. \\
\hline 160 & 170 & 10 & Hard shale (gas). \\
\hline 170 & 180 & 10 & Soft shale and a little sand with oil. \\
\hline 180 & 212 & 32 & Hard dark shale with oil. \\
\hline 212 & 260 & 48 & Granitic rock and shale. \\
\hline 260 & 285 & 25 & Black shale and oil. \\
\hline 285 & 290 & 5 & Hard shells. \\
\hline 290 & 300 & 10 & Shale with oil. \\
\hline 300 & 315 & 15 & Shelly formation with some oil. \\
\hline 315 & 340 & 25 & Dark shale. \\
\hline 340 & 390 & 50 & Lime rock. \\
\hline 390 & 400 & 10 & Brown shale. \\
\hline 400 & 410 & 10 & Sandy shale. \\
\hline 410 & 415 & 5 & Slate and iron pyrites. \\
\hline 415 & 422 & 7 & Hard gray sand and gas. \\
\hline 422 & 462 & 40 & Shale. \\
\hline 462 & 498 & 36 & Slate and streaks of hard shelly rock. \\
\hline 498 & 504 & 6 & Shale. \\
\hline 504 & 508 & 4 & Cavey formation. \\
\hline 508 & 513 & 5 & Sandy shale with strong flow of gas. \\
\hline 513 & 541 & 38 & $\begin{array}{l}\text { Slate. } \\
\text { Slats }\end{array}$ \\
\hline 541 & 565 & 24 & Soap rock. \\
\hline 565 & 580 & 15 & Slate. \\
\hline 580 & 590 & 10 & Sand rock. \\
\hline 590 & 620 & 30 & Sand and shale with more gas. \\
\hline 620 & 629 & 9 & Slate. \\
\hline 629 & 666 & 37 & Very soft slate. \\
\hline 666 & 680 & 14 & Hard streaks of slate. \\
\hline 680 & 754 & 74 & Slate. \\
\hline
\end{tabular}

\begin{tabular}{cccc}
\hline Top & $\begin{array}{c}\text { Bottom } \\
\text { (depth in } \mathrm{fl})\end{array}$ & $\begin{array}{c}\text { Thickness } \\
\text { (ft) }\end{array}$ & Description
\end{tabular}

Main Estate Well No. 2

[Total depth, $200 \mathrm{ft}$ (L.H. Eddy, in Wat1s. 1900, p. 153)]

$\begin{array}{rrrl}0 & 25 & 25 & \text { Gravel. } \\ 25 & 35 & 10 & \text { Sand. } \\ 35 & 78(?) & 43 & \text { Clay and litle streak of sand. } \\ 78(?) & 109 & 31 & \text { Sand. } \\ 109 & 119 & 10 & \text { Clay. } \\ 119 & 136 & 17 & \text { Brown shalc with heavy oil. } \\ 136 & 153 & 17 & \text { Brown shale and gas. } \\ 153 & 156 & 3 & \text { Sand. } \\ 156 & 162 & 6 & \text { Brown shale. } \\ 162 & 170 & 8 & \text { Shale mixed with green rock. }\end{array}$

Suburban Oil Co. Well No. 1-Continued

[Total depth, at least $2,750 \mathrm{ft}]$

\begin{tabular}{|c|c|c|c|}
\hline 1.285 & 1,315 & 30 & Brown shale, oil (water shut off, good show). \\
\hline 1.315 & 1,320 & 5 & Oil sand. \\
\hline 1,320 & 1,440 & 120 & Brown shale, showing lots of oil. \\
\hline 1,440 & 1.445 & 5 & Light brown shale. \\
\hline 1.445 & 1,495 & 50 & Brown shale, oil and gas. \\
\hline 1.495 & 1,520 & 25 & Hard brown shale, oil and gas. \\
\hline 1,520 & 1,525 & 5 & Light colored shalc. \\
\hline 1,525 & 1,540 & 15 & Gray oil sand, good. \\
\hline 1,540 & 1,600 & 60 & Brown sand and shells. \\
\hline 1.600 & 1,650 & 50 & Sofi brown shate. \\
\hline 1.650 & 1,670 & 20 & Hard brown shale. \\
\hline 1,670 & $1,8 \mathbf{2}$ & 150 & Blue shale (hole plugeed back to $1.804 \mathrm{ft}$ ). \\
\hline 1820 & 1.830 & 10 & Light brown shale ( $12 / 7 / 1 \mathrm{I}$, cemented). \\
\hline 1,830 & 1.840 & 10 & Sandy bluc shalc. \\
\hline 1.840 & 1.875 & 35 & Brown shale. \\
\hline 1,875 & 1,880 & 5 & Oil sand. \\
\hline 1,880 & 1,910 & 30 & Brown shale. \\
\hline 1,910 & 1,930 & 20 & Rotten shale. \\
\hline 1.930 & 1,935 & 5 & Hard shell. \\
\hline 1.935 & 2,000 & 65 & Sulfur water, flowed over pipe. \\
\hline 2.000 & 2,034 & 34 & Hard brown shalc, and black. \\
\hline 2.034 & 2,040 & 6 & Oil sand, gassy. \\
\hline 2,040 & 2,050 & 10 & Hurdd blue and brown shales. \\
\hline 2,050 & 2,060 & 10 & Sand rock, brown. \\
\hline 2,060 & 2,070 & 10 & Blue and brown shales. \\
\hline 2,070 & 2,095 & 25 & Black shale. \\
\hline 2.095 & 2,099 & 4 & Shell and sand in streaks. \\
\hline 2,099 & 2,110 & 11 & Blue shale. \\
\hline 2,110 & 2,190 & 80 & Dry sand, oil and gas. \\
\hline 2,190 & 2,210 & 20 & Conglomerate. \\
\hline 2.210 & 2,240 & 30 & Brown and blue shale. \\
\hline 2.240 & 2.260 & 20 & Sand rock [illegible words]. \\
\hline 2.260 & 2,280 & 20 & Blue clay. \\
\hline 2,280 & 2,285 & 5 & Hard sand. \\
\hline 2,285 & 2,305 & 20 & Bluc clay. \\
\hline 2,305 & 2,310 & 5 & Hard sand. \\
\hline 2.310 & 2.410 & 100 & Blue cliy. \\
\hline 2,410 & 2,440 & 30 & [Illegible wora]. \\
\hline 2,440 & 2,450 & 10 & Light colored sluale. \\
\hline 2,450 & 2.495 & 45 & Bluc clay, gas. \\
\hline 2,495 & 2,520 & 25 & Dry oil sand, gas. \\
\hline 2.520 & 2,560 & 40 & [IIlegible word] sand, gas and oil. \\
\hline 2,560 & 2,570 & 10 & Sandy shale, blue. \\
\hline 2,570 & 2,652 & 82 & Blue clay. \\
\hline 2.652 & 2.669 & 17 & Rich oil sand. \\
\hline 2,669 & 2,750 & 81 & Brown shale, oil. \\
\hline
\end{tabular}


El Capitan Well No. 1

[Total depth, at least 800 ft

Main Estate Well No. 3

[Total depth, at least 574 ff (L.H. Eddy, in Watts, 1900, p. 153)]

\begin{tabular}{rrrl}
\hline 0 & 30 & 30 & Sand and gravel. \\
30 & 112 & 82 & Green clay and thin stratum of brown shale. \\
112 & 141 & 29 & Coarse gravel and sand witl gas and heavy oil. \\
141 & 180 & 39 & Streaks of clay mixed with sand rock. \\
180 & 184 & 4 & Shale. \\
184 & 200 & 16 & Brown sand rock. \\
200 & 228 & 28 & Brown shale. \\
228 & 336 & 108 & Marl filled with sea shells. \\
336 & 345 & 9 & Brown shale. \\
345 & 406 & 61 & Mud streak. \\
406 & 437 & 31 & Soft brown shale. \\
437 & 478 & 41 & Very dark shell rock and salt water. \\
478 & 490 & 12 & Gray sand with strong flow of gas (at this depth. the \\
490 & 505 & 15 & Gas raised water over derrick). \\
505 & 520 & 20 & Dark sand and more rock filled with sea shells. \\
520 & 525 & 5 & Sand rock with asphaltum. \\
525 & 557 & 32 & Hard shale. \\
557 & 565 & 8 & Mud streak. \\
565 & 570 & 5 & Brown shale tull of oil. \\
570 & 574 & 4 & Brown shalc with more oil and gas.
\end{tabular}

Suburban Oil Co. Well No.

[Tolil depth, at least 2,750 ft]

$\begin{array}{rrl}40 & 40 & \text { Clay ind gravel. } \\ 45 & 5 & \text { Blue clay. } \\ 50 & 5 & \text { Oil sand. } \\ 60 & 10 & \text { Water sand. } \\ 140 & 80 & \text { Clay. } \\ 145 & 5 & \text { Sand. } \\ 155 & 10 & \text { Blue clay. } \\ 175 & 20 & \text { Dry sand. } \\ 185 & 10 & \text { Grawel. } \\ 210 & 25 & \text { Brown shale. } \\ 325 & 115 & \text { Shale. } \\ 332 & 7 & \text { Oil sand. } \\ 390 & 58 & \text { Light colored shale. } \\ 415 & 25 & \text { Brown shale. } \\ 420 & 5 & \text { Sand. } \\ 460 & 40 & \text { Brown shale. } \\ 470 & 10 & \text { Hard oil sand. } \\ 590 & 120 & \text { Hard brown shale, sulfur sand strong. } \\ 600 & 10 & \text { Brown shale. } \\ 930 & 330 & \text { Brown shale. } \\ 1,006 & 76 & \text { Water sand and shale (gassy). } \\ 1,008 & 2 & \text { Hard shale. } \\ 1,215 & 207 & \text { Brown shale. } \\ 1,230 & 15 & \text { Sand and shalc. } \\ 1,280 & 50 & \text { Brown shale (showing lots of oil). } \\ 1,285 & 5 & \text { Oil wand (water bailed out stoord } 18 \text { hours). }\end{array}$

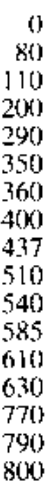
80
110
110
200
790$$
\begin{aligned}
& 290 \\
& 350 \\
& 360
\end{aligned}
$$$$
\begin{aligned}
& 360 \\
& 400 \\
& 437
\end{aligned}
$$$$
\begin{array}{r}
437 \\
510
\end{array}
$$$$
540
$$$$
\begin{aligned}
& 540 \\
& 585 \\
& 610
\end{aligned}
$$$$
610
$$$$
6.30
$$$$
770
$$

80
110

200
290
350

350

400

437

540

685

630

790

800$$
\begin{aligned}
& 790 \\
& 800
\end{aligned}
$$

No data

$\begin{array}{ll}80 & \text { Adobs. } \\ 30 & \text { Red siand. } \\ 90 & \text { Light red sand. } \\ 90 & \text { Light blue shale. } \\ 60 & \text { Ljght sandy shale. } \\ 10 & \text { Dark soft shale. } \\ 40 & \text { Oil sand. } \\ 37 & \text { Soft blue clay. } \\ 73 & \text { Yellow sandstone. } \\ 30 & \text { Light gray sandy shale. } \\ 45 & \text { Oil sand. } \\ 25 & \text { Very dark soft shalc. } \\ 20 & \text { Dirk shale. } \\ 140 & \text { Very rich oil sand. } \\ 20 & \text { Blue shate. } \\ 10 & \text { Heaving oil sand } \\ -- & \text { Blue sind. }\end{array}$

\section{Roanoke Oil Co. Well No. 1}

[Total dephl, at le:ist $1.017 \mathrm{ft}$ ]

$\begin{array}{rrrl}0 & 20 & 20 & \text { Surface. } \\ 20 & 70 & 50 & \text { Yellow sand. } \\ 70 & 104 & 34 & \text { Soft blue shale. } \\ 104 & 144 & 40 & \text { Ycllow sand. } \\ 144 & 270 & 126 & \text { Blue shale. } \\ 270 & 295 & 25 & \text { Brown sulfur. } \\ 295 & 315 & 20 & \text { Sulfur sand with traces of oil. } \\ 315 & 330 & 15 & \text { Soft blue sand shale. } \\ 330 & 356 & 26 & \text { Brown sand with oil, sulfur. } \\ 356 & 382 & 26 & \text { Blue shiale, soft. } \\ 382 & 450 & 68 & \text { Oil sand. } \\ 450 & 453 & 3 & \text { Shell. } \\ 453 & 860 & 407 & \text { Dark stale, sil traces all through this shale. } \\ 860 & 960 & 100 & \text { Dark shale, strong vein of gas it } 860 \text { rit. } \\ 960 & 1,017 & 57 & \text { Dark shalc. } \\ 1.017 & \text { No data } & -- & \text { Walter sund and gas. }\end{array}$

T.A.P. Oil Co. Well No.

[Total depth, 2,035 ft]

\begin{tabular}{rrrl}
\hline 0 & 80 & 80 & Surfacc. \\
80 & 225 & 145 & Yellow clay. \\
225 & 255 & 30 & Blue clay. \\
255 & 275 & 20 & Blue clay. \\
275 & 281 & 6 & Shell. \\
281 & 311 & 30 & Red rock. \\
311 & 355 & 44 & Sticky blue [shale?]. \\
355 & 360 & 5 & Browin shale. \\
360 & 380 & 20 & Sticky blue [shale?]. \\
380 & 390 & 10 & Oil sand. \\
390 & 433 & 43 & Blue clay. \\
433 & 445 & 12 & Oil sand.
\end{tabular}




$\begin{array}{ccc}\text { Top } & \text { Botton } \\ \text { (depth in } \mathrm{ft}) & \begin{array}{c}\text { Thickness } \\ (\mathrm{ft})\end{array} & \text { Description } \\ & & \end{array}$

T.A.P. Oil Co. Well No. 1-Continued

[Total depth, 2,035 ft]

\begin{tabular}{|c|c|c|c|}
\hline 445 & 485 & 40 & Blue clay sandy. \\
\hline 485 & 545 & 60 & Dark sandy shale. \\
\hline 545 & 550 & 5 & Hird shell. \\
\hline 550 & 635 & 85 & Dark sandy shalc. \\
\hline 635 & 6.38 & 3 & Hard shell. \\
\hline 638 & 685 & 47 & Dark sandy shalc. \\
\hline 685 & 689 & 4 & Hard shell. \\
\hline 689 & 762 & 73 & Brow'n wandy shale. \\
\hline 762 & 765 & 3 & $\begin{array}{l}\text { Hard shell. } \\
\text { Hotale. }\end{array}$ \\
\hline 765 & 785 & 20 & Brown shale. \\
\hline 785 & 800 & 15 & Sricky blue Ishale?]. \\
\hline 800 & 930 & 130 & $\begin{array}{l}\text { Hird brown shale. } \\
\text { Hell }\end{array}$ \\
\hline 930 & 940 & 10 & Sandy shale showing oil. \\
\hline 940 & 1.015 & 75 & Hard brown slate. \\
\hline 1.015 & 1.021 & 6 & H lard sand showing oil. \\
\hline I., 1 & 1,045 & 24 & Brown shale. \\
\hline I. 245 & 1,055 & 10 & Sandy shale showing oil. \\
\hline 1.055 & 1,060 & ${ }_{5}^{10}$ & Brown shalc. \\
\hline 1,60 & 1.105 & 45 & Hard brown shale and oil sand at base. \\
\hline 1,105 & $1,1,90$ & 45 & Brown shale and shells, water ftowed oyer pipe. \\
\hline 1.150 & 1.325 & 175 & Hard briswin shate. \\
\hline 1,325 & 1.350 & 25 & Brown shale. \\
\hline 1,350 & 1,352 & 2 & Shell. \\
\hline 1.352 & 1.370 & 18 & Oil sand and shalc, gas. \\
\hline 1,370 & 0.428 & 58 & Hard brown shale. oil. \\
\hline 1.428 & 1.432 & 4 & Shell. \\
\hline $1,4,32$ & 0,437 & 5 & Oil sand sond. \\
\hline 1.437 & 1,480 & 43 & $\begin{array}{l}\text { Brown shalc. } \\
\text { B. }\end{array}$ \\
\hline 1.480 & 1.487 & 7 & $\begin{array}{l}\text { Oi] sand, fine showing of oil. } \\
\text { Oines }\end{array}$ \\
\hline 1,487 & 1,500 & 13 & Blue clay. \\
\hline 1,500 & 1,505 & 5 & Oil sand, goodi? ? \\
\hline 3.505 & 1,524 & 19 & $\begin{array}{l}\text { Brown shale. } \\
\text { B. }\end{array}$ \\
\hline 1.524 & 1,530 & 6 & $\begin{array}{l}\text { Oij sand. } \\
\text { Oite. }\end{array}$ \\
\hline 1.530 & 1.575 & 45 & Brown shale. \\
\hline 1,575 & 1,600 & 25 & Light shale and oil sand. \\
\hline 1,600 & 1.634 & 34 & $\begin{array}{l}\text { Brown shale. } \\
\text { B. }\end{array}$ \\
\hline 1.634 & 0,646 & 12 & Oil sant, tlowed drilling water over pipe. \\
\hline$], 646$ & 1,660 & 14 & $\begin{array}{l}\text { Blue clay. } \\
\text {. }\end{array}$ \\
\hline 1,660 & 1,798 & 138 & $\begin{array}{l}\text { Brown shale. } \\
\text { Bum }\end{array}$ \\
\hline 1,798 & 1,804 & 6 & $\begin{array}{l}\text { Oil sand. } \\
\text { Oine. }\end{array}$ \\
\hline 1,804 & 1,860 & 56 & Blue shale. \\
\hline 1.860 & 1.866 & 6 & Oil sand. \\
\hline 1.866 & 1.912 & 46 & Dark blue shalc. \\
\hline 1.912 & 1.917 & 5 & Oi] sand. \\
\hline 1.917 & 1,930 & 13 & Brown blue clay. \\
\hline 1.930 & 1,935 & 5 & Oil sand. \\
\hline 1.935 & 1.955 & 20 & Blue and brown clay mixed with granire. \\
\hline 1,955 & 1.966 & 11 & $\begin{array}{l}\text { Blue clay, oil sand and slale. } \\
\text {. }\end{array}$ \\
\hline 1.966 & 1.974 & 8 & Oi] :andt? \\
\hline 1.974 & 1.990 & 16 & White sticky slole. \\
\hline 1.990 & 1.996 & 6 & Slicll. \\
\hline 1.996 & 2.035 & 39 & Whitish blue clay. \\
\hline
\end{tabular}

$\begin{array}{cccc}\text { Top } & \text { Bottom } \\ \text { (depth in } \mathrm{ft}) & \begin{array}{c}\text { Thickness } \\ \text { (ft) }\end{array} & \text { Description }\end{array}$

Traders Oil Corp. Well No. 1-Continued [Total depth, 2,006 ft]

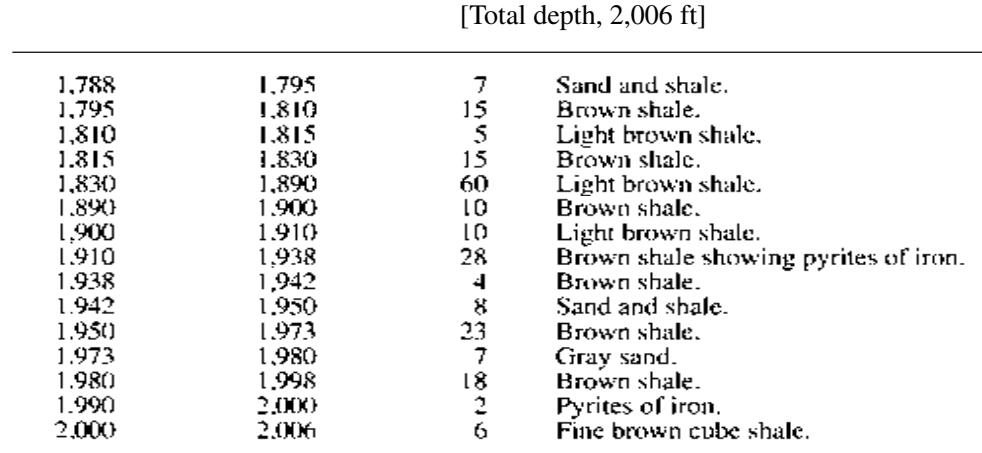

Traders Oil Corp. Well No. 2 (Rasmussen) [Total depth, $2.675 \mathrm{ft}$ ]

\begin{tabular}{|c|c|c|c|}
\hline 0 & & & \\
\hline 35 & $\begin{array}{r}35 \\
44\end{array}$ & 35 & $\begin{array}{l}\text { Boulders. } \\
\text { Hard onan }\end{array}$ \\
\hline 44 & 70 & 26 & $\begin{array}{l}\text { Hard pan. } \\
\text { Yellow clay. }\end{array}$ \\
\hline 70 & 75 & 5 & Sand. coarsc. \\
\hline 75 & 100 & 25 & Sedimentary yellow. \\
\hline 100 & 120 & 20 & $\begin{array}{l}\text { Allutial yellow. } \\
\text {. }\end{array}$ \\
\hline 120 & 123 & 3 & Water sand. \\
\hline 123 & 128 & 5 & Brown shale. \\
\hline 128 & 290 & 162 & Yellow shale. \\
\hline 290 & 314 & 24 & Light colored clay. \\
\hline 314 & 318 & 4 & Bjue clay. \\
\hline 318 & 321 & 3 & Gravel. \\
\hline 321 & 388 & 67 & Blue shale with gravel. \\
\hline 388 & 408 & 20 & Sticky shale. blue. \\
\hline $4(18$ & 411 & 3 & $\begin{array}{l}\text { Lighi shale. } \\
\text { Linte- }\end{array}$ \\
\hline 411 & 4.30 & 19 & Sticky light clay. \\
\hline 430 & 435 & 5 & $\begin{array}{l}\text { Blue shalc. } \\
\text { sity. }\end{array}$ \\
\hline 435 & 452 & 17 & Blue shale, sticky. \\
\hline 452 & 460 & 8 & $\begin{array}{l}\text { Blue shale. } \\
\text { Blity. }\end{array}$ \\
\hline 460 & 495 & 35 & Sticky blue shale with light colored streaks. \\
\hline 495 & 500 & 5 & Light colored shale. \\
\hline 50 & 510 & 10 & Sticky light clay. \\
\hline 510 & 560 & 50 & Bluc shale with hard streaks brown shale. \\
\hline 560 & 590 & 30 & Brown shale. \\
\hline 590 & 630 & 40 & Blue shale with streaks shell. \\
\hline 630 & 642 & 12 & Brown slale. \\
\hline 642 & 777 & 135 & Blue whale with shells. \\
\hline
\end{tabular}


Table 3.—Lithologic logs of oil wells in the Los Gatos area, southwestern Santa Clara County, California—Continued.

\begin{tabular}{|c|c|c|c|c|c|c|c|}
\hline \multicolumn{4}{|c|}{$\begin{array}{l}\text { Traders Oil Corp. Well No. } 1 \\
\text { [Total depth, 2,006 ft] }\end{array}$} & \multirow{2}{*}{$\begin{array}{l}777 \\
785 \\
880 \\
902 \\
928 \\
935\end{array}$} & \multirow{2}{*}{$\begin{array}{l}785 \\
880 \\
902 \\
928 \\
935 \\
948\end{array}$} & \multirow{2}{*}{$\begin{array}{r}8 \\
95 \\
22 \\
26 \\
7 \\
13\end{array}$} & \multirow{2}{*}{$\begin{array}{l}\text { Brown shale. } \\
\text { Blue shale with shells. } \\
\text { Brown shale. } \\
\text { Light colored shale. } \\
\text { Sandy shale. } \\
\text { Tough blue shale. }\end{array}$} \\
\hline 0 & 35 & 35 & Sand and gravel. & & & & \\
\hline 35 & 43 & 8 & Hard pan. & & & 40 & Tough brown shale, very sticky. \\
\hline $\begin{array}{l}35 \\
43\end{array}$ & $\begin{array}{r}43 \\
110\end{array}$ & $\begin{array}{r}8 \\
67\end{array}$ & $\begin{array}{l}\text { Hard pan. } \\
\text { Yellow clay with indications of seepage water. }\end{array}$ & 988 & 1,265 & 277 & Blue shale with brown streaks and hard streaks. \\
\hline 110 & 145 & 35 & $\begin{array}{l}\text { Yellow clay with indications or seepage water. } \\
\text { Blue clay. }\end{array}$ & 1,265 & 1,408 & 143 & Brown shale with hard streaks through it. \\
\hline 145 & 160 & 15 & Yellow clay and gravel. & 1,408 & 1,422 & 14 & Light brown sandy shale with light traces oil. \\
\hline 160 & 165 & 5 & $\begin{array}{l}\text { Blue clay. } \\
\text { clin graver. }\end{array}$ & 1,422 & 1,436 & 14 & Brown shale. \\
\hline 165 & 173 & 8 & Water sand. & 1,436 & 1,450 & 14 & Sandy shale. \\
\hline 173 & 280 & 107 & Blue clay, sandy. & 1,450 & 1,461 & 11 & Hard brown shale. \\
\hline 280 & 610 & 330 & $\begin{array}{l}\text { Biue clay, sandy. } \\
\text { Brown shale }\end{array}$ & 1,461 & 1,464 & 3 & Sticky brown sandy shale. \\
\hline 610 & 612 & 300 & $\begin{array}{l}\text { Brown snale } \\
\text { Shell. }\end{array}$ & 1,464 & 1,483 & 19 & Sandy shale. \\
\hline 612 & 650 & 38 & $\begin{array}{l}\text { Shell. } \\
\text { Light brown shale, light showing of oil. }\end{array}$ & 1,483 & 1,673 & 190 & Brown shale with hard shells. \\
\hline 650 & 690 & 40 & Hard brown shale. & 1,673 & 1,677 & 4 & $\begin{array}{l}\text { Conglomerate gravel. } \\
\text { Clinecis. }\end{array}$ \\
\hline 690 & 715 & 25 & Very hard sandy blue clay showing little oil. & 1,677 & 1,918 & 241 & Brown shale with shells through it. \\
\hline 715 & 730 & 15 & $\begin{array}{l}\text { Brown shale. } \\
\text { B. }\end{array}$ & 1,918 & 1,928 & 10 & Brown sandy shale with trace of oil. \\
\hline 730 & 740 & 10 & $\begin{array}{l}\text { Brown snale. } \\
\text { Hard light brown shell. }\end{array}$ & 1,928 & 1,937 & 9 & Soft brown shale with hard streaks in it. \\
\hline 740 & 845 & 105 & Brown shale and sand showing very little oil and gas. & 1,937 & 1,968 & 31 & Sandy shale with trace of oil and gas through it. \\
\hline 845 & 860 & 15 & $\begin{array}{l}\text { Brown shale, some showing oil. } \\
\text { Hard shale }\end{array}$ & 1,968 & 2,048 & 80 & Brown shale. \\
\hline 860 & 870 & 10 & $\begin{array}{l}\text { Sand, showing some oil and gas. } \\
\text { Sand }\end{array}$ & 2,048 & 2,067 & 19 & Brown shale with trace of oil and gas. \\
\hline 870 & 910 & 40 & $\begin{array}{l}\text { Sand, showing some oil and gas. } \\
\text { Blue clay. }\end{array}$ & 2,067 & 2,128 & 61 & Brown shale. \\
\hline 910 & 935 & 25 & Hard shale. & 2,128 & 2,131 & 3 & Hard shell. \\
\hline 935 & 941 & 6 & $\begin{array}{l}\text { Hard snack. } \\
\text { Hard rock. }\end{array}$ & 2,131 & 2,180 & 49 & Brown shale, tough, loads up on bit. \\
\hline 941 & 948 & 7 & $\begin{array}{l}\text { Hard rock. } \\
\text { Brown shale. }\end{array}$ & 2,180 & 2,182 & 2 & Light colored shale, streaks brown. \\
\hline 948 & $\begin{array}{l}948 \\
952\end{array}$ & 4 & $\begin{array}{l}\text { Shell. } \\
\text { Shale. }\end{array}$ & 2,182 & 2,254 & 72 & Brown tough shale, loads up on bit badly. \\
\hline 952 & 980 & 28 & $\begin{array}{l}\text { Shell. } \\
\text { Sandy blue clay. }\end{array}$ & 2,254 & 2,340 & 86 & Dark colored shale with shells, showing oil and gas. \\
\hline 980 & 983 & 3 & Shell. & 2,340 & 2,345 & 5 & 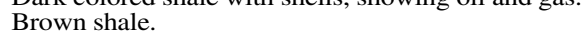 \\
\hline 983 & 987 & 4 & Sand. & 2,345 & 2,413 & 68 & Brown shale. \\
\hline 987 & 989 & 2 & Shell. & 2,413 & 2,417 & 4 & Light colored tough clay, drills slow. \\
\hline 989 & 1,025 & 36 & Blue clay. & 2,417 & 2,431 & 14 & Brown shale. \\
\hline 1,025 & 1,110 & 85 & Brown shale showing little oil. & 2,431 & 2,437 & 6 & Brown shale. \\
\hline 1,110 & 1,117 & 7 & $\begin{array}{l}\text { Brown shale showing little oil. } \\
\text { Blue clay. }\end{array}$ & 2,437 & 2,535 & 98 & Brown shale. \\
\hline 1,117 & 1,176 & 59 & $\begin{array}{l}\text { Bute clay. } \\
\text { Brown shale. }\end{array}$ & 2,535 & 2,539 & 4 & Light brown shale. \\
\hline 1,176 & 1,182 & 6 & Shell. & 2,539 & 2,542 & 3 & Dark brown shale with shells. \\
\hline 1,182 & 1,292 & 110 & Sticky clay & 2,542 & 2,578 & 36 & Brown shale with trace oil. \\
\hline 1,292 & 1.297 & 5 & Hard shale. & 2,578 & 2,595 & 17 & Brown shale. \\
\hline 1,292 & 1,321 & 24 & Blue clay. & 2,595 & 2,598 & 3 & Hard shale. \\
\hline 1,321 & $\begin{array}{l}1,321 \\
1,326\end{array}$ & $\begin{array}{r}24 \\
5\end{array}$ & $\begin{array}{l}\text { Blue sand. } \\
\text { Blue sand }\end{array}$ & 2,598 & 2,675 & 77 & Brown shale. \\
\hline 1,326 & 1,506 & 180 & Blue clay. & & & & \\
\hline 1,506 & 1,533 & 27 & Brown shale. & & & & \\
\hline 1,533 & 1,571 & 38 & $\begin{array}{l}\text { Blue clay. } \\
\text { Blues }\end{array}$ & & & Carl C & sen Well No. 1 \\
\hline 1,571 & 1,608 & 37 & Brown shale. & & & To & lepth, $615 \mathrm{ft}$ \\
\hline 1,608 & 1,656 & 48 & Sandy clay. & & & & \\
\hline 1,656 & 1,671 & 15 & Hard shell. & & & & \\
\hline 1,671 & 1,717 & 46 & Brown shale. & 0 & 45 & 45 & Clay and boulders. \\
\hline 1,717 & 1,721 & 4 & Brown shale. & 45 & 65 & 20 & Blue shale. \\
\hline 1,721 & 1,727 & 6 & Light brown shale. & 65 & 70 & 5 & Hard dry sand. \\
\hline 1,727 & 1,730 & $\begin{array}{l}0 \\
3\end{array}$ & $\begin{array}{l}\text { Pyrites of iron. } \\
\text { P. }\end{array}$ & 70 & 150 & 80 & Sticky blue shale. \\
\hline 1,730 & 1,740 & 10 & Blue sand and shale. & 150 & 171 & 21 & Light blue clay, very sticky. \\
\hline 1,740 & 1,753 & 13 & $\begin{array}{l}\text { Blue shale. } \\
\text { Blue snale. }\end{array}$ & 171 & 196 & 25 & Blue clay. \\
\hline 1,753 & 1,755 & 2 & Shell. & 196 & 590 & 394 & Sandy brown shale showing very little oil. \\
\hline 1,755 & 1,765 & 10 & Blue sand. & 590 & 595 & 5 & Black slate. \\
\hline 1,765 & 1,772 & 7 & Sand and shale. & 595 & 605 & 10 & Sticky brown shale. \\
\hline 1,772 & 1,780 & 8 & Blue shale. & 605 & 615 & 10 & Water sand. \\
\hline 1,780 & 1,788 & 8 & Brown shale. & & & & \\
\hline
\end{tabular}

